\title{
Cyclosporine therapy for psoriasis : how to improve the risk-benefit ratio
}

Citation for published version (APA):

Korstanje, M. J. (1993). Cyclosporine therapy for psoriasis : how to improve the risk-benefit ratio. [Doctoral Thesis, Maastricht University]. Thesis Publishers. https://doi.org/10.26481/dis.19930408mk

Document status and date:

Published: 01/01/1993

DOI:

10.26481/dis.19930408mk

Document Version:

Publisher's PDF, also known as Version of record

\section{Please check the document version of this publication:}

- A submitted manuscript is the version of the article upon submission and before peer-review. There can be important differences between the submitted version and the official published version of record.

People interested in the research are advised to contact the author for the final version of the publication, or visit the DOI to the publisher's website.

- The final author version and the galley proof are versions of the publication after peer review.

- The final published version features the final layout of the paper including the volume, issue and page numbers.

Link to publication

\footnotetext{
General rights rights.

- You may freely distribute the URL identifying the publication in the public portal. please follow below link for the End User Agreement:

www.umlib.nl/taverne-license

Take down policy

If you believe that this document breaches copyright please contact us at:

repository@maastrichtuniversity.nl

providing details and we will investigate your claim.
}

Copyright and moral rights for the publications made accessible in the public portal are retained by the authors and/or other copyright owners and it is a condition of accessing publications that users recognise and abide by the legal requirements associated with these

- Users may download and print one copy of any publication from the public portal for the purpose of private study or research.

- You may not further distribute the material or use it for any profit-making activity or commercial gain

If the publication is distributed under the terms of Article $25 \mathrm{fa}$ of the Dutch Copyright Act, indicated by the "Taverne" license above, 


\section{CYCLOSPORINE THERAPY FOR PSORIASIS}

How to improve the risk-benefit ratio. 


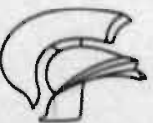

THESIS PUBLISHERS

AMSTERDAM 1993

CIP-DATA KONINKLIJKE BIBLIOTHEEK, DEN HAAG

Korstanje,M.J.

Cyclosporine therapy for psoriasis: How to improve the risk benefit ratio/ M.J. Korstanje. - Amsterdam: Thesis Publishers

Thesis Maastricht. - With ref. - With summary in Dutch. ISBN 90-5170-193-4

NUGI 742

Subject headings: psoriasis / renal function 


\section{CYCLOSPORINE THERAPY FOR PSORIASIS}

How to improve the risk-benefit ratio

\section{PROEFSCHRIFT}

ter verkrijging van de graad van doctor aan de Rijksuniversiteit Limburg, op gezag van de Rector Magnificus, Prof.mr. M.J. Cohen, volgens het besluit van het College van Dekanen, in het openbaar te verdedigen op donderdag 8 april 1993 om 16.00 uur

door

MARINUS JAN KORSTANJE

geboren te Goes 
Promotores: $\quad$ Prof.Dr. W.J.B.M. van de Staak

Prof.Dr. Th.M. Starink

Beoordelingscommissie: Prof.Dr. P.J.C. van Breda Vriesman (voorzitter)

Prof.Dr. J.W. Arends

Dr. H.J.G.Bilo

Prof.Dr. R.A. Janknegt

Dr. T.J. Stoof

Financial support for the printing of this thesis was provided by the following pharmaceutical industries; Sandoz, Lederle, Glaxo, Leo and Brocades Pharma. 
VOOR MIJN OUDERS 
CONTENTS

LIST OF ABBREVIATIONS

$\begin{array}{ll}\text { PREFACE } & 10\end{array}$

$\begin{array}{lll}\text { PART I INTRODUCTION } & 13\end{array}$

Psoriasis 15

Therapeutic possibilities in psoriasis 19

Effects of cyclosporine on immunologic mechanisms in psoriasis 30

Indications for cyclosporine other then psoriasis and atopic dermatitis 34

References $\quad 40$

PART II EFFICACY OF CYCLOSPORINE THERAPY FOR PSORIASIS AND ATOPIC DERMATITIS

CHAPTER I Long-term treatment of psoriasis with cyclosporine A; Sideeffects, minimal effective dose and cyclosporine bloodlevels

CHAPTEK 2 rustular psoriasis and aurodomatitis continua (Ilallopcau) need high doses of systemic cyclosporine $\mathrm{A}$.

CHAPTER 3 Cyclosporine maintenance therapy for severe atopic dermatitis.

PART III HOW TO IMPROVE THE RISK-BENEFIT RATIO OF CYCLOSPORINE THERAPY FOR PSORIASIS

CHAPTER I Introduction

CHAPTER 2 Dose-regimens

CHAPTER 3 Combination with other therapies for psoriasis

3.1 Combination therapy cyclosporine A-PUVA in psoriasis

3.2 Combination-therapy cyclosporine-A-etretinate for psoriasis

3.3 Cyclosporine and methotrexate: A dangerous combination 
PART IV RENAL FUNCTION LOSS AFTER CYCLOSPORINE MAINTENANCE THERAPY FOR PSORIASIS

CHAPTER $I$ Introduction 81

CHAPTER 2 Assessinent of renal function and renal function changes 84 during cyclosporine treatiment.

CHAPTER 3 Sustained renal function loss in psoriasis patients after 93 withdrawal of low-dose cyclosporine therapy.

CHAPTER 4 Does fish oil protect renal function in cyclosporine treated 99 psoriasis patients?

SUMMARY

$\begin{array}{ll}\text { SAMENVATTING } & 109\end{array}$

DANKWOORD $\quad 110$

CURRICULUM VITAE $\quad 112$

FURTHER PUBLICATIONS 113 



\section{ABBREVIATIONS}

APC Antigen Presenting Cell

Cock Cockroft formula (see page 113)

Creat Creatinine

CsA Cyclosporine

CTL Cytotoxic T lymphocyte

DHA Docosahexaenoic acid

EPA Eicosapentaenoic acid

ERPF Effective renal plasma flow (see page 134)

GFR Glomerular filtration rate (see page 134)

GM-CSF Granulocyte-macrophage colony stimulating factor

ICAM Intercellular adhesion molecule

IL Interleukin

IP3 Inositol 1,4,5 triphosphate

MAP Mean arterial pressure (see page 134)

MED Minimal effective dose

MHC Major histocompatibility complex

MTX Methotrexate

NS Not significant

PASI Psoriasis Area and Severity Index (see page 71)

RBF Renal blood flow (see page 134)

RIA Radio immunoassay

SCr Serum creatinine

SD Standard deviation

S.e.m Standard error of the mean

TNF Tumor Necrosis Factor

TRVR Total renal vascular resistance (see page 134)

TxA2 Thromboxane A2

UVB Ultraviolet $B$

PUVA Psoralens + ultraviolet A

Re-PUVA Retinoids + PUVA 


\section{PREFACE}

The first part of this thesis consists of reviews of the literature about the clinical features, histopathology, and the therapeutic modalities for psoriasis. The effects of cyclosporine on the immunologic mechanisms in psoriasis and other indications for cyclosporine in the field of dermatology, other then psoriasis or atopic dermatitis, are discussed as well. Research in psoriasis has been rapidly expanding over the past decade. Large textbooks are available about psoriasis alone and our knowledge about the pathogenesis seems never up to date. Therefore, the introduction in this thesis can not be a complete overview about every aspect of psoriasis nor a summary of the latest developments. It simply intends to give a brief impression about psoriasis and its therapies, for those who are not familiar with the disease. Without this knowledge about psoriasis it is impossible to understand the importance of cyclosporine or its important place in the therapeutic arsenal for severe psoriasis.

Part II consists of two studies and a case report. 'This part of the thesis is focussed on the effectiveness of cyclosporine in the treatment of psoriasis, pustular psoriasis and atopic dermatitis. We report, for the first time, that cyclosporine is highly effective for the treatment of atopic dermatitis. Atopic dermatitis is after psoriasis the most important indication for cyclosporine therapy in dermatology. Cyclosporine is one of the most potent drugs for the treatment of psoriasis and atopic dermatitis. However, its use is limited by side-effects.

In Part III the results of studies with dose regimens and combination therapies between cyclosporine and conventional therapies for psoriasis are discussed. The combination therapies were studied to find a way to improve the effectiveness of the cyclosporine therapy with diminished risk for side-effects.

The most important side-effect of cyclosporine, renal function loss, is discussed separately in Part IV. In the introduction the possible pathomechanisms for the cyclosporine induced renal function loss are discussed in a review of the available literature. Further, the accuracy of serum creatinine and the calculated creatinine clearance in relation to the golden standard, the glomerular filtration rate, is discussed. The data used in this article were obtained from our psoriasis patients, and from healthy volunteers and renal 
transplant recipients treated by Dr.J.J.Homan van der Heide in Groningen. The calculated creatinine clearance (Cockroft) is propagated in the literature, but has its own limitations. The use of cyclosporine is limited by side-effects, mainly renal function loss. A search for ways to prevent renal function loss is warranted. A combination therapy with a drug that has an influence on the pathogenesis of the cyclosporine-induced renal function loss seems necessary. Fish oil, in theory, has the potential to prevent renal function loss. In our pilot-study presented in this thesis and in publications by others fish oil seems to be promising.

Continuing research is necessary to improve the cyclosporine therapy. This thesis made clear that the solution can not be found in dose-regimens or combination therapies with existing therapies for psoriasis. A combination therapy with a drug that can influence the pathogenesis of the cyclosporine-induced renal function loss is necessary. Fish oil seems to be very promising. But other interesting drugs for further research are becoming availble. This thesis is therefore no more then a short moment in a continuing process of research, further development and improvement of cyclosporine therapy and the management of psoriasis. 


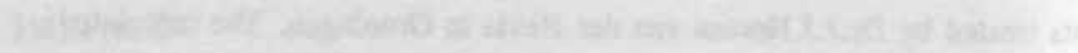

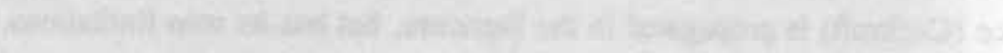

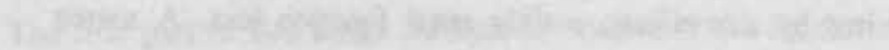

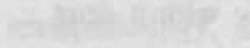

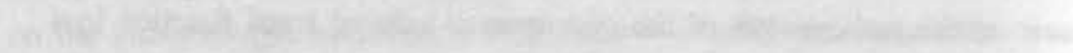

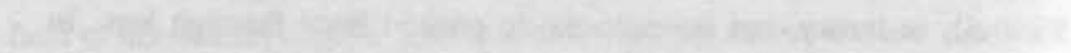

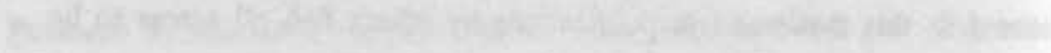

$=2$

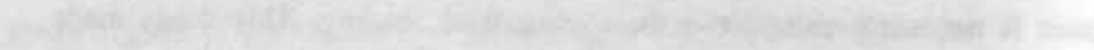

and

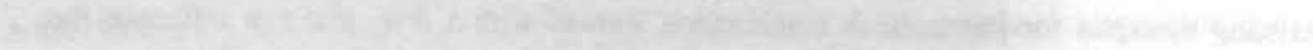

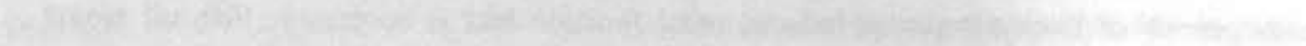

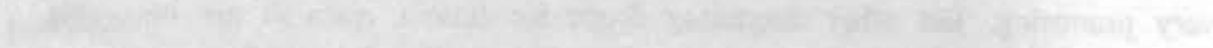

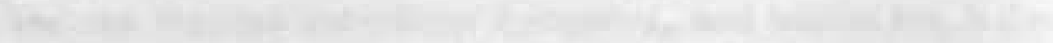

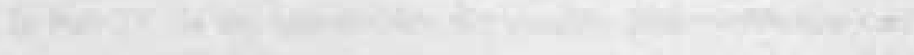




\section{PART I INTRODUCTION}





\section{PSORIASIS '}

Psoriasis is a genetically determined chronic disease of the skin with a prevalence of $1.5 \%$ in north-west European adults. The skin lesions are characterized by the presence of sharply demarcated, dull-red scaly plaques, particularly on extensor prominences and on the scalp. The disease is variable in duration and extent. Morphological variants are common.

Psoriasis may be divided into psoriasis vulgaris, in which pustules are absent; generalized pustular psoriasis; and localized pustular psoriasis. Psoriasis vulgaris includes psoriasis vulgaris en plaque, guttate psoriasis, nummular psoriasis and flexural psoriasis. Generalized pustular psoriasis includes the von Zumbusch type and, as variants, generalized acrodermatitis continua of Hallopeau (acral type of generalized pustular psoriasis) and impetigo herpetiformis (exanthematous type of generalized pustular psoriasis). There are three types of localized pustular psoriasis: 1. "psoriasis with pustules" in which only one or a few areas of psoriasis show pustules and the tendency to develop into a generalized pustular psoriasis is not great; 2. localized acrodermatitis continua of Hallopeau, which occasionally changes into generalized acrodermatitis continua; and 3 . pustular psoriasis of the palms and soles, also called pustulosis palmaris et plantaris, which occasionally is seen in association with psoriasis vulgaris. Severe exacerbations of all types of psoriasis may cause erythrodermia.

\section{Psoriasis vulgaris}

Psoriasis vulgaris en plaque is characterized by brownish red plaques predominantly on the extensor surface of knees and elbows, the scalp and in the sacral region. Psoriasis guttata describes a shower of small lesions, appearing more or less generally over the body. Nummular psoriasis describes discs and small plaques varying in size on the limbs and trunk and in flexural psoriasis the groins, axillae, submammary areas and other body folds are affected. The psoriatic lesions are sharply demarcated, dry, and usually covered with layers of silvery scales. As the scales are removed by gentle scraping, fine bleeding points usually are seen, the so called Auspitz sign. The scalp, sacral region, and extensor surfaces of the extremities are commonly involved, although, in some patients, the flexural and intertriginous areas are mainly affected. Involvement of the nails is common. In severe cases, the disease may affect the entire skin and present itself as generalized 
erythrodermic psoriasis. Pustules generally are absent in psoriasis vulgaris, although pustular psoriasis of the palms and soles occasionally occurs. Rarely, one or a few areas show pustules. Also rarely, severe psoriasis vulgaris develops into generalized pustular psoriasis. Oral lesions do not occur in psoriasis vulgaris but may be seen in generalized pustular psoriasis.

Psoriatic arthritis characteristically involves the terminal interphalangeal joints, but, not frequently, the large joints are also affected, so that a clinical differentiation from rheumatoid arthritis often is impossible.

\section{Generalized pustular psoriasis}

Basically, generalized pustular psoriasis of von Zumbusch, acrodermatitis continua of Hallopeau, and impetigo herpetiformis represent the same disease process. There is considerable resemblance and overlapping in the clinical picture of these three diseases, and they share similar histologic features. They differ mainly in mode of onset and in distribution of the lesions. Clinically, all three diseases show groups of shallow pustules on an erythematous base, and all three quite frequently show oral pustules, particularly on the tongue. Sudden exacerbations in association with chills and fever occur in all three

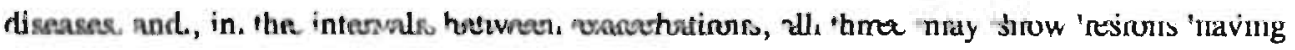
the clinical appearance of psoriasis.

Acrodermatitis continua of Hallopeau is the term used if the pustular eruption involves the distal portions of the hands and feet. In the localized type of acrodermatitis continua these are the only areas affected, while in the generalized type of acrodermatitis continua extensive areas of the skin are involved in addition to the distal portions of the hands and feet. On the fingers and toes, atrophy of the skin and permanent loss of the nails may occur.

Pustular psoriasis of von Zumbusch is generally diagnosed when the pustular eruption occurs in patients with preexisting psoriasis either of the plaque type or of the erythrodermic type.

Impetigo herpetiformis is diagnosed when the disease starts suddenly without any preceding lesions of psoriasis as an extensive eruption of pustules on an erythematous base. In some instances, the lesions are annular or gyrate and show a clinical resemblance to subcomeal pustular dermatosis. Annular pustular psoriasis, though usually generalized, in some instances is localized. 


\section{Localized pustular psoriasis}

This may be "psoriasis with pustules", localized acrodermatitis continua of Hallopeau, localized annular pustular psoriasis or pustulosis palmaris et plantaris.

Pustulosis palmaris et plantaris, is a chronic, relapsing disorder occurring on either the palms or the soles or both. Crops of small, deep-seated pustules are seen within areas of eryhtema and scaling. In the earliest stage, the lesions may appear as vesicles or vesicopustules. During the subsiding stage, the pustules appear as brown macules. The sites of predilection are the midpalms and thenar eminences of the hands, and the heels and insteps of the feet. In pustulosis palmaris et plantaris, in contrast to acrodermatitis continua of Hallopeau, the acral portions of the fingers and toes are spared.

\section{HISTOPATHOLOGY ${ }^{2}$}

Classical psoriatic lesions show marked and characteristic acanthosis of the epidermal ridges, which are evenly elongated and club-shaped at their bases, alternating with long cedematous papillae which are club-shaped at their tips. The suprapapillary plate is thinned and the epidermal surface is covered by alternating layers of hyperkeratosis and parakeratosis. Large tortuous capillaries are present in the papillary dermis and there is a slight perivascular lymphocytic infiltrate in the subpapillary dermis. Diagnostic features of active lesions include the 'Munro microabscess' and spongiform pustules. Munro microabscesses represent an accumulation of polymorphs in the stratum corneum. Mainly neutrophils migrate into the suprapapillary plate and then aggregate in the parakeratotic mould to form a microabscess. Spongiform pustules are seen beneath the parakeratotic stratum corneum and consist of small accumulations of neutrophils intermingled with the epidermal cells.

In pustular psoriasis the histologic picture is slightly different in that the spongiform pustule occurs as a macropustule and is the characteristic lesion. With increase in size of the spongiform pustules, death of the epidermal cells occurs with resulting central cavitation. At the edges a shell of thinned epidermal cells remains. Eventually there is migration of neutrophils into the horny layer such that the picture resembles that of a large Munro abscess. Otherwise the epidermal and dermal features are similar to those of psoriasis vulgaris. 


\section{AETIOLOGY}

Several large population studies have demonstrated marked familial aggregation of psoriasis. The absence of spouse aggregation excludes an environmental explanation. Therefore the genetic basis of psoriasis is indisputable. ${ }^{3}$ The mode of inheritance is not known. There is no evidence for single-gene dominant, sex-limited or sex-linked inheritance. It has been suggested that psoriasis is caused by interaction of multiple genes. Several factors are important since they may provoke psoriasis. Psoriasis may appear 7 to 14 days after an injury, operation incision or at the site of a scratsch. It is well known that streptococcal infections, especially in the throat, may provoke acute guttate psoriasis. Sunlight is generally beneficial, but a very small minority of psoriatics are provoked by sunlight and suffer summer exacerbation in exposed skin. Drugs as e.g. antimalarials, beta-adrenergic blocking agents and lithium may exacerbate psoriasis and may even provoke a generalized exfoliative form of psoriasis. Emotional stress may be a trigger and perpetuating factor. 


\section{THERAPEUTIC POSSIBILITIES IN PSORIASIS}

In the last decade the therapeutic possibilities for psoriasis have increased substantially. Few therapies are still in an experimental stage. However, the results of these therapies are promising and their use in clinical practice in the near future seems to be likely. The therapeutic possibilities including the new therapies in psoriasis are reviewed and listed below.

\section{COAL TAR (Pix Lithantracis, Sol. Carbo Detergens)}

The colour (grey-brown to black) and the unpleasant smell make this therapy not very acceptable to the patient. The effectiveness is moderate. Therefore, coal tar is not used regularly as a monotherapy for psoriasis.

Coal tar is used in combination with dithranol. An additional effect to the effect of ditranol is assumed and the irritation of the skin due to dithranol therapy may be partially prevented. However, in a recent study " neither an additional effect of coal tar on psoriasis nor a beneficial effect on skin irritation in dithranol therapy was found. In another study a decrease in skin irritation was observed. ${ }^{5}$ The oxidation of dithranol is enhanced by coal tar which may reduce the skin irritation and activity of the dithranol. ${ }^{6}$ Coal tar is also used in combination with light therapy in the form of ultraviolet-B (UV-B) (Goeckerman therapy). Coal tar is only effective when suberythemogenic doses of UV-B are used. There is no additional effect of coal tar when erythematogenic dosis UV-B are used. ${ }^{7}$

Coal tar may induce phototoxic reactions, folliculitis or acne-like skin changes. Coal tar is mutagenic and induces DNA changes after application on the skin. ${ }^{8}$ When large skin areas are treated with coal tar, cytogenitical changes in lymphocytes are detectable in blood." Further, mutagenic metabolites are detectable in urine. ${ }^{10}$ This suggests a risk of malignant changes in the skin or elsewhere in the body. In few studies the carcinogenic potency of coal tar was shown," but in other studies no evidence of a carcinogenic potency was found. ${ }^{12,13}$ In a case-control study ${ }^{14}$ an increased risk of skin cancer was detected in the combination therapy coal tar-UVB and in the combination therapy coal tar-psoralens in combination with ultraviolet A light (PUVA).

\section{DITHRANOL}

Dithranol and related substances have been used in psoriasis for over 85 years. Dithranol was applied to the skin in a paste for 8-24 hours. In order to improve the effectiveness 
this treatment was combined with a coal tar bath and exposure to ultraviolet light ${ }^{15}$. Such a therapeutic scheme is time consuming, difficult to accept by the patient from cosmetical point of view and can not be used out of the hospital. Therefore this therapeutic scheme has been more or less abandoned. Monotherapy with dithranol $0.3-3 \%$ applied to the skin for only 10-45 min. is just as effective. ${ }^{16,17}$ This treatment makes sense since dithranol is effective on cellular level in very low concentrations ${ }^{18}$ and penetrates faster in the parakeratotic stratum corneum of the psoriasis plaque than in the orthokeratotic stratum corneum of the surrounding skin. ${ }^{19}$ After 10-45 min. a detectable amount of dithranol has penetrated and the cream may be washed off. ${ }^{19}$ This procedure may diminish side-effects on the surrounding normal skin. However, for convenience of the patients dithranol cremes and sticks which are not washed off after application are still in use (Psoricream ${ }^{(\mathbb{R})}$ and Psoristick ${ }^{(R)}$ ).

Despite accurate application on the psoriasis plaques and short-term application, a brown discoloration of surrouding skin and skin-irritation with erythema are still common. ${ }^{20}$ There are no therapeutic measures available which may prevent these side-effects. Corticosteroids, coal tar or anti-histaminic drugs are unable to prevent or diminish skin irritation and erythema. ${ }^{21,2 n}$

\section{TOPICAL CORTICOSTEROIDS}

The topical corticosteroids are divided in four classes of potency (See table 1). The creams with topical steroids are colourless and do not smell and are therefore very well accepted by the patients. Further, these creams are simple to use and are therefore

\begin{tabular}{|c|c|}
\hline Table 1 & Classes of corticosteroidpotency \\
\hline Class I & $\begin{array}{l}\text { The least potent corticosteroids. They may be used in all skin areas and may be used for } \\
\text { maintenance therapies. They aro suitable for treatment of pruritis and moderate eczema. }\end{array}$ \\
\hline Class II & $\begin{array}{l}\text { More potent than corticosteroids from class I. } \\
\text { Suitable for eczemas, who do not respond to corticosteroids from class I. }\end{array}$ \\
\hline Class III & $\begin{array}{l}\text { Potent corticosteroids. They are indicated when corticosteroids from class II are not } \\
\text { offective. They are e.g. used in psoriasis, lichen simplex chronicus, lichen sclerosus et } \\
\text { atrophicus, discoide lupus erythematosus. Because of a risk of sideeffects these cortico- } \\
\text { steroids are not suitable for use in all skin areas and intermittent therapy is advisable. } \\
\text { Their use in children should be avoided. }\end{array}$ \\
\hline Class IV & $\begin{array}{l}\text { Most potent corticosteroïds. They are only suitable for short term therapies in adults } \\
\text { with therapy resistent dermatosis and with an insufficient reaction on corticosteroids of } \\
\text { class III. }\end{array}$ \\
\hline
\end{tabular}


frequently prescribed. However, the side-effects have to be considered. Potent corticosteroids on the face may cause a rosacea-like dermatitis. ${ }^{23}$ In the intertriginous areas striae distensae may be induced. ${ }^{24}$ Penetration of corticosteroids through the skin may, after long-term use on large skin areas, induce adrenal suppression. ${ }^{25}$ Therefore, large skin areas should only be treated for short periods. In long-term treatment with potent steroids there is a risk of skin atrophy sometimes with telangiectasia or senile purpura ${ }^{26}$ in all skin areas. After frequent use of topical steroids the beneficial effect may fade ${ }^{27}$ (tachyphylaxis). Intermittent application is just as effective as continuous application and may prevent tachyphylaxis. ${ }^{28}$

The combination therapy topical steroids with UV radiation is as effective as UV radiation alone. ${ }^{29}$ The use of topical steroids during therapy with retinoids has no advantages compared to retinoids alone. ${ }^{30}$

Treatment with dithranol may be as effective as treatment with topical corticosteroids of class III. ${ }^{31}$ Dithranol is therefore a good and safe alternative to the use of topical steroids.

\section{VITAMIN D3 DERIVATIVES}

Topical D3 derivatives have a beneficial effect on psoriasis. ${ }^{32}$ The effect on psoriasis is comparable to the effect of class III topical steroids. Metabolites of vitamin D3 with a good effect on psoriasis and hardly any effect on the calcium metabolism have been developed. ${ }^{33}$ This opens possibilities for a safe oral treatment. Vitamin D3 is still experimental and is not available for regular practice.

\section{ULTRAVIOLET RADIATION \\ UVB}

Sunlight has a beneficial effect on psoriasis. This effect is induced by ultraviolet light in the range between 280 and $315 \mathrm{~nm} \cdot{ }^{34,35}$ Ultraviolet $A$ (UVA) is, therefore, far less effective than UVB. Treatment with UVB is, when UVB doses are as high as the minimal erythema doses, as effective as treatment with psoralens in combination with UVA (PUVA). ${ }^{35}$ The remission period after UVB therapy is the same as the remission period after PUVA. ${ }^{35}$

UVB has advantages over PUVA: treatment is less time-consuming, lower heat load in the cabin, no risk of phototoxic reactions during sun exposure, sunglasses are not necessary and UVB might be less carcinogenic than PUVA. ${ }^{36}$ UVB has no side-effects beside a risk of skin bum and perhaps an increased risk for skin malignancies. 
Oral retinoids have an additive effect in UVB therapy just as they have in PUVA therapy. The combination therapy oral retinoids-UVB (ReUVB) is therefore more effective than UVB alone. ${ }^{37,38}$

As regards light therapy in case of psoriasis UVB is the first choice. In case of an inadequate effect the therapy may be changed to PUVA. The common UVB lamps produce a broad spectrum ultraviolet light in a range between $280-350 \mathrm{~nm}$, with a peak at $305 \mathrm{~nm}$. Recently a new UVB lamp has been developed (Philips TL-01), which produces a small spectrum $311-312 \mathrm{~nm}$ ultraviolet light. This lamp is probably more effective and less carcinogenic than commcn UVB lamps with a broad spectrum. ${ }^{39}$

\section{PUVA}

By oral use of psoralens the photosensitivity of the skin can be increased. Several psoralens are suitable for use in psoriasis. Because of the good effectiveness and high concentration in the skin 8-methoxypsoralen (8-MOP) is usually used. The spectrum of action for PUVA is between $320-335 \mathrm{~nm} .{ }^{40}$ The shorter wavelengths in the UVA range are more effective than the longer wavelengths. ${ }^{41}$

Before treatment the patients skin-type is assessed. This may be used to determine the patients initial dose UVA. However, assessment of the minimal phototoxic dose (MPD) is a more effective and accurate way to determine the initial dose. ${ }^{42}$ The possibilities in light schemes are not discussed.

An increased risk of skin malignancies, pregnancy, lactation, allergic reactions to psoralens, severe kidney- and liverfunction impairment, eye problems like cataract and other lens problems are contra-indictions for PUVA therapy. In case of photosensitive dermatoses like lupus erythematosus, porphyria cutanea tarda a.o. PUVA therapy for psoriasis is also contra-indicated.

Side-effects of PUVA on short term may be skin burns, bullae or pruritus. After use of psoralens, nausea and or headache may occur. Psoralens may deteriorate liver functions ${ }^{43}$ Development of bullous pemphigoid during PUVA therapy has been observed.

In the long run there is an increased risk of cataract. ${ }^{44}$ Therefore it is necessary that for 24 hours after use of psoralens sunglases are used to protect the eyes from ultraviolet. ${ }^{45}$ In large prospective studies no increased risk of cataract was detected when sunglasses were used..$^{46}$ Control of vision by an ophthalmologist before initiating PUVA therapy and every six months thereafter is advised. Further, the risk of skin cancers, especially squamous cell carinomas, is increased. ${ }^{47}$ However, an increased risk of skin cancer was not detected in every study ${ }^{48}$ and probably PUVA therapy does not affect the risk of melanoma. ${ }^{49}$ 
The combination therapies dithranol-PUVA, ${ }^{50}$ UVB-PUVA ${ }^{\text {s1 }}$ and methotrexate-PUVA ${ }^{52}$ are more effective than PUVA alone, but are hardly used. The combination with dithranol is time-consuming and may cause stains on clothes and bath. The combination with UVB does not have a higher risk of side-effects, ${ }^{51}$ but is technically more difficult to use and is perhaps not used for that reason. The combination with methotrexate has an unacceptable risk of development of skin cancers 33 and should not be used. Cyclosporine has no additive effect in PUVA therapy. ${ }^{54}$ This combination should not be used because of its risk of development of skin cancers. ." $^{\text {s. }}$

The combination therapy retinoids-PUVA (Re-PUVA) is safe and effective. With a lower cumulative dose of UVA in combination with a lower dose retinoids than should be necessary for monotherapy, a better result can be achieved. ${ }^{56}$ This combination is therefore used regularly.

Retinoids and PUVA do not potentiate each others side-effects. Retinoids probably inhibit skin malignancies. The use of retinoids in PUVA therapy may limit the carcinogenic effect of PUVA. ${ }^{56}$

\section{RETINOIDS}

Retinoids are derivatives of vitamin A (retinol). They have been in use for treatment of psoriasis for over ten years. For psoriasis etretinate was used at first but later on this was replaced by acitretin. Acitretin is the active metabolite of etretinate. The effectiveness and side-effects of acitretin are not different from etretinate. ${ }^{57}$ The initial dose is $0,5-1$ $\mathrm{mg} / \mathrm{kg} /$ day divided into two administrations. As soon as the psoriasis clears sufficiently, the dose will be tapered off to the minimal effective dose, which will be the maintained dose for the rest of the treatment period (6-9 months). In case the psoriasis relapses the doses may be increased temporarily.

This treatment is only effective in $60-70 \%$ of patients with psoriasis vulgaris, but better results are achieved in psoriasis with a tendency to erythrodermia ${ }^{58}$ and pustular types of psoriasis. ${ }^{59-61}$ An advantage is that during therapy symptoms of psoriatic arthritis decrease or disappear. ${ }^{62}$

Patients always observe side-effects during therapy. Mucous membranes will become drier, which my cause cheilitis, epistaxis or conjunctivitis. Due to an increased scaling of the skin on palms and soles the skin may become so thin that hand-work and walking become painful. Some patients have an itchy feeling or develop a sticky skin which may be accompanied by chills. More then $75 \%$ of the patients observe hairloss. The alopecia is reversible after discontinuation of the therapy. In rare cases retinoids may cause 
changes in the form of the hairshafts, erythrodermia, rosacea, photosensitivity or intracranial hypertension.

It is recommended not to use any retinoids in patients with an abnormal liver function. During therapy a rise in ASAT, ALAT and LDH can be observed regularly, even in patients with a normal liver function. The rise in ASAT, ALAT and LDH usually settles by itself despite continuation of the therapy with retinoids. ${ }^{61}$ There seems to be no morphological or functional effect on the liver. ${ }^{63,04}$ In rare cases however an acute toxic hepatitis may develop, in which case immediate withdrawal of the retinoid used is necessary. ${ }^{63}$

During maintenance therapy more then half of the patients develop hyperlipidemia, now and then associated with increased levels of cholesterol. ${ }^{\text {ob }}$ After dose-reduction or discontinuation of the therapy the serumlevels of the lipids return spontaneously to baseline value. High leveis of triglycerides are assocated with an increased risk of cardiovascular diseases. Therefore, an in crease in serum triglycerides should be prevented. This is possible with an appropriate diet, the use of at least three gram fish oil a day ${ }^{67}$ or in time withdrawal of the drig.

Further, hyperostosis of joints and spine may develop together with calcifications in tenoons and ngaments. ${ }^{.0,}$ it has been advised to take X-rays of cervical- and thoracic spine and of the calcaneus before starting long-term treatment with retinoids. During therapy $\mathrm{X}$-rays should be taken when problems emerge. These $\mathrm{X}$-rays can be compared with the X-rays taken before therapy started, which may help to find moderate changes. It does not seem necessary to take $\mathrm{X}$-rays regularly. In case one feels that a regular checkup is necessary, X-rays of the lateral aspect of the calcaneous will suffice.

After years of continuous therapy an increased muscle-tone has been observed, which may cause stiffness. ${ }^{70}$ Probably this phenomenon is caused by muscle-damage. ${ }^{71}$

Retinoids are teratogenic and remain in the body for a long time after discontinuation of the therapy. Therefore it is necessary that during therapy and during the period after treatment as advised by the company a reliable contraceptive is used. Retinoids may be used in children, but it must be considered that the retinoids may cause a premature closure of epiphysis. ${ }^{n}$ This may affect the length of the child in the long run.

New retinoids are being studied. Up till now those new retinoids show no advantage in effectiveness or side-effects compared to the retinoids which are in use already. 


\section{METHOTREXATE}

In the case of severe psoriasis resistant to topical therapy and ultraviolet radiation, methotrexate (MTX) may be used. Before therapy contraindications (see table 2) must be excluded. MTX is mainly excreted by the kidneys. Therefore, in case of renal impairment adjustment of the MTX dose is necessary. Concomitant medication with drugs that may interfere with MTX clearance increases the risk of side-effects. Drugs that interfere with the renal clearance of MTX are non-steroid anti-inflammatory drugs e.g. probe-

Table 2

(Relative) contraindications far treatment with methotrexate

Pregnuncy and lactation

Renal impairment

Impaired liver function

Active or recent hepatitis

Liver cirrhosis

Anemia, leukopenia or thrombopenia

Alcohol abusus

Active infections

Immunodeficiency

nicid and salicylates. Drugs that raise the level of free MTX in serum are e.g. salicylates, sulfonamides, tetracyline, and phenytoin. The risk of bone-marrow depression increases when folinic acid inhibitors like e.g. trimethoprim and sulfonamides are used at the same time. The side-effects may be prevented with an intermittent use of MTX. ${ }^{3}$ It is advisable to use MTX in a minimal effective dose. For psoriasis MTX is usually used in a dose of 7.5-30 mg once a week. MTX can be used intramuscularly or intravenously but this is uncommon. Often the MTX dose is divided in three administrations within a 36 hour period. This treatment scheme was developed to achieve maximal inhibition of the 37 hour cell-cyclus of the keratinocytes in psoriasis. ${ }^{74}$ It was supposed that the effectiveness of MTX in psoriasis was due to an anti-proliferative effect on keratinocytes. However, it is also possible that the effect of MTX is achieved by an immunomodulatory effect. ${ }^{75}$ In case this is true, there is no advantage in dividing the weekly dose into three administrations within 36 hours. There seems to be no difference in effectiveness between one and three administrations ${ }^{76}$ which may support the hypothesis of an immunomodulatory effect of MTX.

The side-effects of MTX are listed in table 3. The side-effects are, in case of a proper patient-selection, rare. However, development of serious side-effects can not be excluded, which makes regular control necessary. Especially the hepatotoxic effect of MTX with a risk of liver cirrhosis is important. ${ }^{n}$ The risk-factors for a hepatotoxic effect are listed in table 4. There is a large difference in the risk of irreversible liver damage found in several studies. ${ }^{78,79}$ Therefore, the exact risk is unknown. In all studies with a cumulative dose of MTX below 1,5 gram the incidence of liver cirrhosis is low. Further, the cirrhosis is in those cases usually mild and stabilizes despite continuation of therapy ${ }^{78,80}$. Improvement of the cirrhosis after discontinuation of therapy has been reported. ${ }^{81}$ 
Development of cirrhosis or fibrosis can not be detected by liver function tests. ${ }^{82}$ During MTX therapy a rise in ASAT and ALAT can often be seen. This has no clinical importance. Liver fibrosis can be detected by ultrasound. It is not known whether liver fibrosis can be detected in an early stage. This method, therefore, is not suitable for exclusion of developing liver fibrosis during MTX therapy. A liver biopsy is the only reliable way to detect livercirrhosis in an early stage. In the available literature it is advised to obtain a liver biopsy after a cumulative dose of 1,5 gram. ${ }^{76}$ The liver punction is repeated after every subsequence cumulative dose of 1,5 gram or earlier when the results of the liver histology makes it necessary. In some countries liver biopsies are also obtained before the initiation of MTX therapy. ${ }^{76,81}$ This histology may be a reference for following biopsies. Conceming the lowincidence of liver-cirrhosis and the morbidity of liverbiopsies a lower frequency of liverbiopsies may be justified. ${ }^{{ }^{3} 3}$

MTX induces reversible changes in spermatogenesis. It may be possible that when men father children during MTX therapy this may affect the fetus. ${ }^{84}$ Therefore, men
Table 3

Side-effocts wich may emerge during

methotrexate therapy for psoriasis

General:

Head ache, fever and tiredness

Skin:

Pruritis, urticaria, moderate reversibel alopecia, ecchymosis, acute ulceration of psoriasis lesions.

Blood:

Leukopenia, nnemia, thrombocytopenia

Gastrointestinali

Ulcerative stomatitis, nausen, anorexia and less frequently impairment of liver function, pharyngitis, enteritis, vomiting and diarrhoe

Urogenital:

Microscopic heematuria, cystitis, reversibel oligospermia, menorrhagia, nephropathy and changes in spermatogenesis and oogenesis.

Central nervous systemi

Headache, vertigo, dizziness, visual impairment and depressions

Table 4.

Risk factors for hepatotoxic side-effects during methotrexate therapy.

Alcohol abusus

Liver impairment in the patients history

Drug addiction

Diabetes mellitus

Obesitas

Concomitant use of hepatotoxic medication should not father children when they are on MTX therapy or in the period up to three months after MTX was withdrawn. MTX is teratogenic and when used in the first three months of pregnancy it frequently causes an abortion. ${ }^{\text {ss }}$ It is, therefore, necessary that women of childbearing age use a reliable contraceptive while on MTX therapy. After withdrawal of MTX there is no increased risk of abortion or fetal abnormalities. ${ }^{86}$ 
Low-dose MTX rarely has a toxic effect on the lungs. In patients with high temperature, dyspnoe and a non-productive cough not only an infectious cause should be considered but also a toxic effect of MTX. MTX may cause diffuse alveolar damage ${ }^{87}$ or interstitial pneumonitis with formation of granulomas and bronchiolitis. ${ }^{88}$ Immediate withdrawal of MTX and treatment with high-dose corticosteroids can improve this serious side-effect. ${ }^{88}$ The combination therapy retinoids-MTX is effective in psoriasis but increases the risk of a hepatotoxic effect ${ }^{89}$

It has been reported that topical MTX in a cream that enhances the penetration of MTX may be effective in psoriasis. ${ }^{90}$ Further studies are necessary to confirm this report.

\section{CYCLOSPORINE A}

Cyclosporine A (CsA) is highly effective in psoriasis. ${ }^{91,92}$ The use of CsA is hampered by side-effects. ${ }^{93}$ The side-effects are listed in table 5. CsA is contraindicated in patients with

\section{Table 5}

Side effects during low-dose cyclosporine therapy in psoriasis. The most frequent side effects are listed first.

Renal impairment

Hypertension

Infections (bacterial and viral)

Hypertrichosis

Tremor

Rise in ASAT, ALAT and gammaGT

Gingiva hyperplasia

Nausen

Paraesthesias

Hyperuricaemia

Acne

Convulsions

Rise in serum potassium

Muscle and/or joint pains

Leukopenia

Tiredness and weakness

Depression

Increased risk for squamous cell carcinomas of the skin. infections, deficient immune system, renal impairment, an increased risk of malignant disease or a history with malignant diseases. There is an increased risk of skin malignancies when the patient has ever used arsenic or has a high cumulative dose UV radiation (which is the case when a patient has had multiple PUVA treatments). In these patients CsA may induce rapid development of skin malignancies, mainly squamous cell carcinomas. ${ }^{55}$ In the case of concomitant medication which may raise the $\mathrm{Cs} A$ blood level (e.g. erythromycine, ketoconazol) or medication with a potential nefrotoxic action (e.g. non-steroid antinflammatory drugs and aminoglycosides) the risk of CsA induced side-effects is increased. The initial dose of CsA is $3-4 \mathrm{mg} / \mathrm{kg} /$ day divided into two administrations. If there is an insufficient response the CsA dose may be increased to $5 \mathrm{mg} / \mathrm{kg} /$ day. Because of an increasing risk of side-effects higher doses should be avoi- 
ded. As soon as there is sufficient improvement in the psoriasis, the CsA dose should be tapered off to the minimal effective dose. In case of side-effects the dose should be lowered by $25 \%$ each $2-4$ weeks until the side-effects have disappeared.

An increase in serum creatinin of $30 \%$ or more is associated with an increasing risk of irreversible renal damage. In case of a rise in blood-pressure the CsA dose can be decreased or treatment with anti-hypertensive drugs may be started. However, the use of diuretics or beta-blocking drugs should be avoided.

Before initiating treatment with CsA a full physical examination should be carried out. Possible risks of malignancies should be excluded and therefore in women older then $\mathbf{4 0}$ years a cervical smear should be obtained. Patients with an increased risk of renal impairment should be excluded.

A creatinine clearance and serum creatinine should be obtained twice on different days before initiating the first treatment with CsA. The mean serum creatinine and creatinine clearance are the baseline for measurements of effects of CsA during therapy. During therapy serum creatinine and potassium levels are obtained every fortnight until week 12 . Thereafter they are obtained monthly. The creatinine clearance is checked every three months. After 6 months it is checked once in a 6 month period. Blood pressure, liver functions, bilirubin, leukocytes with differentiation and protein in urine were checked monthly.

\section{FUMARIC ACID}

Oral therapy with monoethylfumaric acid and/or dimethylfumaric acid is effective in psoriasis. ${ }^{94.95}$ Dimethylfumaric acid is more effective than monoethylfumaric acid. ${ }^{94}$ Topical use of fumaric acid esters has no effect. This therapy is not used by many dermatologists because of the nefrotoxic and hepatotoxic side-effects ${ }^{95,96}$ and contradictionary reports about its effectiveness. Common side-effects are nausea, gastric upset, diarrhoea, malaise and redness associated with paraesthesia in the face and leukopenia.9 Renal and liver impairment are observed regularly. ${ }^{94,95}$ Acute renal failure due to necrosis of tubuli is possible. ${ }^{95.97}$ Therefore, regular control for side-effects is necessary. It is advisable to start with a low dose and to increase the dose weekly according to clinical effect and side-effects. In the case of a sufficient response the therapy is continued with the minimal effective dose. 


\section{CONCLUSION}

Psoriasis can be treated in various ways. Mild and moderate psoriasis can be treated with various topical therapies while psoriasis of the guttata type and more severe psoriasis can be treated with ultraviolet radiation in various regimens or with oral therapy. In oral therapy the retinoids are more effective for the pustular types of psoriasis than the other available drugs, but methotrexate and cyclosporine are in no doubt the most potent drugs for plaque type psoriasis.

It is clear that the choice of the optimal therapy depends on the type of psoriasis, the area involved and the severity of the disease. Further, the choice of a therapy depends on the (relative) contraindications for each therapy which may exist in the individual patient. Therefore, it is only possible to give optimal treatment in psoriasis when there is extensive knowledge about the responsiveness of the different types of psoriasis and sufficient experience with all therapies.

The activity and severity of psoriasis can change dramatically in time and also the relative contraindication for the patient may change. Accordingly the optimal therapy varies in time. Further, an increasing risk for side-effects usually limits the use of the prescribed therapy and makes a regular shift of therapy necessary.

Because experience is so important in the treatment of psoriasis, most patients want and have to be treated by a dermatologist. Treatment by a doctor who is only able to prescribe one or two therapies (e.g. methotrexate and cyclosporine) is usually insufficient and is potentially hazardous. 


\section{EFFECTS OF CYCLOSPORINE ON IMMUNOLOGIC MECHANISMS IN PSORIASIS}

The concept that circulating leukocytes might provide stimulatory signals that are critical for the development or maintenance of psoriatic lesions has been considered for some time. ${ }^{97}$ In association with increased numbers of $T$ cells (both activated and unactivated), increased numbers and types of antigen-presenting cells (APCs) were found in the epidermis and dermis of psoriatic lesions. ${ }^{99,100}$ The activated $T$ cells appeared to be producing lymphokines, ${ }^{101}$ as evidenced by the expression of lymphokine-induced membrane molecules on lesional keratinocytes. ${ }^{99,102-104}$ APCs found in psoriatic lesions are highly stimulatory for $\mathrm{T}$ cells, ${ }^{99}$ and lymphokines released from the $\mathrm{T}$ cells of psoriatic lesions cause keratinocyte hyperproliferation and cause abnormal keratinocyte expression of markers also expressed in psoriatic keratinocytes. ${ }^{105}$ These data support the concept that cellular immunologic processes are active in psoriasis in a manner that further promotes pathophysiologic mechanisms. The efficacy of cyclosporine $\mathrm{A}(\mathrm{CsA})$ in the treatment of psoriasis gave credence to the hypothesis that mechanisms such as those described might be important in maintaining a psoriatic lesion.

\section{CYCLOSPORINE EFFECTS}

Although CsA might act on several types of cells that are involved in psoriasis, on the basis of data from both in vitro and in vivo studies, it probably exerts especially potent effects on $\mathrm{T}$ cells. In vitro studies show that CsA blocks the increase in lymphokine messenger RNA, which occurs after triggering of the T-cell receptor for antigens ${ }^{106}$ although the drug's action is distal to inositol 1,4,5-triphosphate $\left(\mathrm{IP}_{3}\right)$ generation, calcium mobilization, and interleukin 2 (IL-2) receptor gene induction. ${ }^{107}$

It has been postulated that CsA's differential effect on the triggering of T-cell genes is related to lymphokine gene promoter dependence on binding by nuclear factors that require refolding, whereas CsA-resistant genes (e.g. the IL-2 receptor gene promoter) can be activated by nuclear proteins that do not require refolding. ${ }^{108}$ The major intra-cellular receptor for CsA is cyclophilin. ${ }^{109}$ Because cyclophilin is a peptidyl-propyl cis-trans isomerase (rotamase) ${ }^{110}$ it appears that CsA can block the peptide bond rotation that is required for the proper folding of proteins induced by activation of T-cell receptors. Folding may be necessary in order for nuclear proteins to bind to lymphokine gene promoter regions. Its inhibition would be a critical interruption in the amplification of immune responses. ${ }^{108}$ 
CsA's mechanisms of action in vivo are identical to those seen in vitro. However, because the drug blocks many, but not all, of the postreceptor triggering events in $\mathrm{T}$ cells, certain aspects of T-cell priming, proliferation, and differentiation can occur in vivo after antigen stimulation. ${ }^{106}$ Thus, during in vivo therapy with CsA, T cells were primed and activated and differentiated from precytotoxic $T$ lymphocytes (pre-CTL) to CTL, but were blocked from activating the lymphokine genes needed for proliferation, for amplification of immune responses, and for development of CTL effector activity. The blocking of lymphokines includes IL-2, interferon-gamma, IL-4, and granulocyte-macrophage/colonystimulating factor (GM-CSF). ${ }^{11,112}$

Examples of CsA-resistant T-cell activation include CD8 $8^{+} \mathrm{CTL}$ clones, ${ }^{113}$ and activation by the CD28 pathway. ${ }^{114}$ CsA's ability to block $\mathrm{T}$ cells at the level of lymphokine production while leaving antigen-reactive cells poised to continue activation when the drug is withdrawn ${ }^{106}$ is consistent with the findings that lymphokine-induced proteins on keratinocyte membranes disappear before $T$ cells and macrophages disappear ${ }^{11}$ and that remissions after withdrawal of therapy in psoriasis patients are relatively brief.

Despite its potent effects on lymphokine gene expression in vivo, ${ }^{116} \mathrm{CsA}$ may exert direct effects on a variety of other cells that potentially are involved in the pathogenesis of psoriasis. These include keratinocytes, ${ }^{117}$ endothelial cells, ${ }^{118}$ neutrophils ${ }^{119}$ and mast cells. ${ }^{120}$ Furthermore, although induction of monocyte IL-1, tumor necrosis factor (TNF), c myc, HLA-DR, and gamma-IP-10 is not affected by CsA, ${ }^{112}$ the antigen-presenting activity of Langerhans cells and other APCs does appear to be sensitive to the drug. ${ }^{115}$ When CsA is used to treat psoriasis, lymphokine-dependent events are blocked, although direct keratinocyte antiproliferative events are not likely to occur at achievable in vivo concentrations. The level of residual psoriasis appears to be closely linked to the presence of a macrophage whose antigen-presenting activity appears to be resistant to CsA. Additional effects are likely, but more direct data are needed to determine CsA's effect on mast cells, neutrophils, or endothelial cells in psoriasis patients.

\section{CYCLOSPORINE EFFECTS IN PSORLASIS}

T cells

Early histologic changes that occur during development of psoriasis lesions involve alterations in blood vessels and the appearance of mononuclear cells, primarily $T$ lymphocytes and macrophage-related cells. ${ }^{100,115}$ Although the lesions contain CD8+ (suppressor or cytotoxic) $\mathrm{T}$ lymphocytes ${ }^{100}$ the $\mathrm{T}$ cells are composed predominantly of $\mathrm{CD}^{+}$helper or recall antigen-reactive memory $\mathrm{T}$ cells. ${ }^{100,121,122}$ In psoriatic skin, a large 
proportion of these $\mathrm{CD}^{*}$ cells may be recruited in a non-antigen-specific manner via specialized molecules on endothelial cells in psoriatic skin. ${ }^{103}$ Even so, a subset appears to undergo specific activation within the lesions. Lesional T-cell HLA-DR expression, ${ }^{100}$ IL-2 receptor expression ${ }^{104}$ and entry into cell cycle or proliferation ${ }^{122}$ indicate that a subset of $\mathrm{T}$ cells may be able to recognize antigen bound within class II major histocompatibility complex (MHC)(HLA-DR) molecules on APCs in psoriatic skin. ${ }^{12}$

CsA treatment of psoriasis patients causes a reduction in the density of all T-cell subsets in both the dermis and epidermis of lesions. ${ }^{100,123}$ Decreased numbers of cells staining with the antibody to the IL-2 receptor seem to indicate that the drug has a selective effect on the IL-2 receptor positive, $\mathrm{CD} 3^{+} \mathrm{T}$ cells during treatment. ${ }^{123}$

Activated T-cell production of lymphokines such as interferon-gamma, ${ }^{101}$ in psoriatic lesions is the presumed mechanism by which keratinocytes abnormally express the molecules HLA-DR, ICAM-1, gamma-IP-10, OKM5, and CDw60.99,103-105,124 The expression of these markers can be interpreted as an in vivo bioassay of lymphokine release in the lesional milieu. An early and dramatic effect of Csa treatment of psoriasis is the rapid disappearance of interferon-gamma-inducible proteins on the surface of psoriatic keratinocytes. ${ }^{115}$

Multiple populations of $T$ cells are present in lesional psoriatic skin and these have various patterns of lymphokine production. ${ }^{105}$ Consequently, other lymphokines besides interferon-gamma may be reduced by CsA. Because preliminary results indicate that $\mathrm{T}$ cell lymphokines can induce keratinocyte proliferation directly ${ }^{125}$ a driving force for keratinocyte proliferation would be removed during CsA therapy.

\section{Antigen-presenting cells}

Both Langerhans cells and non-Langerhans APCs are present in the dermis and epidermis of patients with psoriasis. Moreover, Langerhans cell distribution and morphology are somewhat altered in psoriatic epidermis. ${ }^{100,126}$ Whereas $\mathrm{CDI}^{+} \mathrm{DR}^{+}$Langerhans cells are the primary immunologic cell type in normal human epidermis, ${ }^{127}$ a population of CDI$\mathrm{DR}^{+}$leukocytes are found in psoriatic epidermis. Some of these appear to be macrophages and some seem to represent $\mathrm{CD}^{-}$cells expressing Birbeck granules. ${ }^{128}$

The abnormal CD1-DR ${ }^{+}$cell population is responsible for the increased APC activity in psoriatic epidermis." It is not yet known whether these cells are also responsible for the ability of epidermal cells from lesional psoriatic skin to activate autologous $T$ cells from blood ${ }^{129}$ or lesional skin. After CsA therapy, APC activity is altered in the skin. After 7 days of therapy, antigen-presenting activity was virtually eradicated in clinically unin- 
volved skin in which Langerhans cells were the primary APCs. ${ }^{115}$ But Langerhans cells in lesional epidermis contribute only minimally to the antigen presenting activity, ${ }^{99}$ and therefore their inactivation would cause little change in the APC activity of lesional epidermis. Consistent with this hypothesis is the fact that antigen-presenting activity of lesional epidermis was only partly reduced at 7 days. Numbers of the abnormal APC population (non-Langerhans cell $\mathrm{CDI}^{-} \mathrm{DR}^{+}$leukocytes) showed a similar partial decrease at 7 days and their loss progressed with further therapy. The numbers of these cells correlate with the level of APC activity. Their numbers also correlate closely with the improvement in severity scores. ${ }^{115}$ Thus there appears to be a population of non-Langerhans cell $\mathrm{CD}^{-} \mathrm{DR}^{+}$macrophages whose APC function, relative to Langerhans cells, is resistant to CsA. However, the progressive decline in their population during therapy indicates that their presence in the epidermis may depend on continued recruitment by $T$ cell lymphokines, which are inhibited by CsA therapy. Moreover, their close correlation with lesional severity scores indicates that their presence and activity are closely linked to mechanisms of lesion maintenance.

\section{Keratinocytes}

The question of whether CsA also has a direct effect on keratinocyte proliferation is controversial. ${ }^{117,123} \mathrm{CsA}$ may not have a major clinical antiproliferative effect on keratinocytes because the intracellular drug concentration needed to inhibit human keratinocyte proliferation may not be achievable in vivo during psoriasis therapy. During CsA treatment of psoriasis patients, no change was noted in keratinocyte epidermal growth factor receptor levels. ${ }^{123}$ 


\section{INDICATIONS FOR CYCLOSPORINE OTHER THEN PSORIASIS AND ATOPIC DERMATITIS.}

The efficacy of oral cyclosporine A (CsA) for the treatment of psoriasis and atopic dermatitis has been demonstrated in several studies. ${ }^{130-132}$ However, oral cyclosporine has been used in the treatment of several different dermatoses. This article reviews a profile of dermatoses (other then psoriasis or atopic dermatitis) in which CsA therapy has been used. These dermatoses can be categorized according to their responsiveness to CsA therapy. This classification, however, should be considered provisional inasmuch as the data on CsA treatment are derived mostly from single case reports or small series of cases that may be biased.

\section{DISEASES WITH EXCELLENT RESPONSIVENESS TO CYCLOSPORINE}

\section{Pyoderma Gangrenoswm}

There have been reported cases of patients with pyoderma gangrenosum, refractory to other therapy, who have been treated with CsA. Most of these patients demonstrated a marked response ${ }^{133.134}$ to CsA in doses of 6 to $10 \mathrm{mg} / \mathrm{kg} /$ day. A maintenance dose of CsA 3 to $4 \mathrm{mg} / \mathrm{kg} /$ day is often sufficient and even long-term remission without any therapy after the lesions had been healed with CsA has been reported. ${ }^{13}$ This indicate that CsA is useful in the treatment of patients with refractory pyoderma gangrenosum and suggest an immune mechanism in the pathogenesis of this disorder.

\section{Behçet's Disease}

The beneficial effect of systemic CsA, 5 to $10 \mathrm{mg} / \mathrm{kg} /$ day, on the ocular complications of Behçet's disease has been well documented. ${ }^{136,137}$ Coincidental improvement of mucocutaneous and musculoskeletal manifestations has been observed in several reports. ${ }^{138,139} \mathrm{CsA}$, 5 to $10 \mathrm{mg} / \mathrm{kg} /$ day, is superior in its ability to alleviate ocular disease compared with either corticosteroids or chlorambucil. However, corticosteroids and chlorambucil permitted better control of the extraocular manifestations, ${ }^{140}$ but CsA was found to be superior to colchicine in the treatment of both ocular and extraocular disease. ${ }^{141}$ Longterm maintenance therapy is required because the disease relapses when the drug is discontinued.

\section{Epidermolysis Bullosa Acquisira}

All reported cases of patients treated with oral CsA (6 to $9 \mathrm{mg} / \mathrm{kg} /$ day) improved within weeks of starting cyclosporine therapy. ${ }^{142,143} \mathrm{CsA}$ is also effective in cases of epider- 
molysis bullosa acquisita that have previously been refractory to other therapies, including corticosteroids, gold, dapsone, isotretinoin, azathioprine, cyclophosphamide, and methotrexate. In conjunction with corticosteroids, the addition of CsA makes a significant reduction in the dose of corticosteroids possible.

In Epidermolysis Bullosa Acquisita there may be T-cell dependent autoantobodies to type VII collagen in the basement membrane zone. ${ }^{143}$ CsA may inhibit the activation of immune cells resulting from autoantibody binding to tissue.

\section{Lichen Planus}

Complete clearing of severe cutaneous lichen planus after 8 weeks of therapy with oral CsA, $6 \mathrm{mg} / \mathrm{kg} /$ day, has been reported in several patients. ${ }^{14,145}$ After cessation of CsA, some patients relapse after 3 to 4 weeks but others remain in remission. ${ }^{145}$

Erosive oral lichen planus showed significant healing with topical CsA. ${ }^{146,147}$ No significant systemic absorption or side effect was reported.

\section{Pityriasis Lichenoides Chronica}

In one case report a good response to CsA has been observed. The response may be explained by an inhibitory effect on the activation of helper/inducer $T$ cells and subsequent production of inflammatory lymphokines.

\section{DISEASES WITH MODERATE RESPONSIVENESS TO CYCLOSPORINE}

\section{Alopecia}

Oral therapy with CsA in a dose above $6 \mathrm{mg} / \mathrm{kg} /$ day is effective in the treatment of severe alopecia areata. ${ }^{148}$ However, marked hair loss occurres within 3 months after discontinuation of CsA. Topical cyclosporine has been used with mixed results. In the most recent studies topical CsA seems not effective. ${ }^{149}$

In two patients with androgentic alopecia who received oral CsA, $7.5 \mathrm{mg} / \mathrm{kg} / \mathrm{day}$ ) for psoriasis, hair regrowth was observed. ${ }^{150}$ However, the side-effects of CsA maintenance therapy limits or prevents therapy with CSA for alopecia. The mechanism of action of CsA on hair growth is unknown.

\section{Chronic Photodermatoses}

Persistent light reaction and actinic reticuloid are characterized by severe photosensitivity and dermal lymphocytic infiltrates. In dosages of 2.5 to $6.0 \mathrm{mg} / \mathrm{kg} /$ day, CsA has been 
effecitive in inducing remissions in these conditions. ${ }^{151,152}$ On discontinuation of $\operatorname{CsA}$, the dermatoses promptly relapse.

Development of pseudolymphoma and malignant $\mathrm{T}$-cell lymphoma during csA therapy has been reported in a patient with actinic reticuloid. ${ }^{153}$ Since CsA may induce lymphoma's and may enhance growth of several malignancies the use of CsA in potentially premalignant conditons is potentially dangerous.

\section{Pemphigus Vulgaris}

$\mathrm{CsA}$ in a dose of at least $5 \mathrm{mg} / \mathrm{kg} /$ day is able to induce rapid improvement in Pemphigus Vulgaris. ${ }^{144-156} \mathrm{CsA}$ alone is usually unable to controll the disease sufficiently but the main advantage of using CsA is to allow a decrease in corticosteroid doses and to permit treating cortocosteroid-resistant pemphigus vulgaris. This effect is promptly lost once CsA therapy has been discontinued. Maintenace therapy of CsA in a dose of 3 to $6 \mathrm{mg} / \mathrm{kg} /$ day is required.

\section{Pemphigoid}

CsA is beneficial in the treatment of pemphigoid primarily as a steroid-sparing agent. ${ }^{156,157}$ Relapses of pemphigoid occur when therapy is discontinued.

\section{Acrodermatitis Continua of Hallopeau}

Few case reports are available in which a moderate improvement during CsA tharapy has been observed. However, a CsA dose above $8 \mathrm{mg} / \mathrm{kg} /$ day is necessary. After discontinuation of CsA the disease relapse so maintenance therapy is necessary. ${ }^{158}$ Side-effects of this maintenance dose can be expected.

\section{Granuloma Annulare}

In two patients there was moderate flattening of the lesions and decrease in erythema, although some papules still persisted after 8 weeks. No new lesions developed during therapy.

\section{DISEASES WITH VARIABLE RESPONSES TO CYCLOSPORINE}

\section{Lupus Erythematosus}

CsA has been used to treat steroid-dependent or steroid-resistant systemic lupus erythematosus. Used alone, CsA does not appear to have significant efficacy ${ }^{159}$ but CsA is able to 
allow a decrease in corticosteroid doses. CsA appears to be a more effective steroidsparing agent than azathioprine. ${ }^{160}$

However, CsA may be associated with deterioration of renal function, especially in patients with preexisting lupus nephritis. ${ }^{161}$ A possible case of CsA-induced severe relapse of systemic lupus erythematosus also has been reported. ${ }^{162}$

CsA has shown a mixed effect when used to treat cutaneous lupus erythematosus. Improvement in the skin lesions and the systemic manifestations was noted in three of four patients ${ }^{163}$ but in another report no benefit was found in one patient with severe discoid lupus erythematosus. ${ }^{104}$

\section{Dermatomyositis and Polymyositis}

As adjunctive therapy to cortocosteroids, CsA may be beneficial in patients with juvenile dermatomyositis refractory to corticosteroids and cytotoxic agents. ${ }^{165}$

The response of adult dermatomyositis and polymyositis to adjunctive CsA therapy is unpredictable. Both improvement ${ }^{166}$ and lack of improvement ${ }^{167}$ have been reported. For these conditions, the usual dosage is 5 to $10 \mathrm{mg} / \mathrm{kg} /$ day.

\section{Scleroderma}

CsA, 4 to $10 \mathrm{mg} / \mathrm{kg} /$ day, has been used to treat scleroderma. In some patients an improvement was observed ${ }^{168,169}$ while in others no signficant response was noted. Two patients with progressive systemic sclerosis in whom kidney failure developed within 2 months after treatment with CsA 2.5 to $5 \mathrm{mg} / \mathrm{kg} /$ day have been reported. ${ }^{170}$ This discourages the use of CsA in patients with scleroderma.

\section{Darier's disease}

One patient with a good response and one patient with a mild response on CsA therapy has been reported. The mechanism by which CsA might have an effect in Darier's disease is not clear. There may be some degree of immune dysregulation, with defective cellmediated immunity and abnormal lymphocyte responsiveness to $\mathrm{T}$ - and B-cell mitogens. ${ }^{171}$

\section{Hidradenitis Suppurativa}

One patient has shown a moderate response on CsA therapy. Paradoxically, the development of hidradenitis in two patients receiving CsA therapy for ocular inflammation disorders has been reported. ${ }^{172}$ The reason for these discordant observations is unclear. 


\section{Cutaneous Sarcoidosis}

Sarcoidosis is a cell-mediated response with granulomas gormed by macrophages/histiocytes interacting with $T$ cells, particularly helper $T$ cells and activated $T$ cells secreting lymphokines. ${ }^{173,174}$ CsA might be expected to be effective in these two conditions by inhibiting the activation of $\mathrm{T}$ cells and decreasing the subsequent lymphokine production and cellular responses. However, the results from case reports are inconsistent. There are reported cases of succesful therapy ${ }^{175}$ and cases in which the patients did not show improvement. More patients have to be treated before any statement about the efficacy of CsA in this condition can be made.

\section{Vitiligo}

Immunologic abnormalities have been reported in vitiligo. In the peripheral blood of these patients the man total number of $T$ lymphocytes and helper $T$ cells is significantly depressed and suppressor $\mathbf{T}$ cells and natural killer cells are elevated compared with controls. ${ }^{\text {No }}$ in addition, antimelanocyte antibodies may occur in vitiligo. ${ }^{\prime \prime \prime}$ However, it is unclear if melanocyte destruction is immunologically mediated and if so, whether destruction occurs as a result of B-cell-derived autoantibodies or because of cytolytic $\mathrm{T}$ cells. Vitiliginous skin shows a lack of inflammatory T-cell infiltrate producing lymphokines. Therefore CsA might be expected ineffective for this disease.

In two patients a mild to moderate response with perifollicular repigmentation was observed. A third patient showed no response. Studies designed to ascertain whether CsA can inhibit or delay the progression of vitiligo are needed.

\section{DISEASES WITH MINIMAL RESPONSE TO CYCLOSPORINE}

\section{Ichthyosis}

CsA in a dose of $6 \mathrm{mg} / \mathrm{kg} /$ day was ineffective in patients with lamellar ichthyosis. ${ }^{178}$ Some patients even show worsening of the disease.

\section{Pityriasis Rubra Pilaris}

In three patients a minimal improvement has been observed during CsA therapy while in another case report a patient did not respond. ${ }^{179,180}$ This suggests that Pityriasis Rubra Pilaris may not be T-cell mediated or mediated by a non-CsA-sensitive T-cell population. 


\section{Cutaneous T-cell Lymphoma}

Patients with mycosis fungoides or Sézary syndrome respond rapidly to CsA, 5 to 25 $\mathrm{mg} / \mathrm{kg} /$ day, with marked improvement of their cutaneous symptoms. ${ }^{181,182}$ However, clinical improvement is usually transient and patients soon experience rapid deterioration of their disease. ${ }^{183.184}$

As can be seen in this review, CsA is used in a rapidly increasing variety of skin disorders. In some inflammatory disorders a positive effect of CsA could be expected but in other skin disorders there were no indications whatsoever that CsA therapy could be effective. In the latter, sometimes unexpectedly CsA has some effect, but regularly no substantial effect was reported.

When new potent therapies become available, they are often used with to much enthousiasm; forgetting the (relative) contraindications, forgetting the side-effects, and use for unjustified indications. After incidents with side-effects and disappointing results in therapy for unjustified indications the enthousiastic use of the drug decreases and a rational use is established.

CsA may have important and irreversible side-effects. Therefore, experimenting with this drug on an individual bases can be hazardous. CsA should only be used in practise for well established indications and the use of CsA beyond the safety-guidelines can not be justified. 
1. Baker H. Pworiasis. In Textbook of Dermatology by Rook A et al. Blackwell Scientific Publ. Fourth edition 1988; pp 1469-1491.

2. Lover F, Schaumburg-Lever G. Histopathology of the skin. J.B.Lippincott comp. Philadelphia. Seventh edition 1990: pp 156-164.

3. Wuepper KD, Coulter SN, Haberman A. Psoriasis vulgaris: a genetic approach. J Invest Dermatol 1990; 95: 2S-4S.

4. Downey DJ, Finlay AY. Combined short-contact crude coal tar and dithranol therapy for psoriasis. Clin Exp Dermatol 1986; 11: 498-501.

5. Young $\mathrm{E}$, van Weelden $\mathrm{H}$. Treatment of psoriasis with a combination of dithranol and coal tar. $\mathrm{Br} \mathrm{J}$ Dermatol 1987; 116: 281-282.

6. Müller R, Naumann E, Detmar M, Orfanos CE. Stabilität von Cignolin (Dithranol) in teerhaltigen Salben mit und ohne Salicylsalurezusatz. Hautarzt 1987; 38: 107-111.

7. Lowe NJ, Wortzman MS, Breeding J, Koudsi H, et al. Coal tar phototherapy for psoriasis re-evaluated: erythemogenic versus suberythemogenic ultraviolet with a tar extract in oil and crude coal tar. J Am Acad Dermatol 1983; 8: 781-789.

8. Schoket B, Horkay I, Kósa A, Paldeak L et al. Formation of DNA adducts in the skin of sporiasis patients, in human skin in organ culture, and in mouse skin and lung following topical application of coal-tar and juniper tar. J Invest Derrnatol 1990; 94: 241-246.

9. Sarto F, Zordan M, Tomanin R, Mazzotti D et al. Chromosomal alterations in peripheral blood lymphocytes, urinary mutagenicity and excretion of polycyclic aromatic hydrocarbons in six psoriatic patients undergoing coal tar therapy. Carcinogenesis 1989; 10: 329-334.

10. Clonfero E, Zordan M, Cottica D, Venier P et al. Mutagenic activity and polycyclic aromatic hydrocarbon levels in urine of humans exposed to therapeutical coal tur.

Carcinogenesis 1986; 7:819-823.

11. Stem RS, Zierler S, Parrish JA. Skin carcinoma in patients with psoriasis treated with topical tar and ultraiolet radiation. Lancet 1980; i; 732-734.

12. Jones SK, MacKie RM, Hole DJ, Gillis CR. Further evidence of the safety of tar in the management of psoriasis. Br J Dermatol 1985; 113: 97-101.

13. Pittelkow MR, Perry HO, Muller SA, Maughan Z, et al. Skin carcinoma in patients with psoriasis treated with coal tar. A 25-year follow-up study. Arch Dermatol 1981; 117: 465-468.

14. Stern RS, Zierler S, Parrish JA. Skin carcinoma in patients with psoriasis treated with topical tar and artificial ultra violet radiation. Lancet 1980; i: 732-735.

15. Ingram JT. The approach to psoriasis. Br Med J 1953; 2: 591-594.

16. Lowe NJ, Ashton RE, Koudsi H, Verschoore M, et al. Anthralin for psoriasis: Short-contact anthralin therapy compared with topical steroid and conventional anthralin. J Am Acad Dermatol 1984; 10:69-72

17. Paramsothy $Y$, Collins $M$, Lawrence $C M$. Effect of UVB therapy and a coal tar bath on short contact dithranol treatment for psoriasis. Br J Dermatol 1988; 118: 783-789.

18. Reichert U, Jacques $Y$, Grangeret $M$, Schmidt $R$. Antirespiratory and antiproliferative activity of anthralin in cultured human keratinocytes. J Invest Dermatol 1985; 84: 130-134.

19. Schaefer H, Farber EM, Goldberg L, Schalla W. Limited application period for dithranol in psoriasis. Br J Dermatol 1980; 102: 571-573.

20. Paramsothy $\mathrm{Y}$, Lawrence $\mathrm{CM}$. Time course and intensity of anthralin inflammation on involved and uninvolved psoriate skin. Br J Dermatol 1987; 116: 517-519.

21. Kerkhof van de PCM, Timmerman MGH. The effect of clobetasol 17-propionate and crude coal tar on dithranol induced inflammation. Acta Derm Venereol (Stockh) 1990; 70: 434-437.

22. Misch K, Davies M, Greaves M, Coutts A. Pharmacological studies of anthralin erythema. Br J Dermatol 1981; 105 Suppl 20: 82-86.

23. Marghescu S, Wolff HH. Rosaçe et dermatite périorale. Le point de vue allemand. J Agrégés 1977; 10: $455-459$.

24. Gschwandtner WR. Striae cutis atrophicae nach Lokalbehandlung mit Corticosteroiden. Hautarzt 1973; 24: 70-73. 
25. Keczkes K, Teasdale P, Wiseman RA, Mugglestone CJ. Plasma cortisol values after topical applieation of diflucortolone valerate $(0.3 \%)$ or clobetasol propionate $(0.05 \%)$ in psoriatic patients. $\mathrm{Br} \mathrm{J}$ Dermatol 1978; 99: 417-420.

26. Stevanovic DV. Corticosteroid-induced atrophy of the skin with telangiectasia. A clinical and experimental study. Br J Dermatol 1972; 87: 548-566.

27. Singh G, Singh PK. Tachyphylaxis to topical steroid measured by histamine-induced wheal suppression. Int J Dermatol 1986; 25: 324-326

28. Harst van de LCA, de Jonge H, Pot F, Polano MK. Comparison of two application schedules for clobetasol 17 propionate. Acta Derm Venereol (Stockh) 1982; 62: 270-273.

29. Petrozzi JW. Topical steroids and UV radiation in psoriasis. Arch Dermatol 1983: 119: 207-210.

30. Rhee HJ van der, Polano MK. treatment of psoriasis vulgaris with a low-dosage Ro 10-9359 (Tigason) orally combined with corticosteroids topically. In: Orfanos CE et al. Retinoids. Advances in basic research and therapy. Springer, Berlin Heidelberg New York, pp 193-199.

31. Marriott PJ, Munro DD. Clobetasol propionate ointment compared with dithranol in Lassar's paste in the treatment of psoriasis. Br J Dermatol 1976; 94, Suppl 12: 101-106.

32. Kragballe K, Gjertsen BT, de Hoop D, Karlsmark $\mathrm{T}$ et al. Double-blind, right/left comparison of calcipotriol and bethamethasone valerate in treatment of psoriasis vulgaris.

The Lancet 1991; 337: 193-196

33. Morimoto S, Imanaka S, Koh E, Shiraishi $T$, et al. Comparison of the inhibitions of proliferation of normal and psoriatic fibroblasts by 1a,25-dihydroxyvitamin $D_{3}$ and synthetic analogues of vitamin $D_{3}$ with an oxygen atom in their side chain. Biochem Interm 1989; 19: 1143-1149.

34. Parrish JA, Jaenicke KF. Action spectrum for phototherapy of psoriasis. J Invest Dermatol 1981; 76: 359-362.

35. Van Weelden H, Young E, van der Leun JC. Therapy of psoriasis: comparison of photochemotherapy and several variants of phototherapy. Br J Dermatol 1980; 103: 1-9.

36. Slaper H, Schothorst AA, van der Leun JC. Risk evaluation of UVB therapy for psoriasis: comparison of calculated risk for UVB therapy and observed risk in PUVA-treated patients. Photodermatol 1986; 3 : 271-283.

37. Iest J, Boer J. Combined treatment of psoriasis with acitretin and UVB phototherapy compared with acitretin alone and UVB alone. Br J Dermatol 1989; 120: 665-670.

38. Ruzicka T, Sommerburg C, Braun-Falco O, Küster W, et al. Efficiency of acitretin in combination with UVB in treatment of severe psoriasis. Arch Dermatol 1990; 126: 482-486.

39. Van Weelden H, Baart de la Faille H, Young E, van der Leun JC. A new development in UVB phototherapy of psoriasis. Br J Dermatol 1988; 119: 11-19.

40. Fleming MG, Brody N. Biologic effectiveness of black light fluorescent lamps for PUVA. J Am Acad Dermatol 1985; 12: 894.

41. Morison WL, Pike RA. Spectral power distributions of radiation sources used in phototherapy and photochemotherapy. J Am Acad Dermatol 1984; 10: 64-68.

42. Wolff K, Gschnait F, Honigsmann H, Konrad K, et al. Phototesting and dosimetry for photochemotherapy. Br J Dermatol 1977; 96: 1-10.

43. Freeman K, Warin AP. Deterioration of liver function during PUVA therapy. Photodermatology 1984; 1: $147-148$.

44. Boukes RJ, Bruynzeel DP. Ocular findings in 340 long-term treated PUVA patients. Photodermatology $1985 ; 2 ; 178-180$.

45. Morison WL, Strickland PT. Environmental UVA radiation and eye protection during PUVA therapy. J Am Acad Dermatol 1983; 9: 522-525.

46. Stern RS, Parrish JA, Fitzpatrick TB. Ocular findings in patients treated with PUVA. J Invest Dermatol 1985; 85: 269-273.

47. Stern RS, Thibodeau LA, Kleinerman RA, Parrish JA, et al. Risk of cutaneous carcinoma in patients treated with oral methoxsalen photochemotherapy for psoriasis. N Eng J Med 1979; 300: 809-813.

48. Henseler T, Christophers E, Hönigsmann H, Wolff K, et al. Skin tumors in the European PUVA study. J Am Acad Dermatol 1987; 16: 108-116. 
49. Gupta AK, Stern RS, Swanson NA, Anderson TF, et al. Cuteneous melanomas in patients treated with psoralens plus ultraviolet A. J Am Acad Dermatol 1988; 19: 67-76.

50. Cripps DJ, Lowe NJ. Photochemotherapy for psoriasis remission times. Psoralens and UV-A and combined photochemotherapy with anthralin. Clin Exp Dermatol 1979; 4: 477-483.

51. Momtax TK, Parrish JA. Combination of psoralens and ultraviolet $A$ and ultraviolet $B$ in the treatment of psoriasis vulgaris: a bilateral comparison study. J Am Acad Dermatol 1984; 10: 481-486.

52. Morison WL, Momtez-TK, Parrish JA, Fitzpatrick TB. Combined methotrexate-PUVA therapy in the treatment of psoriasis. J Am Acad Dermatol 1982; 6: 46-51.

53. Morison WL. PUVA combination therapy. Photodermatology 1985; 2: 229-236.

54. Korstanje MJ. Combination-therapy cyclosporin A-PUVA in psoriasis. Act Derm Venereol (Stockh) 1990; 70: 89-90.

55. Korstanje MJ, van de Staak WJBM. High cumulative dose of ultraviolet rodiation is a contra-indication for cyclosporin therapy. Clin Exp Dermatol 1990; 5: 76.

56. Lauharanta J, Juvakoski T, Lessus A. A clinical evaluation of the effects of an aromatic retinoid (Tigason), combination of retinoid and PUVA, and PUVA alone in severe psoriasis. Br J Dermatol 1981; 104: 325-332.

57. Gollnick H, Bruer R, Brindley C, Orfanos CE, et al. Acitretin versus etretinate in psoriasis. J Am Acad Dermatol 1988; 19: 485-469.

58. Wolska H, Jablonska S, Bounameaux Y. Etretinate in severe psoriasis. J Am Acad Dermatol 1983; 9 : 883-889.

59. White SI, Marks JM, Shuster S. Etretinate in pustular psoriasis of palms and soles. Br J Dermatol 1985; 113: 58!-585.

60. Wolska H, Jablonska S, Langner A. Fraczkovvika M. Etretinate therapy in generalized pustular psoriasis (Zumbusch type). Dermatologica 1985; 171: 297-304.

61. Rubin MG, Hanno R. Short-term etretinate for pustular psoriasis. J Am Acad Dermatol 1985; 12: 896-897.

62. Chieregato GC, Leoni A. Treatment of psoriatic arthropathy with etretinate: a two year follow-up. Acta Derm Venereol (Stockh) 1986; 66: 321-324.

63. Roenigk HH Jr, Gibstine C, Glazer S, Sparberg $\mathrm{M}$ et al. Serial liver biopsies in psoriatic patients receiving long-term etretinate. Br J Dermatol 1985; 112: 77-81.

64. Camuto P, Shupack J, Orbuch P, Tobias H, et al. Long term effects of etretinate on the liver in psoriasis. Am J Surg Pathol 1987; 11: 30-37.

65. Weiss VC, Layden T, Spinowitz A, Buys CM et al. Chronic active hepatitis associatd with etretinate therapy. Br J Dermatol 1985; 112: 591-597.

66. Vahlquist $C$, Michaëlsson $G$, Vahlquist A, Vessby B. A sequential comparison of etretinate (Tigason) and isotretinoin (Roaccutane) with special regard to their effects on serum lipoproteins. Br $\mathrm{J}$ Dermatol $1985 ; 112: 69-76$.

67. Ashley JM, Lowe NJ, Borok ME, Alfin-Slater RB. Fish oil supplementation results in decreased hypertriglyceridemia in patients with psoriasis undergoing etretinate or acitretin therapy. J Am Acad Dermatol 1988; 19: 76-82.

68. DiGiovanna JJ, Helfgott RK, Gerber LH, Peck GL. Extraspinal tendon and ligament calcification associated with long-term therapy with etretinate. N Eng J Med 1986; 315: 1177-1182.

69. Kilcoyne RF. Effect of retinoids in bone. J Am Acad Dermatol 1988; 19: 212-216.

70. Ellis CN, Glbert M, Cohen KA, Albers JW, et al. Increased muscle tone during etretinate therapy. J Am Acad Dermatol 1986; 14: 907-909.

71. David M, Hodak E, Sandbank M, Gadoth N. Electromyographic abnormalities in patients undergoing long-term therapy with etretinate. J Am Acad Dermatol 1988; 19: 273-275.

72. Prendiville J, Bingham EA, Burrows D. Premature epiphyseal closure - a complication of etretinate therapy in children. I Am Acad Dermatol 1986; 15: 1259-1262.

73. Shenn DD, Azamoff DL. Clinical pharmacokinetics of methotrexate. Clin Pharmacokinet 1978;3:1-13.

74. Weinstein GD. Frost P. Methotrexate for psoriasis: a new therapeutic schedule. Arch Dermatol 1971; 103: $33-38$ 
75. Weinstein GD, Jeffes E, McCullough JL. Cytotoxic and immunologic effects of methotrexate in psoriasis. J Invest Dermatol 1990; 95: 49S-52S.

76. Roenigk HH, Auerbach R, Maibach HI, Weinstein GD. Methotrexate in psoriasis: revised guidelines. J Am Acad Dermatol 1988; 19: 145-156.

77. Gilbert SC, Klintmalm G, Menter A, Silverman A. Methotrexate induced cirrhosis requiring liver transplantation in three patients with psoriasis. Arch Intern Med 1990; 150: 889-891.

78. Zachariae H, Kragballe K, Sogeard H. Methotrexate-induced liver cirrhosis. Br J Dermatol 1980; 102: 407-412.

79. Robinson JK, Baughman RD, Auerbach R, Cimis RJ. Methotrexate hepatotoxicity in psoriasis. Arch Dermatol 1980; 116: 413-415.

80. Zachariae H, Sogaard H. Methotrexate-induced liver cirnhosis: a follow-up. Dermatologica 1987; 175: 178-182.

81. Newman M, Auerbach R, Feiner H, Holzman RS, et al. The role of liver biopsies in psoriatic patients receiving long-term methotrexate treatment. Arch Dermatol 1989; 125; 1218-1224.

82. Zachariae H, Grunnet E, Sogaard H. Liver biopsy in methotrexate-treated psoriatics: a re-evaluation. Acta Derm Venereol (Stockh) 1975; 55: 291-296.

83. Lanse SB, Amold GL, Gowans JDC, Kaplan MM. Low incidence of hepatotoxicity associated with long-term, low-dose oral methotrexate in treatment of refractory psoriasis, psoriatic arthritis, and rheumatoid arthritis: an acceptable risk/benefit ratio. Dig Dis Sci 1985; 30: 104-109.

84. Weinstein GD. Methotrexate. Ann Intern Med 1977; 86: 199-204.

85. Schein PS, Winokur SH. Immunosuppressive and cytotoxic chemotherapy. Long-term complications. Ann Intern Med 1975; 82: 84-95.

86. van Thiel DH, Ross GT, Lipsett MB. Pregnancies after chemotherapy of trophoblastic neoplasms. Science 1970; 169: 1326-1327.

87. Kaplan RL, Waite DH. Progressive interstitial lung disease from prolonged methotrexate therapy. Arch Dermatol 1978; 114: 1800-1802.

88. Soestman HD, Matthay RA, Putman CE. Methotrexate-induced pneumonitits. Medicine 1976; 55: 371-388.

89. Deck HI, Foged EK. Toxic hepatitis due to combinationtherapy with methotrexate and etretinate in psoriasis. Dermatologica 1983; 167: 94-96.

90. Weinstein GD, McCullough JL, Olsen E. Topical methotrexate therapy for psoriasis. Arch Dermatol 1989; 125: 227-230.

91. van Joost Th, Bos JD, Heule F, Meinardi MMHM. Low dose cyclosporine A in severe psoriasis. A double-blind study. Br J Dermatol 1988; 118: 183-190.

92. Ellis CN, Fradin MS, Messana JM, Brown MD, et al. Cyclosporine for plaque-type psoriasis. Results of a multidose, double-blind trial. N Eng J Med 1991; 324: 277-284.

93. de Rie MA, Meinardi MMHM, Bos JD. Analysis of side-effects of medium- and low-dose cyclosporin maintenance therapy in psoriasis. Br J Dermatol 1990; 123: 347-353.

94. Nieboer C, de Hoop D, van Loenen AC, Langendijk PNJ et al. Systemic therapy with fumaric acid derivates: New possibilities in the treatment of psoriasis. J Am Acad Dermatol 1989; 20:601-608.

95. Nugteren-Huyning WM, Schroeff JG van der, Hermans J, Suurmond D. Fumaric acid therapy for psoriasis: a randomized, double-blind, placebo-controlled study.

J Am Acad Dermatol 1990; 22: 311-312.

96. Raab W. Psoriasis-Behandlung mit Fumarsāure und Fumarsāureestern. Z Hautkr 1984; 59: 671-679.

97. Roodnat JI, Christiaans MHL, Nugteren-Huying WM, van der Schroeff JG et al. Acute nierinsufficiēntie bij patiēnten behandeld met fumaarzuuresters wegens psoriasis. Ned Tijdschr Geneesk 1989; 113: 2623-2626.

98. Baker BS, Swain AF, Griffiths CEM, Leonard JN, et al. Epidermal T lymphocytes and dendritic cells in chronic plaque psoriasis: the effects of PUVA treatment. Clin Exp Immunol 1985; 61: 526-534.

99. Baadsgaard O, Gupta AK, Taylor RS, Ellis CN, et al. Psoriatic epidermal cells demonstrate increased numbers and function of non-Langerhans antigen presenting cells. J Invest Dermatol 1989;92:190-195. 
100. Gupta AK, Baadsgaard O, Ellis CN, Voorhees JJ, et al. Lymphocytes and macrophages of the epidermis and dermis in lesional psoriatic skin, but not epidermal Langerhans cells, are depleted by treatment with cyclosporine A. Arch Dermatol Res 1989; 281: 219-226.

101. Livden JK, Nilsen R, Bjerke JR, Matre R. In situ localization of interferons in psoriatic lesions. Arch Dermatol Res 1989; 281: 392-397.

102. Griffiths CEM, Voorhees JJ, Nickoloff BJ. Gamma interferon induces different keratinocyte cellular patterns of expression of HLA-DR and DQ and intercellular adhesion molecule-1 (ICAM-1) antigens. Br J Dermatol 1989; 120: 1-7.

103. Nickoloff BJ. Role of interferon-gamma in cutaneous trafficking of lymphocytes with emphasis on molecular and cellular adhesion events. Arch Dermatol 1989; 124: 1835- 1843.

104. Gottlieb AB, Lifschitz B, Fu SM, Staiano-coico L, et al. Expression of HLA-DR molecules by kerntinocytes, and presence of Langerhans cells in the dermal infiltrate of active psoriatic pleques. J Exp Med 1986; 164: 1013-1028.

105. Baadsgaard $O$, Tong $P$, Elder JT, Hansen ER, et al. UM4D4+ (CDw60) T-cells are compartmentalized into psoriatic skin and release lymphokines that induce a keratinocyte phenotype expressed in psoriatic lesions. J Invest Dermatol 1990; 95: 275-282.

106. Pereira GMB, Miller JF, Shevach EM. Mechanism of action of cyclosporine A in vivo II. T cell priming in vivo to alloantigen can be mediated by an IL-2-independent cyclosporine A-resistant pathway.J Immunol 1990; 144: 2109-2116.

107. Kumagai N, Benedict SH, Mills GB, Gelfand EW. Cyclosporin A inhibits induction but not progression of human T cell proliferation triggered by phorbol esters and calcium ionophores. J Immunol 1988; 141: 3747-3752.

108. Emmel EA, Verweij CL, Durand DB, Higgins KM, et al. Cyclosporin A specifically inhibits function of nuclear proteins involved in T cell activation. Science 1989; 246: 1617-1620.

109. Handschumacher RE, Harding MW, Rice J, Drugge RJ. Cyclophilin: a specific cytosolic bonding protein for cylosporine A. Science 1984; 236: 544-547.

110. Takahashi N, Hayano T, Suzuki M. Peptidyl-propyl cis-trans isomerase is the cyclosporin A-binding protein cyclophilin. Nature 1989; 337: 473-475.

111. Thompson CB, Lindsten $T$, Ledbetter JA, Kunkel SL, et al. CD28 activation pathway regulates the production of multiple T-cell derived lymphokines/cytokines. Proc Natl Acad Sci USA 1989; 86: 1333-1337

112. Granelli-Piperno A, Keane M, Steinman RM. Evidence that cyclosporine inhibits cell-mediated immunity primarily at the level of the $T$ lymphocyte rather than the accessory cell. Transplantation 1988; 46: 53S-60S.

113. Moldwin RL, Lancki DW, Herold KC, Fitch FW. An antigen receptor driven, interleukin 2-independent pathway for proliferation of murine cytolytic T lymphocyte clones. J Exp Med 1986; 163: 1566-1582.

114. June $\mathrm{CH}$, Ledhetter JA, Gillespie MM, Lindsten $\mathrm{T}$, et al. T-cell proliferation involving the CD28 pathway is associated with cyclosporine resistant interleukin 2 gene expression. Mol Cell Biol 1987; 7: $4472-4481$.

115. Cooper KD, Baadsgaard O, Ellis CN, Duell E, et al. Mechanisms of cyclosporine A inhibition of antigen presenting activity in uninvolved and lesional psoriatic epidermis. J Invest Dermatol 1990; 94: 649-656.

116. Graneili-Piperno A. Lymphokine gene expression in vivo is inhibited by cyclosporine A. J Exp Med 1990; 171: 533-544.

117. Urabe A, Kanitakis J, Viac J, Thivolet J. Cyclosporin A inhibits directly in vivo keratinocyte proliferation of living human skin. J Invest Dermatol 1989; 92: 755-757.

118. Zoja $C$. Furci $L$, Ghilardi $F$, Zilio $P$, et al. Cyclosporine induced endothelial cell injury. Lab Invest 1986; $55: 455-462$.

119. Pigatto PD, Mozzanica N, Polenghi MM, Altomare GF, et al. Cyclosporine A inhibits polymorphonuclear leukocyte chemotaxis in vivo. Transpl Proc 1988; 20: 91-94. 
120. Triggiani M, Cirillo R, Lichtenstein LM, Marone G. Inhibition of histamine and prostaglandin $D_{2}$ release from human lung mast cells by ciclosporin A. Int Arch Allergy Appl Immunol 1989; 88: 253-255.

121. Bos JD, Hagenears C, Das PK, Krieg SR, et al. Predominance of "memory" T cells (CD4*, CDw29+) over "naive* T cells $\left(\mathrm{CD}^{*}, \mathrm{CD}^{*} \mathrm{R}^{*}\right)$ in both normal and diseased human skin. Arch Dermatol Res 1989; 281: 24-30.

122. Morganroth GS, Chan LS, Walter JD, Voorhees JJ, et al. Proliferating cells in psoriatic dermis are composed primarily of $\mathrm{T}$ cells, endothelial cells, and factor XIIIa + perivascular dendritic cells (Abstract). J Invest Dermatol 1990; 94: 557A

123. Horrocks C, Ormerod AD, Duncan JI, Thomson AW. Influence of systemic cyclosporin A on interleukin-2 and epidermal growth factor receptor expression in psoriatic skin lesions. Clin Exp Immunol 1989; 78: 166-171.

124. Griffiths CEM, Voorhees JJ, Nickoloff BJ. Characterization of intercellular adhesion molecule-1 and HLA-DR expression in normal and inflamed skin: modulation by recombinant gamma interferon and tumor necrosis factor. J Am Acad Dermatol 1989; 20:617-629.

125. Hancock GE, Kaplan G, Cohn ZA. Keratinocyte growth regulation by the products of immune cells. J Exp Med 1988; 168: 1395-1402

126. Bos JD, van Garderen ID, Krieg SR, Poulter LW. Different in situ distribution patterns of dendritic cells having Langerhans $\left(\mathrm{T}^{+}\right)$and interdigitating $\left(\mathrm{RFD1}^{*}\right)$ cell immunophenotype in psoriasis, atopic dermatitis and other inflammatory dermatoses. J Invest Dermatol 1986; 87: 358-361.

127. Cooper KD, Breathnach SM, Caughman SW, Palini AG, et al. Fluorescence microscopic and flow cytometric analysis of bone marrow-derived cells in human epidermis: a search for the human analogue of the murine dendritic Thy-1 ${ }^{*}$ epidermal cell. J Invest Dermatol 1985; 85: 546-552.

128. Baker BS, Lambert S, Powles AV, Valdimarsson H, et al. Epidermal DR ${ }^{+} 6^{-}$dendritic cells in inflammatory skin diseases. Acta Derm Venereol (Stockh) 1988; 68: 209-217.

129. Schopf RE, Hoffman A, Jung M, Morsches B, et al. Stimulation of $T$ cells by autologous mononuclear leukocytes and epidermal cells in psoriasis. Arch Dermatol Res 1986; 279: 89-94.

130. Korstanje MJ, van de Staak WJBM. Longterm treatment of psoriasis with cyclosporine A: Sideeffects, minimal effective dose and cyclosporin blood levels. Clin Exp Dermatol 1991; 16: 8-10

131. Ellis CN, Fradin MS, Messana JM, Brownn MD, et al. Cyclosporine for plaque-type psoriasis. Results of a multi dose, double blind trial. N Eng J Med 1991; 324: 277-284.

132. Korstanje MJ, van de Staak WJBM. Cyclosporin maintenance therapy for severe atopic dermatitis. Acta Derm Venereol (Stockh): 1991; 71: 356-357.

133. Elgart G, Stover $P$, Larson $K$, Sutter $C$, et al. Treatment of pyoderma gangrenosum with cyclosporine: results in seven patients. J Am Acad Dermatol 1991; 24: 83-86.

134. Magid ML, Gold MH. Treatment of recalcitrant pyoderma gangrenosum with cyclosporine. J Am Acad Dermatol 1989; 20: 293-294.

135. Shelley ED, Shelley WB. Cyclosporine therapy for pyoderma gangrenosum associated with sclerosing cholangitis and ulcerative colitis. J Am Acad Dermatol 1988; 18: 1084-1088.

136. Nussenblatt RB, Palestine AG, Rook $A H$, et al. Treatment of intraocular inflammatory disease with cyclosporin A. Lancet 1983; II: 235-238.

137. Graham E, Sanders MD, James DG, et al. Cyclosporin A in the treatment of posterior uveitis. Trans Ophthalmol Soc UK 1985; 104: 146-151.

138. Muftuoglu AU, Pazarli H, Yurdakul S, et al. Short-term cyclosporin A treatment of Behçet's disease. Br J Ophthalmol 1987; 71: 387-390.

139. Binder AI, Grham EM, Sanders MD, et al. Cyclosporin A in the treatment of sevee Behçet's disease. Br J Dermatol 1987; 26: 285-291.

140. BenEzra D, Cohen E, Chajek $T$, et al. Evaluation of conventional therapy versus cyclosporin $A$ in Behçet's syndrome. Transplant Proc 1988; 20: 136-143.

141. Masuda K, Nakajima A, Urayama, et al. Double-masked trial of cyclosporin versus colchicine and long-term open study of cyclosporin in Behçet's disease. Lancet 1989; I: 109-115.

142. Zachariae H. Cyclosporine A in epidermolysis bullosa acquisita. J Am Acad Dermatol 1987; 17: 1058-1059. 
143. Crow LL, Finkle JP, Gamman WR, Woodley DT. Clearing of epidermolysis bullosa scquisita with cyclosporine. J Am Acad Dermatol 1988; 18: 937-952.

144. Ho VC, Gupta AK, Ellis CN, at al. Treatment of severe lichen planus with cyclosprine. J Am Acad Dermatol 1990; 22: 64-68.

145. Higgins EM, Munro CS, Friedman PS, at al. Cyclosporin A in the treatment of lichen planus. Arch Dermatol 1989; 125: 1436.

146. Frances C, Boisnic S, Etiennne S, et al. Effect of local application of cyclosporine on chronic erosive lichen planus of the oral cavity. Dermatologica 1988; 177: 194-195.

147. Balato N, De Rosa S, Bordone F, et al. Dermatolofical application of cyclosporine. Arch Dermatol 1989; 125: 1430-1431.

148. Gupta AK, Ellis CN, Tellner DC, Voorhees JJ. Cyclosporine A in the treatment of severe alopecis areata. Transpl Proc 1988; 20: 105-108.

149. Gilhar A, Pillar T, Etzioni A. Topical cyclosporin A in alopecia areak. Acte Derm Venereol 1989; 69: 252-253.

150. Picascia DD, Roenigk HH Jr. Effects of oral and topical cyclosporine in male pattern alopecia. Transplant Proc 1988; 3: 109-111.

151. Duschet P, Schwartz T, Oppolzer G, et al. Persistent light reaction: successful treatment with cyclosporin A. Acta Derm Vebereol (Stockh) 1988; 68: 176-178.

152. Norris PG, Camp RDR, Hawk JLM. Actinic reticuloid: response to cyclosporine. J Am Acad Dermatol 1989; 21: 307-309.

153. Thestrup-Pedersen K, Zachariae C, Kaltoft $\mathrm{K}$, et al. Developinent of cutanecus pseudolymphoma following cyclosporin therapy of actinic reticuloid. Dermatologica 1988; 177: 376-381.

154. Barthelemy H, Frappaz A, Cambazard F, et al. Treatment of nine cases of pemphigus vulgaris with cyclosporine. J Am Acad Dermatol 1988; 18: 1262-1266.

155. Bondesson L, Hammar H. Treatment of pemphigus vulgaris with ciclosporin. Dermatologica 1990; 181: $308-310$.

156. Thivolet J, Barthélémy H, Rigot-Muller G, et al. Effocts of cyclosporin on bullous pemphogoid and pemphigus. Lancet 1985; 1: 334-335.

157. Cunliffe WJ. Bullous pemphigoid and response to cyclosporin. Br J Dermatol 1987; 117: 113-114.

158. Korstanje MJ, Bessems PJMJ, Hulsmans RFHJ, van de Staak WJBM. Pustular psoriasis and acrodermatitis continua (Hallopeau) need high doss of systemic cyclosporine A. Dermatologica 1989; 179:90-91.

159. Isenberg DA, Snaith ML, Morrow WJW, et al. Cyclosporin A for the treatment of systemic lupus orythematosus. Int J Immunopharmacol 1981; 3: 163-169.

160. Miescher PA. Treatment of systemic lupus erythematosus. Springer Semin Immunopathol 1986; 9: 224-237.

161. Ter Borg EJ, Tegzess AM, Kallnberg CGM. Unexpected reversible cyclosporine A-induced nephrotoxicity in a patient with systemic lupus erythematosus and tubulointerstitial renal disease. Clin Nephrol 1988; 29: 93-95.

162. Makover D, Freundlich B, Zurier RB. Relapse of systemic lupus erythematosus in a patient receiving cyclosporine A. J Rheum 1988; 15: 117-119.

163. Miescher PA, Miescher A. Combined cyclosporin-steroid treatment of systemic lupus erythematosus. In: Schindler R, ed. Cyclosporin in autoimmune diseases. New York: Springer-Verlag, 1985: 337-345.

164. Heule F, van Joost $T$, Beukers R. Cyclosporine in the treatment of lupus erythematosus. Arch Dermatol 1986; 122: 973-974.

165. Heckmatt J, Hasson N, Saunders C, et al. Cyclosporin in juvenile dermatomyositis. Lancet 1989; I: 1063-1066.

166. The HSG, Jacobs P, Houben H. Cyclosporin in the treatment of intractable polymyositis. Lancet 1984; I: $792-793$.

167. Lovi S, Hodgson HJF. Cyclosporin for dermatomyositis? Ann Rheum Dis 1989; 48: 85-86.

168. Zachariae H, Zachariae E. Cyclosporin A in systemic sclerosis. Br J Dermatol 1987; 116: 741-742.

169. Yocum DE, Wilder RL. Cyclosporine A in progressive systemic sclerosis. Am J Med 1987; 83: 369-370. 
170. Amor B, Dougados M. Cyclosporine: therapeutic effects in theumatic disenses. Transplent Proe 1988; 3: 218-223.

171. Halevy S, Weltfriend S, Pick AI, Weiss H, et al. Immunologic studies in Darier's disease. Int J Dermitol 1988; 27: 101-105.

172. Palestine AG, Nussenblatt RB, Chan C. Side-effects of systemic cyclosporine in patients undergoing transplantation. Am J Med 1984; 77: 652-656.

173. Buechner SA, Winkelman RK, Banks PM. T-cell subsets in cutaneous sarcoidosis. Arch Dermatol 1983; 119: 728-732.

174. Modlin RL, Hofman FM, Sharma OP, Gottlieb B, et al. Demonstration in situ of subsets of $T$ lymphocytes in sercoidosis. Am J Dermatopathol 1984; 6: 423-427.

175. Bieloary L, Holland C, Gascon P, Frohman L. Uveitis, cutaneous and neurosareoid: trentment with low dose cyclosporin A. Transpl Proc. 1988; 20: 144-148.

176. Halder RM, Walters CS, Johnson BA, Chakrabarti SG, et al. Aberrations in $T$ lymphocytes and natural killer cells in vitiligo: a flow cytometric study. J Am Acad Dermatol 1988; 14: 733-737.

177. Naughton NGK, Eisinger M, Bystryn JC. Detection of antibodies to melanocytes in vitiligo by specific immunoprecipitation. J Invest Dermatol 1983; 81: 540-542.

178. Ho VC, Gupta AK, Ellis CN, et al. Cyclosporine in lamellar ichthyosis. Arch Dermatol 1988; 125: 511-514.

179. Oxholm A, Thomsen $K$, Menne T. Squamous cell carcinomas in relation to cyclosporin therapy of non-malignant skin disorders. Acta Derm Venereol (Stockh) 1988; 69: 89-90.

180. Meyer P, van Voorst Vader PC. Lack of effect of cyclosporin A in pityriasis mubra pilaris. Acta Derm Venereol (Stockh) 1989; 69: 272-275.

181. Kreis W, Budman DR, Shapiro PE. Cyclosporin A (cyclosporine) in the treatment of cutaneous T cell lymphome (mycosis fungoides). J Am Acad Dermatol 1988; 18: 1138-1139.

182. Jensen JR, Thestrup-Pedersen $\mathrm{K}$, Zachariae $\mathrm{H}$, et al. Cyclosporin $A$ therapy for mycosis fungoides. Arch Dermatol 1987; 123: 160-163.

183. Totterman TH, Scheynius A, Killander A, et al. Treatment of therapy-resistant Sézary syndrome with cyclosporin A: suppression of pruritus, leukaemic T cell activation markers and tumour mass. Scand J Haematol 1985; 34: 196-203.

184. Thomsen K, Wantzin GL. Extracutaneous spreading with fatal outcome of mycosis fungopides in a patient treated with cyclosporin A: a word of caution. Dermatologica 1987; 174: 236-238. 



\title{
PART II
}

\section{CYCLOSPORINE THERAPY FOR PSORIASIS AND}

\author{
ATOPIC DERMATITIS
}



CHAPTER 1.

\title{
LONGTERM TREATMENT OF PSORIASIS WITH CYCLOSPORINE A: SIDE-EFFECTS, MINIMAL EFFECTIVE DOSE AND CYCLOSPORINE BLOOD LEVELS.
}

\author{
M.J.Korstanje, W.J.B.M.van de Stank \\ Clin Exp Dermatol 1991; 16: 8-10
}

\begin{abstract}
Fourteen patients with psoriasis received long-term treatment with cyclosporine (CsA). Among patients there was great variability in the minimal effective CsA dose. In most patients long-term treatment was limited due to dose reductions made necessary because of side-effects. The therapeutic window for CsA seems small. CsA blood levels associated with side-effects and with the minimal effective dose are in the same range and correlation between CsA blood levels and effectiveness in psoriasis is weak. Therefore, in CsA therapy for psoriasis, without concomitant medication which may influence CsA blood levels, the measurement of CsA blood levels is not necessarily helpful in optimizing therapy or preventing side-effects.
\end{abstract}




\section{INTRODUCTION}

Recent studies have shown a beneficial effect of cyclosporine A (CsA) in patients with psoriasis. ${ }^{1.2}$ However, the efficacy and tolerability of CsA as a long-term treatment have not been established, particularly as CsA can produce serious side-effects. ${ }^{3}$ We carried out a long-term study to determine the safety and tolerability of CsA. In order to optimize the therapy we also analysed the relation between C.SA trough blood levels and efficacy.

\section{METHODS}

Fourteen patients [nine female, five male, age range 32-70 years, mean ( \pm s.e.m.) duration of disease $4.8 \pm 1.04$ years] with chronic plaque psoriasis were selected. The mean (ts.e.m.) psoriasis area and severity index (PASI) ${ }^{4}$ was $29.3 \pm 2.8$. For the PASI criteria see Appendix 1. Patients with concomitant disease were excluded. Before treatment (baseline) and during CsA therapy, blood pressure, haematological and biochemical profiles were measured as well as trough (14 $\mathrm{h}$ after evening dose) levels of CsA in whole blood. The CsA blood levels were measured by a radio-immunoassay (RIA) method specific for CsA plus its metabolites and by a RIA method specific for C.SA alone without metabolites. All patients received $5.0 \mathrm{mg} / \mathrm{kg} /$ day CsA given in two doses.

If at week 4 PASI was $25 \%$ above the baseline value or when at Week 12 PASI was $10 \%$ above baseline, the therapeutic response was judged to be a failure and the patient excluded from continuing the trial.

After Week 12 the CsA dose was reduced by $0.35 \mathrm{mg} / \mathrm{kg} /$ day at monthly intervals. The CsA dose associated with the first rise in PASI was regarded as the minimal effective CsA dose. In

\section{Appendix 1: PASI criteria.}

The PASI (Psoriasis Area and Severity Index) citeria can be used as an optimal objective measure for the severity of psoriasis in an individual case.

$0.1(\mathrm{Eh}+\mathrm{IH}+\mathrm{Dh}) \mathrm{Ah}$

$0.3(\mathrm{E} t+\mathrm{It}+\mathrm{D} t) \mathrm{At}$

$0.2(\mathrm{Eu}+\mathrm{Iu}+\mathrm{Du}) \mathrm{Au}$

$0.4(\mathrm{El}+\mathrm{II}+\mathrm{DI}) \mathrm{Al}+$

Total sum $=$ PASI

$E=$ erythema

$E 0=$ no erythema

$E 1$ = slight erythema

E2 = moderate erythema

E3 = severe erythema

$\mathrm{E} 4$ = very severe erythema

$I=$ infiltrate $(10-I 4$ as with $E)$

$\mathrm{D}=$ desquamation (D0 - D4 as with $\mathrm{E}$ )

For Ah (activity head), At (activity trunc), Au (activity upper extremities), and Al (activity lower extremities) the following scores aro applied:

$0=$ not affected

$1=$ up to $10 \%$ affected

$2=10-30 \%$ affected

$3=30-50 \%$ affected

$4=50-70 \%$ affected

$5=70-90 \%$ affected

$6=90 \cdot 100 \%$ affected

PASI-score varies between 0.0 and 72.0 
order to assess the tolerability of CsA in long-term treatment we continued CsA treatment at the minimal effective dose for as long as possible. In the event of relapse (PASI $50 \%$ above baseline) the CsA dosage was increased to $5.0 \mathrm{mg} / \mathrm{kg} /$ day. After cessation of CsA treatment the patients were followed up for 3 months. The dates of appearance of the first rise in PASI, relapse and discontinuation of CsA treatment were noted,

Where there was an increase in serum creatinine of more than $30 \%$, in serum potassium above the upper limit of normal range, in serum total bilirubin or liver enzymes of more than $100 \%$ or diastolic blood pressure above $95 \mathrm{mmHg}$ on two consecutive visits, the CsA-dosage was reduced by $25 \%$. If the abnormality was not corrected within 4 weeks, a further reduction of $25 \%$ was performed. If this again did not have the desired effect CsA was withdrawn.

\section{RESULTS}

\section{Clearance}

Eleven patients responded to therapy but three out of 14 patients were rated as failures at week 12 . Nevertheless, all three had shown some improvement (See Table 1).

\begin{tabular}{|c|c|}
\hline $\begin{array}{l}\text { Table } 1 \\
\text { Failures at week } 12 \\
\text { PASI at haseline }\end{array}$ & $\begin{array}{c}\text { \% PASI reduction } \\
\text { after } 12 \text { weeks }\end{array}$ \\
& 44.2 \\
38.0 & 19.2 \\
28.6 & 24.1 \\
48.8 & \\
\hline
\end{tabular}

\section{Side-effects}

In 11 of the 14 patients the dose was reduced because of side-effects. The side-effects and the number of dose reductions are listed in Table 2.

A patient who had a history of depression 2 years previously became depressed during CsA therapy. The depression was cleared within 6 weeks after cessation of CsA therapy. One patient had joint pains affecting hands, shoulders and knees. She also felt very tired during CsA therapy. The serum urate was not increased. The joint pains and tiredness disappeared despite deterioration of the psoriasis in a 4 week period after cessation of CsA therapy. As this patient had never reported joint pains before, a relation with CsA therapy is likely.

\section{Minimal effective dose.}

The minimal effective dose was found in 11 patients. The three remaining patients were all judged as treatment failures at Week 12. Due to dose reductions, three patients reached the minimal effective dose within 12 weeks. The mean ( $t$ s.e.m.) minimal effective dose of these 11 patients was $3.0 \pm 0.23 \mathrm{mg} / \mathrm{kg} /$ day (range $1.6-3.9$ ). 


\begin{tabular}{|c|c|c|}
\hline Side-effect & $\begin{array}{l}\text { No.of } \\
\text { patients }\end{array}$ & $\begin{array}{l}\text { No. of dose } \\
\text { reductions }\end{array}$ \\
\hline $\begin{array}{l}\text { Serum creal. } 30 \% \\
\text { bovo baseline value }\end{array}$ & 6 & 7 \\
\hline $\begin{array}{l}\text { Potassium above upper } \\
\text { limit of normal range }\end{array}$ & 2 & 3 \\
\hline $\begin{array}{l}\text { Bilinubin > } 2 x \text { upper } \\
\text { limit of normal range }\end{array}$ & 1 & - \\
\hline $\begin{array}{l}\text { OT }>2 x \text { upper limit } \\
\text { of normal rango }\end{array}$ & 1 & - \\
\hline Hypertension & 2 & 2 \\
\hline Hypertrichosis & 3 & 1 \\
\hline Tremor & 2 & - \\
\hline Paraesthesia & 2 & - \\
\hline Depression & 1 & - \\
\hline Joint pains & 1 & 1 \\
\hline Tiredness & 1 & 1 \\
\hline \multicolumn{3}{|c|}{$\begin{array}{l}\text { In some patients more then one side-effect was } \\
\text { observed and sometimes two dose-reductions were } \\
\text { necessary to correct one side-effect }\end{array}$} \\
\hline
\end{tabular}

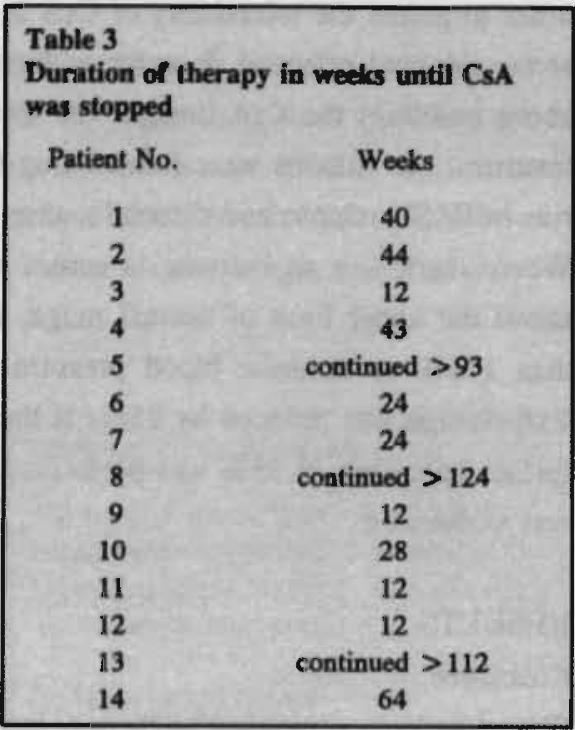

\section{Long term treatment}

After 12 weeks, 10 patients continued the study (one patient discontinued medication for personal reasons). Three patients have continued CsA for over 2 years. The remaining seven patients relapsed after dose reduction for side-effects. After CsA was restarted in a dosage of 5.0 $\mathrm{mg} / \mathrm{kg} /$ day, serious side-effects recurred rapidly and the psoriasis failed to clear within 4 weeks. CsA was therefore discontinued. In the follow-up period all side-effects disappeared completely. The duration of therapy in the weeks up to the discontinuation of CsA medication is listed in Table 3.

\section{CSA blood levels}

Mean ( \pm s.e.m.) CsA blood levels, with and without metabolites, at Week 4 were $423 \pm$ 83 and $163 \pm 26 \mathrm{ng} / \mathrm{ml}$ respectively. Mean CsA blood levels with and without metabolites, at Week 12 were $262 \pm 43$ and $113 \pm 16 \mathrm{ng} / \mathrm{ml}$, respectively. No correlation was found between CsA dose and trough CsA blood level with and without metabolites at Week $4(r=0.21$ and 0.24 , respectively) or at Week $12(r=0.31$ and 0.20 , respectively). No correlation existed between CsA dose and PASI reduction at Week $12(r=0.13)$ nor between mean CsA dose of the first 12 weeks and PASI reduction at Week $12(r=0.09)$. 
Correlations between PASI reduction at Week 12 and CsA blood levels with and without metabolites were 0.10 and 0.35 , respectively.

Mean CsA blood levels with and without metabolites at which serum creatinine $130 \%$ above baseline or serum potassium above the upper limit of normal occurred were $655 \pm$ $79 \mathrm{ng} / \mathrm{ml}$ (range $255-1110$ ) and $232 \pm 24 \mathrm{ng} / \mathrm{ml}$ (range 125-340), respectively.

\section{DISCUSSION}

CsA is effective in psoriasis but among patients there appears to be a great variability in the minimal effective dose $(1.6->5.0 \mathrm{mg} / \mathrm{kg} /$ day). No criteria are available to select patients who will respond to lower CsA doses.

The number of patients that could be maintained on CsA was low compared to the study of Griffiths et al. ${ }^{5}$ In most patients long term treatment was limited by dose reductions which were necessary because of side-effects. The mean CsA blood level at which sideeffects occurred was only slightly higher than the mean CsA blood level at the minimal effective dose. The therapeutic window for CsA is therefore probably small. We found a mean minimal effective dose of $3.5 \mathrm{mg} / \mathrm{kg} /$ day. This is only slightly lower than 4.6 $\mathrm{mg} / \mathrm{kg} /$ day which caused irreversible kidney damage in transplant recipients. ${ }^{6}$ However, these transplant recipients received relatively high doses of CsA in the immediate posttransplant period, but were maintained on about $5 \mathrm{mg} / \mathrm{kg} /$ day for months 3-12 after transplantation, without further dose reduction in the presence of reduced glomerular filtration rates. Further long-term studies are necessary to determine the safety of CsA therapy in psoriasis.

We did not observe any correlation between CsA dosage and therapeutic effect, nor was there a correlation between CsA dose and blood level. This is consistent with previous reports in renal- transplant recipients. ${ }^{7}$ Since there is only a weak correlation between CsA blood level and therapeutic efficacy in psoriasis, blood levels cannot now be used to optimize CsA therapy in psoriasis. However, the most serious side-effect, renal dysfunction, does seem to be related to CsA concentration. ${ }^{8,9}$

Hence, in renal-transplant patients, regular trough CsA level estimations are strongly recommended. ${ }^{7,8}$ The risk of renal dysfunction increases rapidly above a CsA trough blood level of $200 \mathrm{ng} / \mathrm{ml}$ without metabolites. ${ }^{9.10}$ Most psoriasis patients have a minimal effective CsA dose below $4.0 \mathrm{mg} / \mathrm{kg} / \mathrm{day}$ and a corresponding CsA trough blood level below $200 \mathrm{ng} / \mathrm{ml}$. We have shown that CsA blood levels at the minimal effective dose are slightly lower than those in patients with side-effects. 


\section{REFERENCES}

1. van Joost Th, Bos JD, Heule F, Meinardi MMHM. Low-dose cyclosporin A in severe psoriasis. A double-blind study. $\mathrm{Br}$ J Dermatol 1988: 118; 183-190.

2. Ellis CN, Gorsulowsky DC, Hamitton TD, Billings JK, et al. Cyclosporine improves psoriasis in a double blind study. JAMA 1986: 256; 3110-3116.

3. von Graffenried B, Knupp P. Side effects of cyclosporine (Sandimmur (b) $^{k}$ )in renal transplant recipients and in patients with autoimmune disease. Transpl Proc 1986: 18; 876-883.

4. Fredriksson T, Pettersson U. Severe psoriasis - oral therapy with a new retinoid. Dermatologica 1978; 157: 238-241

5. Griffiths CEM, Powles AV, McFadden J, Baker BS et al. Long-term cyclosporin for psoriasis. Br J Dermatol 1989; $120: 253-260$

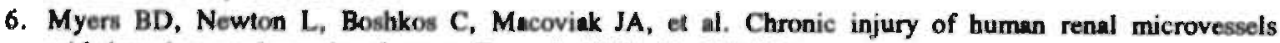
with low-dose cyclosporine therapy. Transpl. 1988: 46; 694-703.

7. Takada K, Yoshikmwa H, Muranishi $S$, Nagano $S$ et al. A preliminary pharmacokinetic study of cyclosporine $A$ in 10 japanese renal transplant patients. Int J Clin Pharmacol Ther Toxicol 1987; 25: $438-442$

8. Königsrainer A, Wohlfahrter T, Spielberger M, Bōsmüller C, et al. Rigid-dose regimen versus blood level-adjusted cyclosporine in elderly cadaveric renal allograft recipients. Transpl Proc 1988; Vol XX, No 2, Suppl 2: 426-427.

9. Kennedy MS, Yee GC, McGuire TR, Leonard TM et al. Correlation of serum cyclosporine concentration with renal dysfunction in marrow transplant recipients. Transplentation 1985; 40: 249-253.

10 Keown PA, Stiller CR, Sinclair NR, Carruthers $G$ et al. The clinical relevance of cyclosporine blood levels as measured by radioimmunonssay. Transpl Proc 1983; vol. XV Suppl. 1; 2438-2441. 


\title{
CHAPTER 2.
}

\section{PUSTULAR PSORIASIS AND ACRODERMATITIS CONTINUA (HALLOPEAU) NEED HIGH DOSES OF SYSTEMIC CYCLOSPORINE A.}

\author{
M.J.Korstanje, P.J.M.J.Bessems, R-F.H.J.Hulsmans, W.J.B.M.ven de Stuak \\ Dermatologica 1989; 179: 90-91
}

The effectiveness of cyclosporine A (CsA) in severe plaque psoriasis was shown in several studies. ${ }^{1-4}$ We present here a case of therapy resistent generalized pustular psoriasis and acrodermatitis continua in which treatment with CSA produced a reduction of the cutaneous lesions.

\section{CASE REPORT}

A 61-year-old man had suffered form generalized pustular psoriasis and acrodermatitis continua (Hallopeau) since 1985. There was no respons to topical therapy with class IV corticosteroid cremes in combination with psoralens plus ultraviolet $\mathrm{A}$ or in combination with topical methotrexate or oral methotrexate $15 \mathrm{mg}$ once a week. In 1986 there were two periods in which diffuse erythroderma developed. The only effective therapy turned out to be prednisone $50 \mathrm{mg} /$ day. Tapering off this dose resulted in exacerbation of psoriasis.

During a third period with diffuse erythroderma, oral treatment with CsA $8.0 \mathrm{mg} / \mathrm{kg} /$ day (blood CsA concentration $600 \mathrm{ng} / \mathrm{ml}$ ) was started in combination with prednisone 10 $\mathrm{mg} /$ day. Within 3 weeks the skin was completely clear but severe nail lesions remained. Tapering off CyA to $5.0 \mathrm{mg} / \mathrm{kg} /$ day (blood CsA concentration $350 \mathrm{ng} / \mathrm{ml}$ ) resulted in an exacerbation of acrodermatitis continua on fingers and toes within 2 weeks while pustular pustular psoriasis came back on hands and lower arms. With CsA $8.0 \mathrm{mg} / \mathrm{kg} /$ day the lesions cleared again except for nail lesions. Tapering off prednisone below $7.5 \mathrm{mg} /$ day resulted in exacerbation of pustular psoriasis.

We concluded CsA was effective but a high dose was needed to clear the skin completely. Without prednisone the CsA dose needed would be higher. To prevent development of renal impairment due to CsA we did not increase CsA dose above $8.0 \mathrm{mg} / \mathrm{kg} / \mathrm{day}$. 


\section{COMMENTS}

Generalised pustular psoriasis and acrodermatitis continua are serious forms of psoriasis. The management of these conditions cause many difficulties. In our patient the lesions did not respond to any form of therapy except for prednisone and CsA.

In severe plaque form psoriasis CsA $5.0 \mathrm{mg} / \mathrm{kg} /$ day is able to produce a dramatic reduction of the cutaneous lesions. ${ }^{14}$ In our patient with generalized pustular psoriasis and acrodermatitis continua CsA $5.0 \mathrm{mg} / \mathrm{kg} /$ day had no effect. CsA $8.0 \mathrm{mg} / \mathrm{kg} /$ day (bloodconcentration $600 \mathrm{ng} / \mathrm{ml}$ ) was able to clear skin lesions only in addition to prednisone 7.5 $\mathrm{mg} /$ day. For clearance of skin lesions by CsA as monotherapy a high-dose cyclosporine would be needed. Such a dose can cause renal impairment. ${ }^{3}$

Our findings are consistent with those of Zachariae and Thestrup-Pedersen, ${ }^{6}$ who treated acrodermatitis continua with CsA $14 \mathrm{mg} / \mathrm{kg} /$ day reduced to $7.5 \mathrm{mg} / \mathrm{kg} /$ day. Meinardi et al ${ }^{7}$ described a patient with generalized pustular psoriasis responsive to monotherapy CsA $12 \mathrm{mg} / \mathrm{kg} /$ day but unresponsive to CsA $5 \mathrm{mg} / \mathrm{kg} /$ day. With the dose of CsA $12 \mathrm{mg} / \mathrm{kg} /$ day renal impairment developed within a short time.

Since monotherapy CsA for generalized pustular psoriasis and acrodermatitis continua requires a CsA dose which can cause renal impairment within a short time, long-term treatment with CsA as monotherapy is not possible.

\section{REFERENCES.}

1. Van Joost Th, Heule F, Stolz E, Beukers R. Short-term use of Cyclosporin A in severe psoriasis. Br J Dermatol 1986;114:615-20.

2. Griffiths CEM, Powles AV, Leonard JN, Fry L. Clearance of psoriasis with low dose cyclosporin. Br Med J 1986;293:731-2.

3. Ellis CN, Gorsulowsky DC, Hamilton TA, Billings JK et al. Cyclosporine improves psoriasis in a double-blind study. JAMA 1986;256:3110-16.

4. Van Joost Th, Bos JD, Heule F, Meinardi MMHM. Low-dose cyclosporin A in severe psoriasis. A double-blind study. Br J Dermatol 1988;118:183-90.

5. Palastine A, Nussemblatt $R$, Chan C. Side-effects of systemic cyclosporin in patients not undergoing transplantation. Am J Med 1984;77:652-656.

6. Zachariae $\mathrm{H}$, Thestrup-Pedersen K. Ciclosporin A in Acrodermatitis continus. Dermatologica 1987; $175: 29-32$.

7. Meinandi MMHM, Westerhof W, Bos JD. Generalized pustular psoriais (von Zumbusch) responding to cyclosporin A. Br J Dermatol. 1987;116:269-70. 
CYCLOSPORINE MAINTENANCE THERAPY FOR

SEVERE ATOPIC DERMATITIS.

M.J.Korstanje and W.J.B.M.van do Staak Acta Derm Venereol.(Stockh) 1991; 71:356-357

\begin{abstract}
Twelve patients with chronic severe atopic dermatitis were treated with cyclosporine $A$ (CsA) in a dose of $5.0 \mathrm{mg} / \mathrm{kg} /$ day. All patients except one showed a good therapeutic response. After week six the CsA dose was lowered until an increase in atopic dermatitis was noticed (minimal effective dose). The minimal effective dose fluctuated with the severity of the atopic dermatitis. The mean minimal effective dose was approximately 4.0 $\mathrm{mg} / \mathrm{kg} /$ day. Maintenance therapy with CsA for atopic dermatitis seems to be effective but may be hampered by side-effects in the same way as CsA therapy is hampered by sideeffects in treatment of psoriasis.
\end{abstract}




\section{INTRODUCTION}

The therapeutic value of oral cyclosporine A (CsA) in atopic dermatitis has been reported. ${ }^{1-2}$ However, atopic dermatitis flares after discontinuation of CsA. ${ }^{2}$ Therefore, in case of chronic severe atopic dermatitis maintenance therapy with CsA seems to be necessary. We carried out an open trial to determine the minimal effective dose (MED) and effectiveness of CsA in long term treatment for atopic dermatitis.

\section{METHODS}

Six men and six women with ages ranging from 20 to 68 years were selected. They all fulfilled the diagnostic criteria for atopic dermatitis. ${ }^{3}$ At least $30 \%$ of the total skinsurface was involved, the eczentia was recalcitrant to conventional therapies and was chronic for at least a year. Topical- and systernic therapies or ultraviolet therapy had been discontinued 2 weeks prior to treatment with CsA. During CsA therapy no topical or oral concomitant medication was allowed except for non-steroid-containing emollients.

Before starting treatment (baseline) and during CsA therapy blood pressure, haematological and biochemical profiles were measured. The rule of nines was used for scoring the eczema extension. The severity of the eczema for erythema, papulae, vesiculae, xerosis, induration, excoriations, and pruritus was assessed in the face and neck, cubital fossae, hands, and back of the knees. The severity of each of these features was scored on a four-point-scale $(0=$ none, $1=$ mild, $2=$ moderate, 3 =severe). The eczema severity index was obtained by adding the numbers of each of the feature. These assessments were done at baseline, week 1, 2, 3, 4 and biweekly thereafter.

In our opinion the eczema extension score has a low correlation with the severity of the eczema. Due to e.g. a widespread erythema the eczema extension score may remain high while the patient and investigator believe that the eczema improved dramatically. Therefore we only used the eczema severity index to obtain the percentage of improvement in the eczema.

All patients received oral CsA (Sandimmune) at a dose of approximately $5.0 \mathrm{mg} / \mathrm{kg} / \mathrm{day}$ in galenical capsules containing $25 \mathrm{mg}$ or $100 \mathrm{mg}$ CsA. In case of side-effects, e.g. diastolic blood pressure above $95 \mathrm{mmHg}$ or rise in serum creatinine, CsA was withdrawn. After week $6 \mathrm{CsA}$ dose was decreased weekly with $25 \mathrm{mg}$ until progression of atopic dermatitis was observed (MED). The patients were treated with the MED as long as possible. For the patients who could be treated with a CsA dose below $5 \mathrm{mg} / \mathrm{kg} /$ day after week 6 and who were on MED for at least 8 weeks the mean MED during the last 8 
weeks of CsA therapy was calculated. This mean MED of each patient was used to calculate the mean MED of the whole group of patients.

\section{RESULTS}

In all patients except one a substantial improvement of the atopic dermatitis was observed within 4 weeks. In one patient the atopic dermatitis deteriorated despite CsA therapy and CsA was withdrawn at week 3 .

At week 6 atopic dermatitis was improved $75 \%$ or more in six patients and improved 50$75 \%$ in five patients according to the degree of involvement at baseline. However, xerosis remained a problem in all patients. At week $6 \mathrm{CsA}$ was withdrawn in one patient because of hypertension RR $185 / 110 \mathrm{mmHg}$. Another patient stopped Cs.A because he wanted to use CsA only during exacerbations of his atopic dermatitis and not as a maintenance therapy.

The severity of the atopic dermatitis fluctuated despite CSA therapy. Therefore it was difficult to obtain the MED in the remaining nine patients. In two patients with improvement of atopic dermatitis of $55 \%$ and $60 \%$ at week 6 respectively, the atopic dermatitis deteriorated with a lower dose of CsA than $5.0 \mathrm{mg} / \mathrm{kg} /$ day. In the other seven patients the mean MED obtained was $4.06 \mathrm{mg} / \mathrm{kg} /$ day (SD .732). However, MED fluctuated with the severity of the atopic dermatitis. The average fluctuation for each patient was 0.3 $\mathrm{mg} / \mathrm{kg} /$ day up or below the assessed MED. In none of the patients the fluctuation exceeded $0.5 \mathrm{mg} / \mathrm{kg} /$ day up or below the assessed MED. CsA remained effective during maintenance therapy for 19-32 weeks (mean 24 weeks).

\section{DISCUSSION}

Eleven out of twelve patients observed improvement in atopic dermatitis during CsA therapy. The MED of CsA in this group was approximately $4.0 \mathrm{mg} / \mathrm{kg} /$ day. This is higher than the MED for psoriasis. ${ }^{4}$ The MED in patients with less severe atopic dermatitis may be lower. Long-term CsA therapy for atopic dermatitis is effective but it is likely that maintenance therapy with CsA for atopic dermatitis will be hampered by side-effects in the same way as CsA therapy for psoriasis is hampered by side-effects. ${ }^{5}$ In our opinion in CsA therapy for atopic dermatitis the same safety guidelines as for CsA therapy of psoriasis should be followed. ${ }^{6}$

Since CsA is effective in atopic dermatitis it may also be used as a short-term therapy during severe exacerbations of atopic dermatitis. 


\section{REFERENCES}

1. Wahlgren C.-F. Scheynius A, Hägermark O. Antipruritic: effect of oral cyclosporin A in atopic dermatitis. Acta Derm Venereol (Stockh) 1990; 70: 323-329.

2. Tuylor RS, Cooper KD, Headington JT, Ho VC, Ellis CN, et al. Cyclosporine therapy for severe atopic dermatitis. J Am Acad Dermatoll 1989; 21: 580-583.

3. Hanifin JM, Rajka O. Diagnostic features of atopic dermatitis. Acta Derm Venereol (Stocikh) 1980; (Suppl) 92: 44-47.

4. Griffiths CEM, Powles AV, McFidden J, Baker BS, et al. Long-term cyclosporin for psoriasis. Br J Dermatol 1989; 120: 253-260.

5. de Rie MA, Meinardi MMHM, Bos JD. Analysis of side-effects of medium- and low-dose cyclosporinmaintenance therapy in psorissis. Br J Deirmatol 1990; 123: 347-353.

6. Anonymus. A consensus report: cyelosporin A therapy for psoriasis. Br J Dermatol 1990; 122 (Suppl 36): 1-3. 


\section{PART III}

HOW TO IMPROVE THE RISK-BENEFIT RATIO OF CYCLOSPORINE THERAPY FOR PSORIASIS 


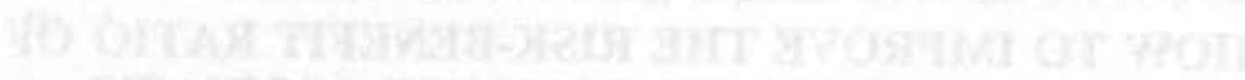

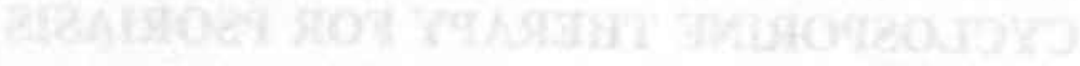




\section{CHAPTER 1.}

\section{INTRODUCTION}

Therapy with cyclosporine (CsA) is restricted by side-effects especially time- and dose related nephrotoxicity and hypertension. ${ }^{1}$ Therefore ways to improve the risk-benefit ratio of CsA therapy have to be found. Since topical therapy with CsA is not effective, ${ }^{2}$ improvement of the risk-benefit ratio must theoretically be achieved by improvement of dose-regimens, combination therapy with another therapy for psoriasis or combination therapy with a treatment that may influence the pathogenesis of the most important sideeffect(s) of CsA. Each of these possiblities is discussed below.

CsA-induced renal function loss will be discussed in part IV.

1. de Rie MA, Meinardi MMHM, Bos JD. Analysis of side-effects of medium= and low-dose cyclosporin maintenance therapy in psoriasis. Br J Dermatol 1990; 123: 347-353.

2. Bousema MT, Tank B, Heule F, Naafs B, et al. Placebo controlled study of psoriasis patients treated topically with a 10\% cyclosporine gel. J Am Acad Dermatol 1990; 22: 126-127. 


\section{CHAPTER 2.}

\section{DOSE-REGIMENS CYCLOSPORINE A ADMMNISTRATION IN}

DERMATOLOGY; ONCE A DAY OR IN FRACTIONAL DOSES?

\section{INTRODUCTION}

Recent studies have shown a beneficial effect of cyclosporine A (CsA) in patients with psoriasis.2.3 However, CsA has serious side-effects, which include acute hepatotoxicity, acute and chronic nephrotoxicity, hirsutism, hypertension and toxic effects on the central nervous system. Even a CsA dose of $4.6 \mathrm{mg} / \mathrm{kg} /$ day may cause chronic injury of the kidneys. ${ }^{6}$

Perhaps, in dermatology, it is possible to prevent side-effects with less frequent administration of CsA, while the therapeutic effect on the skin is maintained or increased. Therefore, we tried CsA administration once day.

\section{METHODS}

Patients with severe plaque-form psoriasis, resistent to conventional anti-psoriatic therapy (topical therapy including steroids, systemic therapy with retinoids, or PUVA) were selected. Patients with an increased risk for malignancy, impaired renal function (serum creatinine above 100 micromol/l), hypertension, impaired liver function, malabsorption syndrome, drug or alcohol abuse were excluded. The patients were randomly divided in two groups. Both groups had CsA therapy with the oral solution Sandimmune (100 $\mathrm{mg} / \mathrm{ml}$ ) for 8 weeks. Group A had $4.0 \mathrm{mg} / \mathrm{kg} /$ day CsA in one dose a day, group B had $4.0 \mathrm{mg} / \mathrm{kg} /$ day $\mathrm{CsA}$ divided in two doses a day. None of the patients had concomitant medication.

Clinical evaluation of psoriasis before and during therapy was carried out using the Psoriasis Area and Severity Index (PASI). ${ }^{3}$ Full blood count, serum creatinine, serum potassium, ASAT, ALAT, gammaGT, alk. fosfatase and blood pressure were measured at weekly intervals.

\section{RESULTS AND DISCUSSION}

Except for nephrotoxicity no side-effects occurred. PASI scores and serum creatinine before and after treatment are given in Table 1.

The PASI score in group A (mean 24.9), was less than in group B (mean 30.9). 


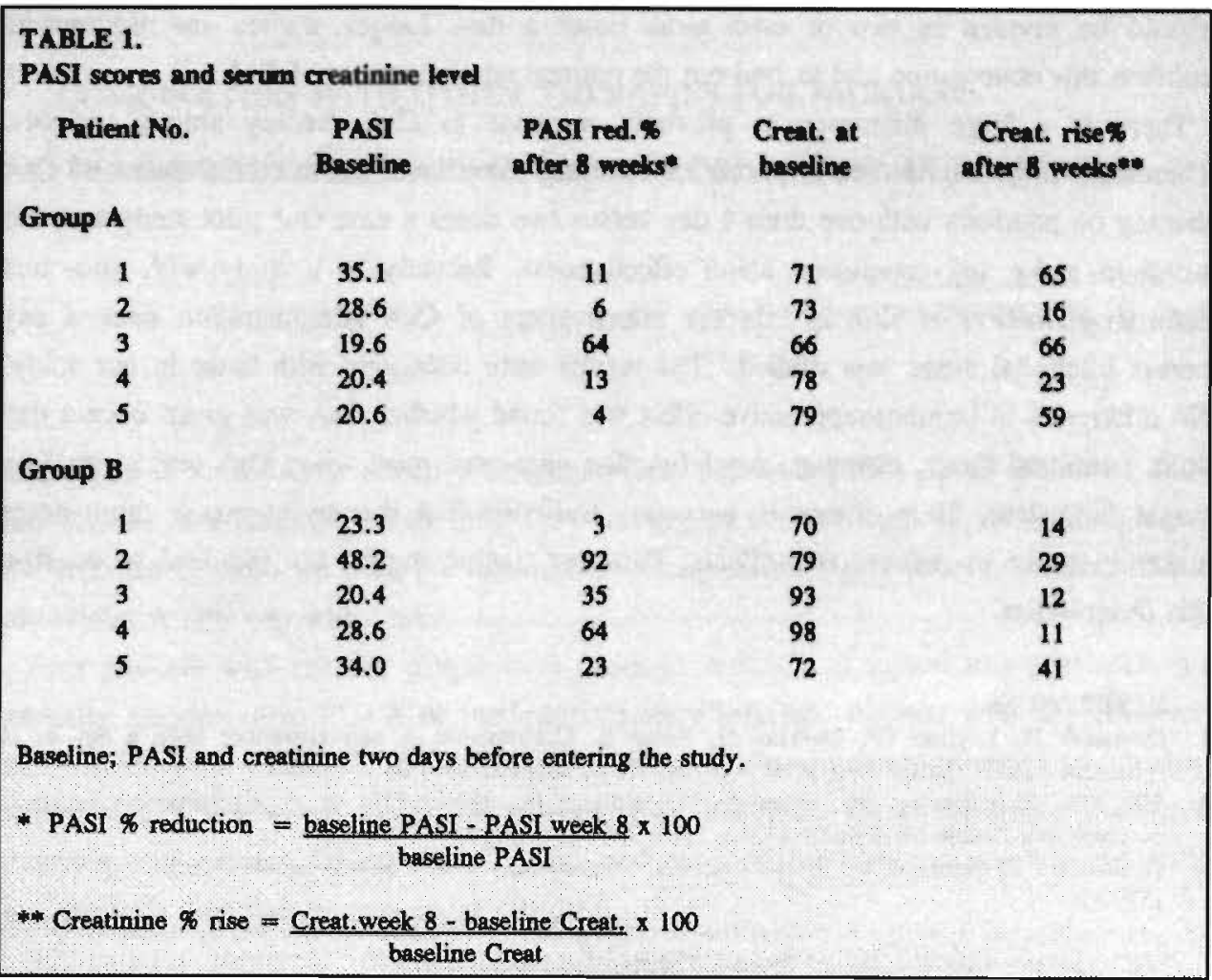

However, the reduction in the PASI score after 8 weeks in group A (19.6\%) was less than in group B (43.4\%). In all patients from both groups a rise in serum creatinine was observed. Rise in serum creatinine in group A (mean $45.8 \%$ ) was higher than in group B (mean $21.4 \%$ ). Since we studied a small group of patients our results are not significant.

All our patients developed renal impairment during CsA therapy. This shows that the therapeutic window for CsA is very small. After discontinuation of CsA renal function normalised in all patients. Acute CsA nephrotoxicity is completely reversible. However, chronic CsA nephrotoxicity after long-term treatment can be irreversible. Since irreversible renal impairment may develop, ${ }^{6}$ there is only a limited indication for CsA therapy in dermatology.

Renal function decreased more with CsA therapy in one dose a day, than with CsA therapy in two doses a day. Perhaps side-effects correlate more with CsA peak blood level than with CsA trough blood level. This may imply that no benefit can be expected from CsA administration in less than two administrations a day. CsA administration 
should be divided in two or even more doses a day. Larger studies are required to confirm this observation and to find out the optimal administration of CsA.

There is a large difference in psoriasis response to CsA therapy among patients. Therefore, large studies are required to make any conclusion about effectiveness of CsA therapy on psoriasis with one dose a day versus two doses a day. Our pilot study was too small to make any conclusion about effectiveness. Recently in a study with allo- and autotransplantation of skin in rats the effectiveness of CsA administration once a day versus fractional doses was studied.' The results were consistent with those in our study. No difference in immunosuppressive effect was found whether CsA was given once a day or in fractional doses, however, renal function decreased most when CsA was given as a single daily dose. Thus, it may be necessary to divide CsA therapy in two or more doses a day in order to prevent side-effects. However, larger studies are required to confirm this observation.

\section{REFERENCES}

1. Dieperink H, Loyssac PP, Starklint H, Kemp E. Cyclosporine A edministration: once a day or in fractional doses? Transpl Proc 1988: Vol XX, No 2, Suppl 2; 703-706.

2. Ellis CN, Gorsulowsky DC, Hamilton TD, Billings JK, Brown MD, et al. Cyclosporine improves psoriasis in a double-blind study. JAMA 1986: 256; 3110-3116.

3. Fredriksson T, Petterson U. Severe psoriasis - oral therapy with a new retinoid. Dermatologica 1978: $157 ; 238$.

4. von Graffenried B, Krupp P. Side effects of cyclosporine (Sandimomun(R)) in renal transplant recipients and in patients with autoimmune disease. Transpl Proc 1986: 18; 876-883.

5. van Joost Th, Bos JD, Heule F, Meinardi MMHM. Low-dose cyclosporin A in severe psoriasis. A double-blind study. Br J Dermatol 1988: 118; 183-190.

6. Myers BD, Newton L, Boshkos C, Macoviak JA, et al. Chronic injury of human renal microvessels with low-dose cyclosporine therapy. Transpl. 1988: 46; 694-703. 


\section{CHAPTER 3.}

\section{COMBINATION WITH OTHER THERAPIES FOR PSORIASIS}

\subsection{COMBLNATION THERAPY CYCLOSPORINE A - PIVA IN PSORIASIS.}

M.J. Korstanje, R.F.H.J.Hulsmans Acta Dem Venereol (Stockh) 1990; 70; 89-90

Cyclosporine A (CsA) is effective in plaque-form psoriasis (1 fro Ref.). However, CsA has serious side-effects, ${ }^{2}$ which limit CsA therapy in dermatology. In order to improve the risk-benefit ratio we tried a combination therapy consisting of psoralens and artificial ultraviolet A (PUVA) with CsA.

Four patients with chronic plaque-form psoriasis resistant to topical anti-psoriatics and partially responsive to PUVA or methotrexate were selected. Patients with any concomitant disease were excluded. Before initiating treatment (baseline) and during CsA therapy, haematologic parameters, serum electrolytes, liver enzymes, serum creatinine and blood pressure values were determined. Clinical evaluation of psoriasis was carried out using the psoriasis area and severity index (PASI). ${ }^{3}$

All patients received $5.0 \mathrm{mg} / \mathrm{kg} /$ day CsA (oral solution Sandimmun ${ }^{(\mathrm{R})} 100 \mathrm{mg} / \mathrm{ml}$ ) divided into two doses per day. In case of side effects the CsA dose was reduced by $25 \%$. When the PASI had declined to $25 \%$ from baseline or more, the CsA dose was reduced by $1.0 \mathrm{mg} / \mathrm{kg} /$ day every 4 weeks until an increase in PASI was observed. In the case of relapse (PASI score above 50\% from baseline), PUVA was added. For PUVA therapy we used the same protocol as the United States Cooperative Clinical Trial Study. ${ }^{4}$ When after 8 weeks of CsA therapy, PASI was still higher than $25 \%$ from baseline, we regarded CsA monotherapy ineffective and PUVA was added.

\section{RESULTS AND DISCUSSION}

The results are listed in table 1 and 2 . All patients required a daily CsA dose higher than $3.0 \mathrm{mg} / \mathrm{kg} /$ day and no additive effect from PUVA to CsA therapy was observed. In patients 1, 2, and 3, psoriasis exacerbated despite PUVA being added to CsA therapy. In patient no.4, combination therapy CsA-PUVA was effective. In the latter, however, after discontinuing CsA therapy, psoriasis could be controlled with PUVA alone. Therefore it is likely that only PUVA was responsible for the effect on psoriasis. 
In patients treated with immunosuppressive drugs including CsA, a high incidence of cutaneous malignancies associated with sun exposure ${ }^{5}$ has been reported. Since CsA is

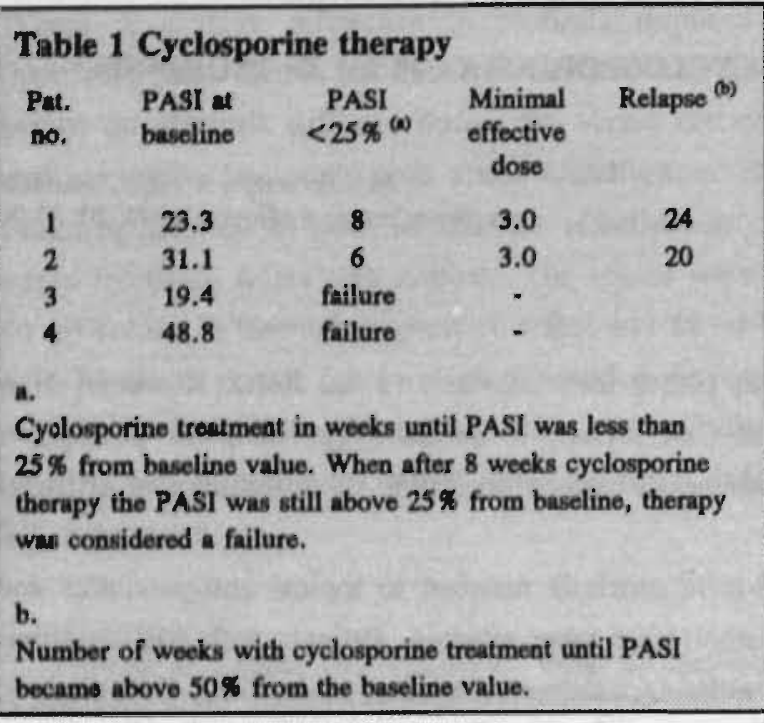

capable of promoting the survival and progression of UV-induced skin tumours ${ }^{6}$ it is likely that the increased risk of cutaneous squamous cell carcinomas in PUVA therapy ${ }^{7}$ is potentiated by CsA. Rapid growth of squamous cell carcinomas has been observed in patients treated with CsA for psoriasis. $^{8}$ Therefore, the combination therapy CsA-PUVA should be avoided until a beneficial additive effect from PUVA in CsA therapy is proven.

\section{Table 2}

Cyclosporine-PUVA combination therapy

\begin{tabular}{|c|c|c|c|c|c|c|}
\hline $\begin{array}{l}\text { Pat. } \\
\text { no. }\end{array}$ & $\begin{array}{l}\text { PASI } \% \text { before } \\
\text { PUVA therapy }{ }^{(a)}\end{array}$ & $\begin{array}{c}\text { weeks } \\
\text { CsA-PUVA }\end{array}$ & $\begin{array}{l}\mathrm{CsA} \\
\text { dose }\end{array}$ & $\begin{array}{l}\text { Side- } \\
\text { effects }\end{array}$ & $\begin{array}{l}\text { PASI } \% \\
\text { at the } \\
\text { end }\end{array}$ & $\begin{array}{l}\text { Cumul. } \\
\text { UVA dose } \\
\text { J } \mathrm{cm}^{2}\end{array}$ \\
\hline 1 & 54 & 6 & 3.0 & - & 86 & 5.6 \\
\hline 2. & 51 & 8 & 3.0 & creat. $\uparrow$ & 68 & 4.9 \\
\hline 3 & 69 & 16 & $5.0 / 3.5^{(b)}$ & creat. $\uparrow$ † & 89 & 208.1 \\
\hline 4 & 47 & 6 & 5.0 & - & 0 & 93.0 \\
\hline P & $\begin{array}{l}\text { from baseline val } \\
\text { dose reduction fo }\end{array}$ & $\begin{array}{l}\text { yee Table 1) } \\
\text { ide-effects }\end{array}$ & & & & \\
\hline
\end{tabular}

\section{REFERENCES}

1. van Joost T, Bos JD, Heule F, Meinardi MMHM. Low-dose cyclosporin A in severe psoriasis. A double blind study. Br J Dermatol 1988: 118; 183-190.

2. von Graffenried B, Krupp P. Side effects of cyclosporine (Sandimmun ${ }^{(R)}$ ) in renal transplant recipients and in patients with autoimmune disease. Transpl Proc 1986: 18; 876-883.

3. Fredriksson T, Pettersson U. Severe psoriasis - oral therapy with a new retinoid. Dermatologica 1978: $157 ; 238-244$.

4. Hōnigsmann $H$, Jaschke $E$, Gschnait $F, B$ renner $W$ et al. 5-Methoxypsoralen (Bergapten) in photo chemotherapy of psoriasis. Br J Dermatol 1979: 101; 369-378.

5. Maize JC. Skin cancer in immunosuppressed patients. Editorial. JAMA 1977: 237; 1857-1858.

6. Servilla KS, Bumham DK, Daynes RA. Ability of cyclosporin to promote the growth of transplanted ultraviolet radiation induced tumours in mice. Transplantation 1987; 44: 291-295. 
7. Stern RS, Lange R. Non-melanoma skin cancer occurring in patients treated with PUVA five to ten years after first treatment. J Invest Dermatol 1988: 91; 120-124.

8. Oxholm A, Thomsen $K$, Menne $T$. Squamous cell carcinomas in relation to cyclosporin therapy of non malignant skin disorders. Actu Derm Venereol (Stockh) 1989; 69; 89-90. 


\section{ABSTRACT}

Five patients with therapy-resistant plaque-type psoriasis were treated with cyclosporine. In cases where cyclosporine was not effective or in cases of relapse, etretinate was added. No additive therapeutic effect of etretinate was observed.

\section{INTRODUCTION}

Recent studies have shown a beneficial effect of cyclosporine A (CsA) in patients with psoriasis. ${ }^{1,2} \mathrm{CsA}$ has serious side-effects, which include hepatotoxicity, acute and chronic nephrotoxicity, hypertension, hirsutism and toxic effects on the central nervous system. ${ }^{3}$ Irreversible injury of kidneys has been reported in cardiac transplantation patients on long-term, low-dose CsA therapy. ${ }^{4}$ However, these patients received relatively high-dose cyclosporine in the immediate post-transplant period, but were maintained on about 5 $\mathrm{mg} / \mathrm{kg} / \mathrm{day}$ from 3 to 12 months after transplantation, without further dose reduction in the presence of reduced glomerular filtration rates.

Since CsA therapy in dermatology may be limited by side-effects we tried to improve the risk:benefit ratio with combination therapy CsA-etretinate.

\section{METHODS}

Patients with chronic plaque-type psoriasis resistant to conventional anti-psoriatic therapy were selected. Patients with a concomitant disease were excluded.

Before initiating treatment (baseline) and during CsA therapy, haematologic parameters, serum electrolytes, liver enzymes, serum creatinine and blood pressure were controlled. Clinical evaluation of psoriasis was carried out using the psoriasis-area-and-severity index (PASI)."

All patients received CsA $\left(5.0 \mathrm{mg} / \mathrm{kg} /\right.$ day b.i.d. oral solution Sandimmun ${ }^{(R)} 100$ $\mathrm{mg} / \mathrm{ml}$ ). When the PASI was reduced to less than $25 \%$ from baseline the CsA dose was lowered by $1.0 \mathrm{mg} / \mathrm{kg} /$ day every 4 weeks until an increase of PASI was observed. In the 


\begin{tabular}{|c|c|c|c|c|c|c|c|}
\hline $\begin{array}{l}\text { Pat. } \\
\text { no. }\end{array}$ & ago & $\begin{array}{l}\text { years with } \\
\text { psoriasis }\end{array}$ & $\begin{array}{l}\text { PASI } \\
\text { baseline }\end{array}$ & $\begin{array}{l}\text { PASI } \\
25 \%^{1}\end{array}$ & relupse ${ }^{2}$ & $\begin{array}{l}\text { CsA dose } \\
\text { at PASI }{ }^{3}\end{array}$ & $\begin{array}{l}\text { CsA dose at } \\
\text { relapse }\end{array}$ \\
\hline 1 & 32 & 14 & 22.1 & failure & - & - & 5.0 \\
\hline 2 & 35 & 11 & 38.2 & failure & - & - & 5.0 \\
\hline 3 & 52 & 16 & 48.1 & 6 & 10 & 4.0 & 4.0 \\
\hline 4 & 32 & 4 & 22.1 & 8 & 14 & 4.0 & 3.0 \\
\hline 5 & 45 & 24 & 23.3 & 8 & 16 & 3.0 & 3.0 \\
\hline 1 & \multicolumn{7}{|c|}{$\begin{array}{l}\text { Cyclosporine therapy (weeks) until PASI was } 25 \% \text { or less from baseline value. When after } 8 \\
\text { weeks PASI was still above } 25 \% \text { therapy was considered ineffective (failure). }\end{array}$} \\
\hline 2 & \multicolumn{7}{|c|}{ Cyclosporine therapy in weeks until PASI was abovo 50\% from baseline valus (relapse) } \\
\hline 3 & \multicolumn{7}{|c|}{ Cyclosporine dose (mg/kg/day) at which PASI startod to increase } \\
\hline 4 & \multicolumn{7}{|c|}{ Cyclosporine dose (mg/kg/day) at relapse } \\
\hline
\end{tabular}

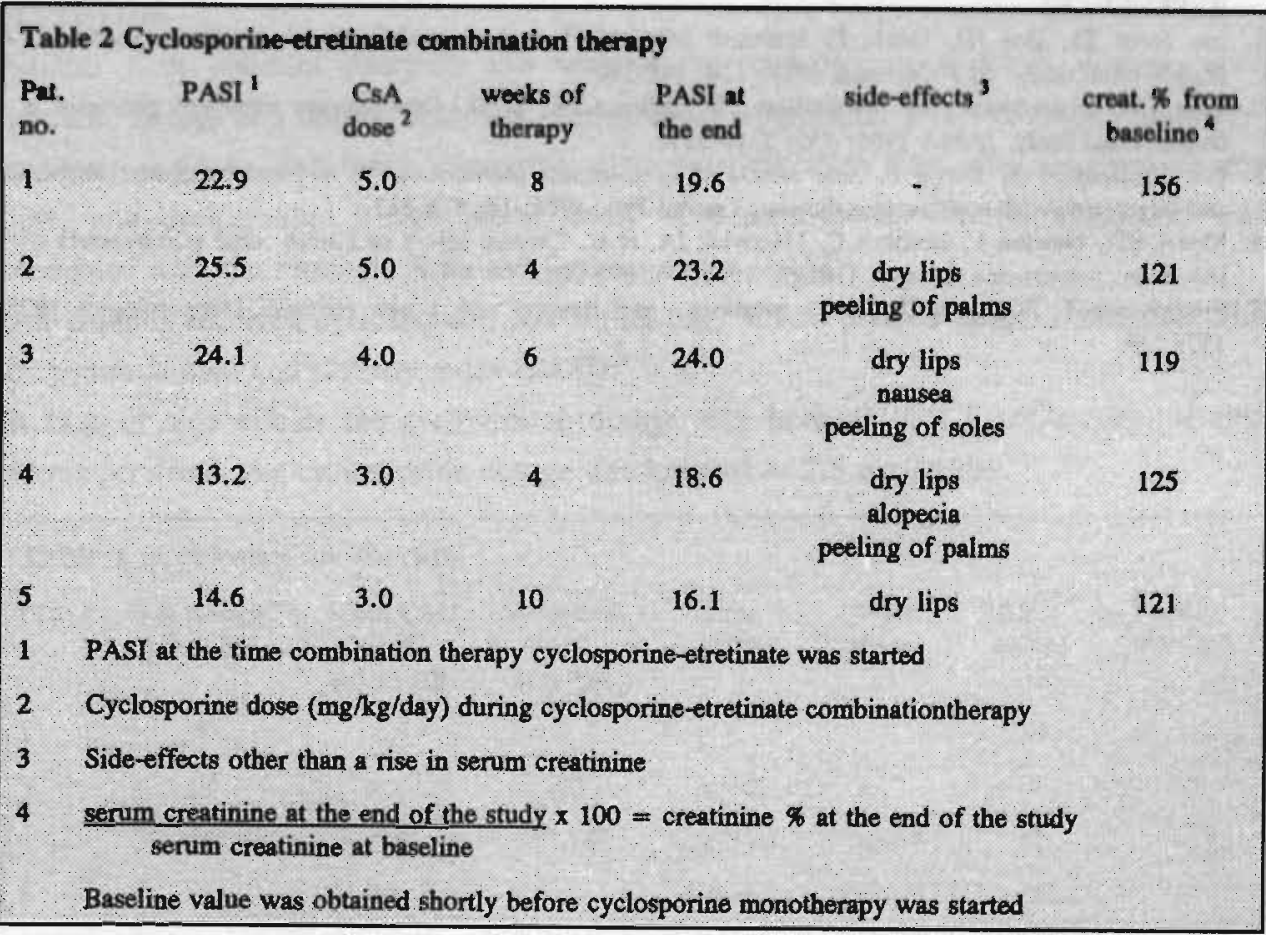

case of relapse (a PASI score of more than $50 \%$ of the baseline value) etretinate $(0.8$ $\mathrm{mg} / \mathrm{kg} /$ day b.i.d.) was added. When, after 8 weeks of CsA therapy, the PASI was still above $25 \%$ from baseline, we considered CsA monotherapy ineffective and etretinate was added. 


\section{RESULTS AND DISCUSSION.}

The results are listed in Tables 1 and 2 . In the patients with severe, therapy resistant, plaque-type psoriasis, CsA therapy was not effective in a dose below $4.0 \mathrm{mg} / \mathrm{kg} /$ day. Long-term treatment with CsA above $4.0 \mathrm{mg} / \mathrm{kg} /$ day may cause irreversible renal damage. ${ }^{4}$ In all patients, serum creatinine increased, which was completely reversible after withdrawal of CsA. However, the therapeutic window for CsA therapy seems to be small.

Except for patient 1 all patients developed side-effects on etretinate therapy. However, an additive therapeutic effect of etretinate in CsA therapy was not observed. Larger studies are required to confirm our observations or to determine subpopulations of psoriasis patients in whom combination therapy with etretinate and CsA can be beneficial.

\section{REFERENCES}

1. van Joost Th, Bos JD, Heule F, Meinardi MMHM. Low-dose cyclosporin A in severe psoriasis. A double-blind atudy. Br J Dermatol 1988: 118; 183-190.

2. Ellis CN, Gorsulowsky DC, Hamilton TD, Billings JK, at al. Cyclosporine improves psoriasis is a double blind study. JAMA 1986: 256; 3110-3116.

3. von Graffenried B, Krupp P. Side effects of cyclosporine (Sandimmun ${ }^{(R)}$ ) in renal transplant recipients and in patients with autoimmune disease. Transpl Proc 1986: 18; 876-883.

4. Myers BD, Newton L, Boshkos C, Macoviak JA, et al. Chronic injury of human renal microvessels with low-dose cyclosporine therapy. Transpl. 1988: 46; 694-703.

5. Fredriksson T, Petterson U. Severe psoriasis - oral therapy with a new retinoid. Dermatologica 1978: $157 ; 238$. 


\subsection{CYCLOSPORINE A AND METHOTREXATE: A DANGEROUS COMBINATION}

M.J. Korstanje, C.J.P. van Broda Vriesman, W.J.B.M. van do Stank J Am Acad Dermatol 1990; 23: 320-321

Recent studies have shown a remarkable beneficial effect of cyclosporine in the treatment of patients with psoriasis. ${ }^{1}$ However, cyclosporine has limited use in practice because of its potential severe side-effects. ${ }^{2}$

Methotrexate has a different mechanism of action in psoriasis. Therefore we triod to improve the risk/benefit ratio by combination therapy with cyclosporine and methotrexate.

\section{METHODS}

Patients with resistant psoriasis and without any concomitant systemic disease were selected. Before and during treatment, hematologic parameters; levels of serum electrolytes, liver enzymes, and serum creatinine; glomerular filtration rate; effective renal plasma flow; and cyclosporine trough blood levels were determined. Clinical evaluation was conducted with the Psoriasis Area and Severity Index (PASI) ${ }^{3}$

All patients received cyclosporine, $5.0 \mathrm{mg} / \mathrm{kg} /$ day, in two divided doses. conducted with the psoriasis area and severity index (PASI). ${ }^{3}$

In case of side effects the cyclosporine dosage was lowered to $3.5 \mathrm{mg} / \mathrm{kg} / \mathrm{day}$. If side effects persisted, the cyclosporine dosage was lowered to $2.5 \mathrm{mg} / \mathrm{kg} /$ day.

\begin{tabular}{|c|c|c|c|c|c|c|c|}
\hline Pat: & $\begin{array}{l}\text { CsA therapy } \\
\text { in weeks }\end{array}$ & $\begin{array}{c}\text { Mean CsA } \\
\text { level } \\
\text { before DR }\end{array}$ & $\begin{array}{c}\text { Mean CsA } \\
\text { level } \\
\text { after DR }\end{array}$ & $\begin{array}{l}\text { Time } \\
\text { of DR }\end{array}$ & $\begin{array}{l}\text { Side- } \\
\text { effects }\end{array}$ & $\begin{array}{c}\text { PASI\%" } \\
\text { before } \\
\text { DR }\end{array}$ & $\begin{array}{l}\text { PASI } \%^{\circ} \\
\text { after DR }\end{array}$ \\
\hline 1 & 8 & 325 & - & - & - & 20 & - \\
\hline 2 & 16 & 220 & 160 & wk 8 & $\mathrm{~K}^{+1}$ & 0 & 50 \\
\hline 3 & 24 & 315 & 215,145 & wk $4+8$ & Creat. 1 & 51 & 8,5 \\
\hline 4 & 12 & 219 & 135 & wk 6 & Creat. 4 & 19 & 50 \\
\hline \multicolumn{8}{|c|}{ CsA = cyclosporine A; DR = dose-reduction(s) } \\
\hline$*$ & \multicolumn{7}{|c|}{$\begin{array}{l}\text { Patient } 1 \text { had generalized pustular psoriasis (von Zumbusch). } \\
\text { All other patients had severe plaque-form psoriasis }\end{array}$} \\
\hline & \multicolumn{7}{|c|}{$\begin{array}{l}\text { Shortly before dose-reduction and before initiating combination-therapy of cyclosporien and } \\
\text { methotrexate }\end{array}$} \\
\hline
\end{tabular}




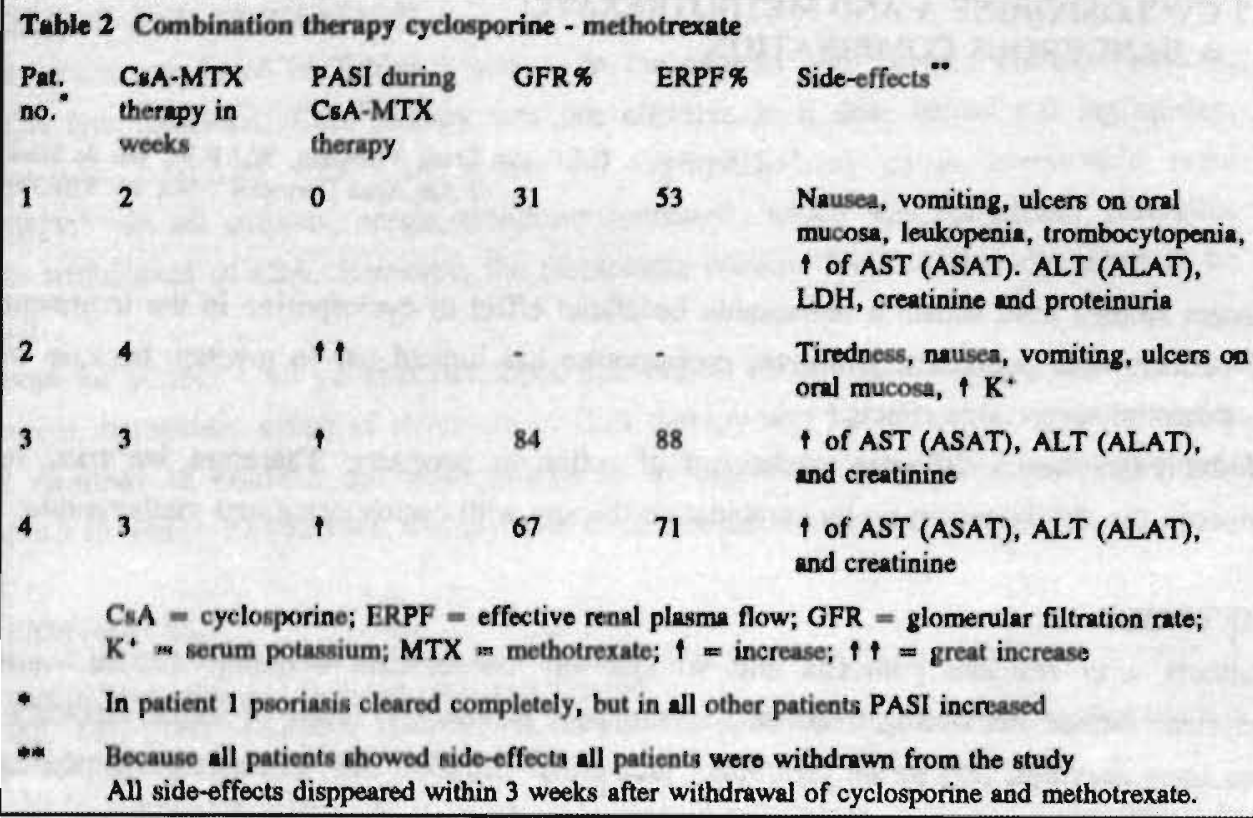

CsA = cyclosporine; ERPF = effective renal plasma flow; GFR = glomerular filtration rate; $\mathrm{K}^{+} \mathrm{m}$ serum potassium; MTX methotrexate; $\uparrow=$ increase; $\uparrow \uparrow=$ great increase

- In patient 1 psoriasis cleared completely, but in all other patients PASI increased

** Becauso all pationis showed side-effects all patients wero withdrawn from the study

All side-effects disppeared within 3 weeks after withdrawal of cyclosporine and methotrexate.

In case of relapse (PASI $>50 \%$ higher than baseline values) or in case of inadequate response to cyclosporine (PASI at week $8>25 \%$ from baseline), methotrexate was added. Methotrexate dose schedule was $2.5 \mathrm{mg}$ at 12 -hour intervals for a total of three doses, repeated at weekly intervals.

\section{RESULTS}

The results are listed in table 1 and 2 . In all patients except for patient 1 , side effects developed with cyclosporine therapy. After dose reduction, psoriasis increased in severety.

\section{DISCUSSION}

Cyclosporine is extensively metabolized in the liver, and the metabolites are excreted mostly by the liver. ${ }^{4}$ Drugs that inhibit hepatic metabolism raise the blood concentration of cyclosporine. ${ }^{4}$ Because hepatotoxicity is a frequent side effect of methotrexate therapy, ${ }^{5}$ it is likely that methotrexate inhibits elimination of cyclosporine. Methotrexate is eliminated mainly by the kidneys. ${ }^{6}$ Most $\left(50 \%\right.$ to $80 \%$ ) is excreted unchanged. ${ }^{6,7}$ Renal clearance of methotrexate and of its metabolite, 7-hydroxymethotrexate, is greater than the glomerular filtration rate, because of tubular secretion. ${ }^{8}$ Acute and chronic nephro- 
toxicity are the most important side effect of cyclosporine. ${ }^{2}$ The glomerular filtration rate is reduced, ${ }^{9}$ and tubular function is impaired. ${ }^{10}$

Cyclosporine and methotrexate therefore decrease one another's elimination. This can increase both methotrexate and cyclosporine blood levels and increase the risk of serious side effects. We strongly recommend that the combination not be used, even in patients with severe unresponsive psoriasis.

\section{REFERENCES}

1. van Joost Th, Bos JD, Heule F, Meinardi MMHM. Low-dose cyclosporin A in severe psoriasis. A double-blind study. Br J Dermatol 1988: 118; 183-190.

2. von Graffenried B, Krupp P. Side effects of cyclosporine (Sandimmun(R)) in renal transplant recipients and in patients with autoimmune disease. Transpl Proc 1986: 18: 876-883.

3. Frederikson T, Petterson V. Severe psoriasis - oral therapy with \& new retinoid. Dermatologica 1978: 157; 238-241.

4. Ferguson RM, Sutherland DER, Simmons RL, Najarian JS. Ketoconazole, cyclosporine motabolism and renal transplantation. Lancet 1982: $2 ; 882$.

5. Kerkhof PCM van de, Mali JWH. Methotrexate maintenance following Ingram therapy in difficult psoriasis. Br J Derma'ol 1982: 106; 623-627.

6. Iven H, Brasch H, Engster J. Pharmacokinetics of methotrexute and 7-hydroxy-methotrexate in rabbits. Cancer Chemother Pharmacol 1985: 15; 115-120.

7. Breithaupt H, Küenzlen E. Pharmacokinetics of methotrexate and 7-hydroxymethotrexate following infusions of high-dose methotrexate. Cancer Treat Rep 1982: 66; 1733-1741.

8. Iven $H, B r a s c h ~ H$. The effects of antibiotics and uricosuric drugs on the renal elimination of methotrexate and 7-hydroxymethotrexate in rabbits. Cancer Chemother Pharmacol 1988: 21; 337-342.

9. Dieperink H, Lessac PP, Kemp E, et al, Nephrotoxicity of cyclosporin A in humans: effects on glomerular filtration and tubular reabsorption rates. Eur J Clin Invest. 1987: 17; 493-496.

10. Versluis DJ, Wenting GJ, Jeekel J, Weimar W. Cyclosporine A related proximal tubular dysfunction: impaired bandling of uric acid. Transpl Proc 1987: XIX; 4029-4030. 


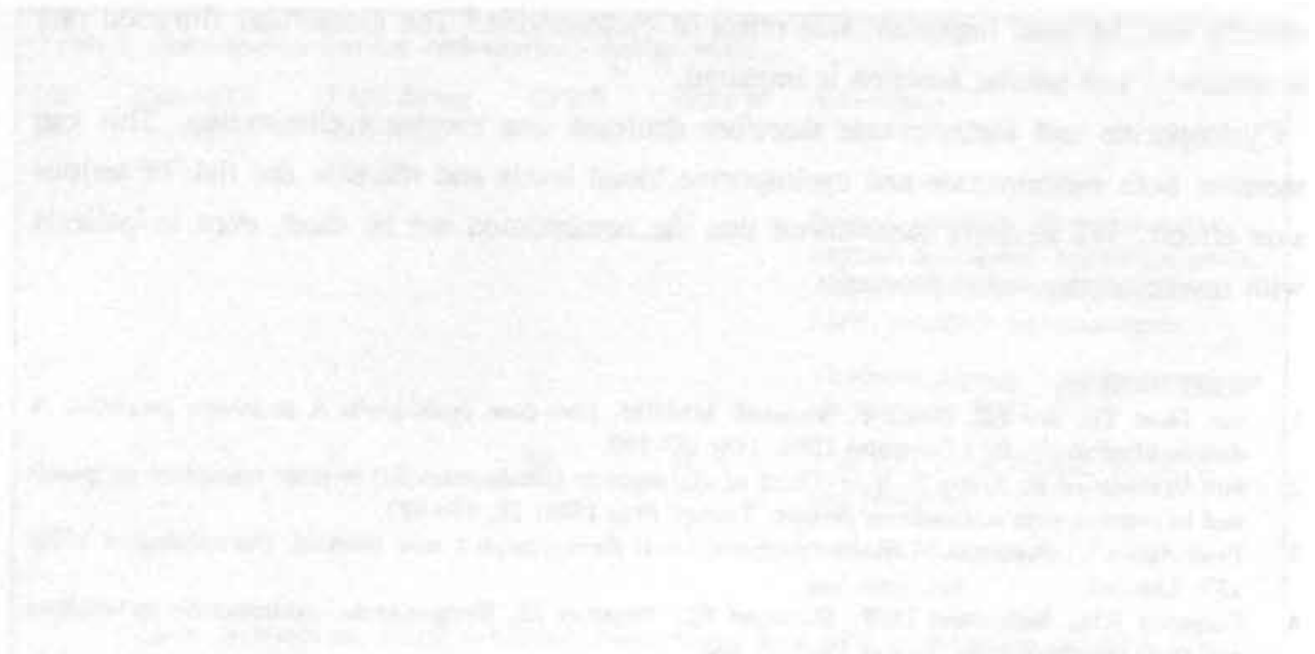




\section{PART IV}

\section{RENAL FUNCTION LOSS AFTER CYCLOSPORINE MAINTENANCE THERAPY FOR PSORIASIS}




\section{7) 720149}

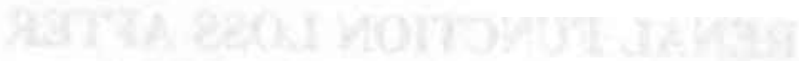

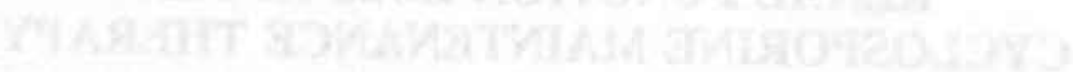

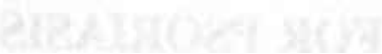




\section{CHAPTER 1.}

\section{INTRODUCTION}

During cyclosporine (CsA) therapy there may be changes to both the tubular and the vascular system of the kidney, and these changes may be either functional or structural in nature. The changes in tubular function are common, not very important clinically, and are reversible. The changes in tubular structure are rare, occur at higher doses, and are also reversible. The changes in vascular function are common, more important clinically, but also revesibel. The changes in vascular structure, with their associated interstitial changes, are infrequent, occur at higher doses but are not reversible once established.

The renal side-effects involving structural changes to the kidney are summarized in Fig.1. The renal side-effects involving functional changes are summarized in Fig.2. The functional changes to the vessels are most noticeable as a vasoconstriction, not confined just to the kidney but also found in the systemic circulation, where they may result in hypertension. In the kidney, vasoconstriction leads to a decrease in kidney perfusion, which results in a decrease in filtration rate. The consequence of this are a rise in serum creatinine and a rise in serum urea levels. Even in the presence of established structural damage to the kidney, it is invariably the functional changes to the vessels in the form of a vasoconstriction that is responsible for renal dysfunction during CsA therapy. Only in cases of severest structural damage is the loss of functioning glomeruli responsible for a decrease in renal function. As it seems clear that the changes in renal vessel structure and function are the most important sideeffects of CsA, it is important to elucidate the underlying mechanisms.

One of the earlier studies concerning mechanisms of vasoconstriction in isolated arteries concluded that CsA itself was a vasoconstrictor. This finding could not be confirmed in subsequent studies in other isolated arteries. ${ }^{1,2}$ In addition, it

\section{Fig.1}

Description of the functional changes to the tubular system and the vascular system occuring frequently during cyclosporine therapy

\section{STRUCTURAL CHANGES}

$\downarrow$

tubulopathy (proximal tubule)

$\downarrow$

isometric vacuoles giant mitochondria single cell necrosis microcalcifications

$\downarrow$ striped interst. fibrosis mostly reversible glomenular sclerokis localised ischaemia tubular atrophy.

vasculopathy
(afferent arteriole)

$\downarrow$

endothelial injury muscle wall damage arteriolar occlusion vessel obliteration

$+$

largely irreversible 
was not possible to find any binding of CsA to those receptors that cause vasoconstriction in the kidney, such as alpha-adrenergic or adenosin receptors. Also, there was almost no increase in resting intracellular $\mathrm{Ca}$ levels in contractile cells, with which to initiate contraction. ${ }^{3.5}$ Therefore, the theory that CsA exerts a direct constrictory action has to be discarded.

The next mechanism that has been postulated to explain vasoconstriction is a CsA-induced increase in thromboxane and decrease in prostacyclin production. This theory was based upon the observation that thromboxane excretion is raised and prostacyclin excretion decreased in the urine of CsA-treated rats.

Another mechanism possibly involved in the generation of vasoconstriction is the action of CsA to enhance the rise in intracellular $\mathrm{Ca}$ seen upon stimulation with a vasoconstrictor substance. In smooth muscle cells, the calcium peak generated in response to stimulation with a vasoconstrictor substance. In smooth muscle cells, the calcium peak generated in response to stimulation with angiotensin or vasopressin is much enhanced in the presence of CsA., This finding is also seen in glomerular mesangial cells grown in culture. ${ }^{5,6}$ These contractile cells may, therefore, be hyperactive in the presence of CsA

Fig. 2

Description of the structural changes to the tubular system and the vascular system occuring rarely duriag cyclosporine treatment.

\section{FUNCTIONAL CHANGES}

$\downarrow$

tubular dysfunction

$+$

- Mg reabsorption

$+\mathrm{K}^{+}$and $\mathrm{K}^{+}$secretion

$\downarrow$ uric acid excretion

$\downarrow$

$+\mathrm{Mg}^{2 *},+\mathrm{K}^{+}$,

$+\mathrm{HCO}_{3}$; and

1 uric acid in serum

fully neversible $\downarrow$

vascular dysfunction

$\downarrow$

- vasoconstriction

+ kidney perfusion

- filtration rate

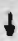

i serum creatinine 1 serum ura

fully reverible and contract more to any level of stimulation caused by any vasoconstrictor.

A further mechanism that may enhance vasoconstriction is the plasma volume depletion seen in CsA-treated animals. When injected with radiolabeled albumin, it is apparent that the disappearance of albumin from the circulation is much higher in the CsA-treated animals than in the control animals. Hence, it seems as if the endothelium has become leaky to albumin causing plasma volume to decrease. Vasoconstriction may then partly be explained by a physiologically appropriate response to compensate for volume depletion. 
A final mechanism causing vasoconstriction may be an activation of renin within the walls of renal arteries. The constrictor response of porcine renal arteries to angiotensin II does not differ in the presence or absence of CsA. However, the constrictor response to angiotensinogen, the substrate of renin, is much greater in the presence than in the absence of CsA. Since the response to angiotensin I or II is not altered, the enhanced response to renin substrate suggests renin activation and increased production of angioten$\sin$ I and II. This mechanism of local renin activation and enhanced angiotensin production within the vessel wall could explain why vasoconstriction predominates in the reninrich renal vessels.

\section{REFERENCES}

1. Lamb FS, Webb RC. Cyclosporine augments reactivity of isolated blood vessels. Lifo Sci 1987; 40: 2571-2578

2. Müller-Schweinitzer E, Mason J. Effect of Sandimmune on isotated blood vessels. Kidney Int 19k9; 35: 331

3. Pfeilschifter J, Rũegg UT. Cyclosporin A augments angiotensin Il-stimulated rise in intracellular free calcium in vascular smooth muscle cells. Biochem J 1987; 248: 883-887.

4. Meyer-Lehnert H, Schrier RW. Potential mechanism of cyclosporin A-induced vascular smooth muscle contraction. Hypertiension 1989; 13: 352-360

5. Meyer-Lehnert $\mathrm{H}$, Sehrier RW. Cyclosporine $\mathrm{A}$ enhances vasopressin-induced $\mathrm{Ca}^{24}$ mobilization and contraction in mesangial cells. Kidney Int 1988; 34: 89-97.

6. Kremer SG, Margolis B, Goldberg H, Skorecki KL. Effects of cyclosporie A (CyA) on calcium signalling and prostaglandin production in glomerular mesangial cells (MC). Kidney Int 1988: 33; 361 .

7. Davarajan P, Kaskel FJ, Arbeit LA, Moore LC. Cyclosporine nephrotoxicity: Blood volume, sodium conservation and renal bemodynamics. Am.J.Physiol 1989; 256 (Renal Fluid Electr. Physiol. 25): F71-F78.

8. Mueller-Schweinitzer E, Mason J, Olea Baza I. Action of Sandimmune on porcine renal arteries. Kidney Int 1990; 37: 598 


\title{
CHAPTER 2
}

\section{ASSESSMENT OF RENAL FUNCTION AND RENAL FUNCTION CHANGES DURING CYCLOSPORINE TREATMENT}

\begin{abstract}
Serum creatinine (Screat), the Cockroft formula (Cock) and creatinine clearance rate are used in daily practice to assess renal function. The reliability of these assessment techniques remains questionable, however. We measured Glomerular Filtration Rate (GFR, 1251-iothalamate), Screat and Cock in 63 subjects with a normal renal function before and after cyclosporine administration ( $\mathrm{CsA}$ (126 paired observations, Group I) and in 50 renal transplant recipients (a total of 158 observations, up to 4 in each subject, Group II). All results were compared in the whole group with all observations combined (284) and in the separate groups (Wilcoxon and Spearman). Furthermore, changes in renal function were assessed by comparing the known pairs (Group I: 63, Group II:108, analysis of \%delta change).

When combining all results, correlations were well: GFR vs Screat: $r=-0.84$, GFR versus Cock: $r=0.93$. This was different with separate analysis: in Group $I: r=-0.22$ and $r=0.59$, resp; in Group II: $r=-0.73$ and $r=0.86$. With decreasing GFR, the difference between GFR and Cock increased. In Group I, GFR and Cockroft did not differ; in Group II, the difference amounted to $18.7 \%(-20.7$ to $135.7 \%)(p<0.01)$. In Group I, changes in GFR were poorly predicted by changes in Screat and Cock: \%delta GFR vs \%delta Screat: $r=-0.30$, vs \%delta Cock: $r=0.25$. It improved in Group II: $r=-0.67$ and $r=0.67$, respectively.

We therefore conclude that Screat is a poor indicator of renal function in normals, and neither changes in Screat or Cock are able to accurately reflect the individual changes in GFR after CsA-administration. Despite better correlations in renal transplant recipients, Cock overrates renal function as assessed by GFR markedly under such circumstances. Changes in GFR are not adequately reflected by changes in Screat in such patients despite an apparently acceptable correlation.
\end{abstract}




\section{ENTRODUCTION}

Since its introduction, cyclosporine A ( $\mathrm{CsA})$ is accepted as an important treatment modality in transplantation medicine..$^{1.3}$ Despite its widespread use, it also has significant side effects. ${ }^{4-11}$ However, since advantages often outweigh disavantages with CsA after transplantation, side effects are accepted as well. One of its main side effects is a deterioration of renal function. ${ }^{10,11}$ To assess the influence on renal function of CsA, changes in creatinine and creatinine clearance rate are used in clinical practice.

The last years do see the introduction of $\operatorname{CsA}$ as a treatment for other disease modalities as well. ${ }^{12-16}$ Its use has also been advocated in diseases as diverse as insulin-dependent diabetes mellitus, inflammatory bowel diseases, uveitis, rheumatoid arthritis and multiple sclerosis. Several studies have shown a beneficial effect of CsA in patients with psoriasis or atopic dermatitis. ${ }^{17-23}$ Such patients often have a normal renal function before the start of therapy, and CsA subsequently causes a loss of renal function, quite often leading to an adjustment or even withdrawal of CsA. After withdrawal of CsA, renal function as assessed by measurement of glomerular filtration rate (GFR), does not always return to its pretreatment values. ${ }^{22}$ Remarkably, when only looking at serum creatinine (Screat) levels, this loss in GFR is not noted.

Cockroft and Gault advocated the use of a specific formula (implicating Screat, age, weight and sex) to calculate creatine clearance rate in order to prevent the necessity of collecting 24-hour urine samples. ${ }^{23}$ They considered the 24-hour sampling cumbersome and often unreliable. Some consider the renal function assessment by the Cockroft approach as superior to the use of Screat.

In order to get an impression of the reliability as a tool to assess renal function and renal function changes of various methods, we performed a retrospective study of psoriasis patients, who received CsA for variable periods and dosages as treatment for severe plaque form psoriasis. Furthermore, renal transplant recipients, receiving CsA posttransplant for up to a year, were studied as well. The results of the measurements of GFR ${ }^{(25}$ I-iothalamate) and Screat, and Cockroft calculation were compared, both as separate values and as tools to assess the changes in renal function during CsA therapy.

\section{METHODS}

A total of 113 subjects were analyzed for this study. Sixty-three subjects participated in projects, studying the effects of cyclosporine in psoriasis patients. ${ }^{18}$ All these subjects had a normal renal function at inclusion in any of the studies, as assessed by serum creatinine. Both at baseline and after the administration of varying doses of cyclosporine during 
varying study periods, renal function studies were performed. Cyclosporine doses never exceeded $5 \mathrm{mg} / \mathrm{kg}$ in these patients.

Fifty renal transplant recipients, participating in another study were analyzed as well. ${ }^{24}$ All patients received cyclosporine after their renal transplant and glornerular filtration rates were measured 1 month, 3 months 6 months and 12 months posttransplant.

Serum creatinine was measured concomittantly.

Renal function studies were performed with determination of the ${ }^{125} \mathrm{I}$-iothalamate clearance for Glomerular Filtration Rate (GFR), using the formula U*V/P. The coefficient of variation of day-to-day determination of ${ }^{125}$-iothalamate clearance amounts to $2.2 \%$. $^{24}$ Results are expressed as $\mathrm{ml} / \mathrm{min}$ and not corrected for body surface area.

Creatinine clearance rate was calculated using the Cockroft formula: ${ }^{23}$

Cockroft $(\mathrm{ml} / \mathrm{min})=1.23 *[140-\text { Age(years) }]^{*}$ weight $(\mathrm{kg})$ (to be muttiplied by 0,85 for women) Screat $(\mu \mathrm{mol} / \mathrm{l})$

This formula was the result of efforts to calculate the renal function as accurate as possible using the Screat. Empirical evidence showed that the best result was obtained with the $1 /$ Screat corrected for weight and age with a correction factor of 0.85 for women. (Women have a smaller lean body mass in relation to their weight compared with men).

\section{STATISTICAL ANALYSIS}

All data are given as medians and ranges. For comparison of paired data a Wilcoxon signed rank test was used. Data were correlated using the Spearman test. A p-value of less than 0.05 was considered statistically significant.

The difference between two observations with Screat, Cock, and GFR is called delta Screat, delta Cock and delta GFR respectively. The \%delta is the difference between the two observations expressed as a percentage of the first observation.

The difference between Cock versus Screat, GFR versus Screat, GFR versus Cock is called the difference Cock versus Screat, difference GFR versus Screat, and difference GFR versus Cock respectively. The \%difference is the difference between the two measurements expressed as a percentage from the first measurement.

The change in the difference between two observations (eg. Cock versus Screat) is called the delta difference and can be expressed as an absolute delta difference in $\mathrm{ml} / \mathrm{min}$ or as a percentage of the first observation (\%delta difference). 


\section{RESULTS}

The group characteristics are shown in Table 1. As can be seen, the sixty-three subjects with a normal renal function underwent renal function studies twice, allowing the analysis of changes in renal function in 63 pairs. In the renal transplant recipients, 50 subjects were analysed one month post-transplant, 48 three months post-transplant, 43 six months and 17 twelve months post-transplant, allowing the analysis of changes in renal function in 108 paired observations (48 one versus three months, 43 three versus six months, and 17 six versus twelve months).

When comparing the combined results of all renal function studies $(126+158=284$ observations), Cockroft calculation sho-

\begin{tabular}{|c|c|c|c|}
\hline \multirow{2}{*}{\multicolumn{2}{|c|}{ Table 1}} & \multicolumn{2}{|c|}{$\begin{array}{l}\text { Group characteristics; } \\
\text { medians and ranges }\end{array}$} \\
\hline & & $\begin{array}{l}\text { Normal renal } \\
\text { function }\end{array}$ & $\begin{array}{l}\text { Renil } \\
\text { transplant } \\
\text { recipients }\end{array}$ \\
\hline a & & 63 & 50 \\
\hline & line OFR* & $113(64-177)$ & $40(14-82)$ \\
\hline & ations & $126(a)$ & $158(\mathrm{~b})$ \\
\hline & female & $41 / 22$ & $28 / 22$ \\
\hline & (years) & $37(20-67)$ & $44(17-66)$ \\
\hline & (kg) & $75(50-138)$ & $66,5(46-91)$ \\
\hline & \multicolumn{3}{|c|}{ GFR uncorrected for Body Surface Area } \\
\hline & \multicolumn{3}{|c|}{63 at baseline; 63 after cyclosporino treatment } \\
\hline & \multicolumn{3}{|c|}{$\begin{array}{l}50 \text { one month post-transplantation; } \\
48 \text { three months post-transplantation; } \\
43 \text { six months post-transplantation } \\
17 \text { twelve months post-transplantation }\end{array}$} \\
\hline
\end{tabular}

wed a substantially higher value compared to the GFR measurement: (median and ranges) \%delta difference: $10.6 \%$ (-32.9 to $135.7 \%)$, absolute delta difference: $6.4 \mathrm{ml} / \mathrm{min}(-42.2$ to $48.3 \mathrm{ml} / \mathrm{min}$ ) (Table 2A). Correlation was remarkably well, $\mathrm{r}=0.9261$ (Table 2B).

When analyzing the separate groups, the correlation between the GFR and the Cockroft formula was less pronounced: $n=126, r=0.59$. In subjects with a normal renal function, GFR and Cockroft did not differ (Table 3A-1), as opposed to the results in renal transplant recipients: the GFR and the Cockroft formula showed a \%difference of $18.7 \%$ $(-20.7$ to $135.7 \%$ ) (Table 4B-1). Correlation between GFR and Cockroft in this group was $\mathrm{n}=158, \mathrm{r}=0.86$. Therefore, the significant difference between GFR and Cockroft in the whole group had to be attributed to the renal transplant recipients only. When comparing GFR with the \%difference between Cockroft and GFR it seems that with decreasing GFR the \%difference increased $(n=284, r=-0.56 ; n=158, r=-0.43$, respectively).

There was a good correlation between GFR and Screat when analyzing all observations $(n=284, r=-0.84$, Table 2B). This was different when only correlating the results in subjects with normal renal function: $n=126, r=-0.22$ (Table $3 B$ ). In renal transplant 


Table 2
Combined andysis of all reaults
(a $=284 ; 126+150)$

recipients, with a much larger variation in renal function, correlation between GFR and Screat amounted to $n=158, r=-0.73$ (See table 4B-2). In subjects with a normal renal function, \%delta GFR and \%delta Cockroft did not correlate well: $n=63, r=0.25$, nor

\section{Table 3}

GFR, serum creatinine and Cockroft at baseline and after cyclosporine (CSA) administration in 63 psoriasis patients.

A-1: Separate analysis of results.

$$
\text { Baseline: }
$$

CsA

GFR

(ml/min)

$113(64-177)$

95 (56-168)

$(p<0.01)$

\%dalt $-11.6 \%(-40.2$ to $17.9 \%)$

Sereat

$83(54-104)$

$91(59-149)$

( $\mathrm{mmol} / \mathrm{I})$

$(p<0.01)$

\%del t $10.0 \%(-14.4 \% 93.5 \%)$

$$
\text { Cockroft } \quad 109(68-154) \quad 99(61-168)
$$

$(\mathrm{ml} / \mathrm{min}) \quad(\mathrm{P}<\mathrm{C.01})$

Tdelt $-9.0 \%(-48.9$ to $18.5 \%)$

weight (k8) 75 (50-138) 75 (72-135)

SDelta is the difference between baseline and the value after cyclosporine administration expressed as a percentage from baseline value

\section{A-2: Correlasions (Spearman)}

\%delta GFR vs \%delta Screat $\quad r=-0.30$

\%delts GFR vs \%delta Cockroft $r=0.25$

कodelta Sereat vs \%delta Cockroft $r=-0.94$

$B$ :

Comparison/correlation of 126 observations

GFR vo Screat $\quad r=-0.23$

GFR vs Cockroft $\quad r=0.59$

Cockroft vs Screat $\quad r=-0.23$

did \%delta GFR versus \%delta Screat: $n=63, r=-0.30$. Incidentally, the \%delta Cockroft and \%delta Screat correlated well: $n=63, r=-0.94$ (Table 3A-2).

In renal transplant recipients, GFR and Cockroft increased during the follow-up period (Table $4 \mathrm{~A})$. This also held true when analyzing all paired observations $(\mathrm{n}=108$, Table $4 \mathrm{C}-1)$. Screat did not show changes during the one year study period, nor in the paired analysis. However, despite this the \%delta GFR correlated well with the \%delta Screat $(n=108, r=-0.67$ ). 


\begin{tabular}{|c|c|c|c|c|c|}
\hline \multicolumn{6}{|c|}{$\begin{array}{l}\text { GFR, serum creatinine (Screat), Cockroft formula (Cock), and weight in renal transplant } \\
\text { recipients } 1 \text { month, } 3 \text { months, } 6 \text { months, and } 12 \text { months posttransplantation }\end{array}$} \\
\hline \multicolumn{6}{|c|}{ A: Separate analysis of results (medians and ranges) } \\
\hline & : & GFR & Screat & Cockroft & Weight \\
\hline 1 month & 50 & $\begin{array}{c}40 \\
(14-82)\end{array}$ & $\begin{array}{c}157 \\
(77-406)\end{array}$ & $\begin{array}{c}46^{\circ} \\
(21-86)\end{array}$ & $\begin{array}{c}66.5 \\
(46.4-91.0)\end{array}$ \\
\hline 3 months & 48 & $\begin{array}{c}42^{* *} \\
(19-84)\end{array}$ & $\begin{array}{c}158 \\
(90-280)\end{array}$ & $\begin{array}{l}52^{\circ} \cdots \\
(25-95)\end{array}$ & $\begin{array}{c}69.9^{* *} \\
(50.7-95.0)\end{array}$ \\
\hline 6 months & 43 & $\begin{array}{c}46^{* 04} \\
(14-85)\end{array}$ & $\begin{array}{c}155 \\
(77-271)\end{array}$ & $\begin{array}{c}49^{\circ} * \cdots \\
(30-102)\end{array}$ & $\begin{array}{l}71.2^{n i j+0} \\
(51.4-93.5)\end{array}$ \\
\hline 12 months & 17 & $\begin{array}{c}56^{\circ} \\
(26-111)\end{array}$ & $\begin{array}{c}142 \\
(87-232)\end{array}$ & $\begin{array}{c}54^{*} \\
(26-121)\end{array}$ & $\begin{array}{c}70.5^{m * *} \\
(55.9-96.0)\end{array}$ \\
\hline
\end{tabular}

The \%delta GFR also showed a good correlation with the \%delta Cockroft: $n=108$, $r=0.67$. Again, the \%delta Cockroft and \%delta Screat showed the best correlation: $\mathrm{n}=108, \mathrm{r}=-0.95$.

\section{DISCUSSION}

Much discussion is going on regarding the best method to assess renal function and renal function changes in subjects with an initially normal renal function treated with relatively low doses of cyclosporine. Menter and Barker recently suggested that Screat is

48-1: Combined analywis of 185 rewultw GFR

(ml/min)

Cockroft

(ml/min)

sCreat

( $\mu \mathrm{mol} / \mathrm{l})$

43 (14-111)

$49(21-121)(p<0.01)$

$156(77-406)$

\%difference

GFR vs Cock

$18.7 \%(-20.7$ to $135.7 \%)$

$(\mathrm{p}<0.01)$

4B-2: Correlations (Spearman)

GFR versus Screat

$r=-0.73$

GFR versus Cockroft

$r=0.86$

Cockroft versus Screat

$r=-0.74$

a poor indicator of renal function in such patients, this in contrast to GFR measurements. ${ }^{25}$ Others either do show a better correlation between both renal function assessment techniques ${ }^{26}$ or do want to believe us in such a better correlation. ${ }^{27}$

Our study in subjects with initially normal renal function does show a poor correlation between GFR as assessed by ${ }^{125}$ I-iothalamate and Screat (and,incidentally, 1/Screat as well). Furthermore, although Screat rises with CsA-therapy in about the same magnitude as the decrease in GFR (Table 3A-1), the individual changes in GFR are not properly reflected by the individual changes in Screat, as shown in the poor correlation between 


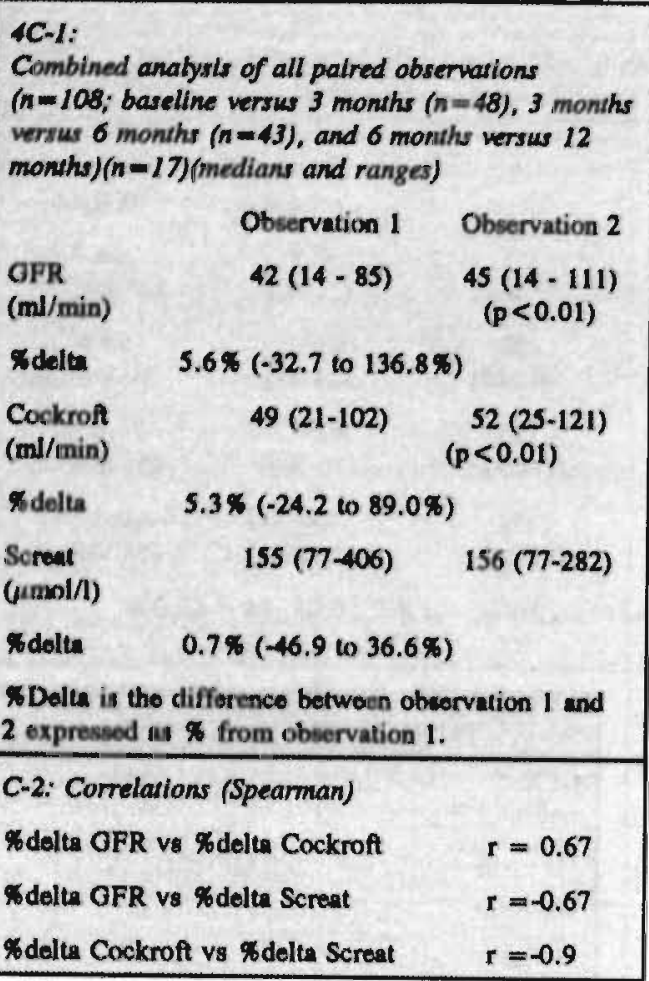

the \%delta GFR and the \%delta Screat $(r=-0.30)$. Moreover, Screat does not reflect properly the sustained loss in GFR $^{n}$ which may remain after CsA treatment in psoriasis patients. This has also been confirmed in multiple sclerosis patients. ${ }^{14}$ Again, others do want to believe us otherwise. ${ }^{28}$

Use of the Cockroft formula in subjects with an initially normal renal function yields a better correlation between the absolute results as compared to GFRmeasurements (Table 3A-1). However, again the \%delta Cock is only poorly correlated to the \%delta GFR, thus also rendering it a less valuable tool to assess renal function changes in such patients.

Renal function, as assessed by ${ }^{125} \mathrm{I}-$ iothalamate, definitely improves during the first year after renal transplantation in our study population. This vast improvement from a median of 40 to a median of 56 $\mathrm{ml} / \mathrm{min}$ is not reflected in changes in Screat values (Table 4A). The good correlation between \%delta GFR and \%delta Screat therefore does not appear to be as reassuring as can be possible.

Cockroft overestimates GFR, and rises during the year as well. However, since Screat does not change, one wonders whether this rise in Cockroft is not due to the rise in weight in our study population. Since an increase in weight in renal transplant recipients is more connected to an increase in fat and extracellular volume than to an increase in muscle mass, such a weight increase (being a 'zero-creatinine' increase) would artificially raise renal function.

Despite this, correlations between GFR on one hand and Cockroft and Screat on the other hand are well. Such apparently good correlations can be due to the same effect as shown when analyzing all results together: when including enough results at both sides of the possible renal function spectre (from very low to normal), correlation analysis will more often show a good result (renal function in our renal transplant recipients varied from 14 
to $111 \mathrm{ml} / \mathrm{min}$ ). Still, this cannot be an explanation for the reasonable correlation between \%delta GFR, and \%delta Cockroft and \%delta Screat (Table 4C-2).

When comparing GFR and Cockroft in renal transplant recipients, the \%difference increases with decreasing renal function. Our study cannot explain this difference. With decreasing renal function, tubular secretion of creatinine will increase. In the Cockroft formula, a decrease in Screat will lead to a higher calculated renal function. Further studies will be necessary to either confirm or refute this assumption.

We therefore conclude that Screat is a poor indicator of renal function in subjects with an initially normal renal function, and neither changes in Screat or Cock are able to accurately reflect the individual changes in GFR after CsA-administration. Despite better correlations in renal transplant recipients, Cock overrates renal function as assessed by GFR markedly under such circumstances. Changes in GFR are not adequately reflected by changes in Screat in such patients despite an apparently acceptable correlation.

\section{ACKNOWLEDGMENTS}

The data, analyzed for this manuscript, were kindly made available by dr.H.C.G.Bilo, and dr.J.J.Homan van der Heide, Dept.of Medicine, Ziekenhuis de Weezenlanden, Zwolle and Dept. of Medicine, University Hospital Groningen respectively.

\section{REFERENCES}

1. Calne RY, White DJG, Thiru S, Evans DB, et al. Cyclosporin A in patients receiving renal allografts from cadaveric donors. Lancet 1978; ii: 1323-1327.

2. European Multicenter Trial Group. Cyclosporine in cadaveric renal transplantation: one year follow-up of a multi-center trial. Lancet 1983; ii: $986-989$.

3. Canadian Multicenter Transplant Study Group. A randomized clinical trial of cyclosporine in cadaveric renal transplantation. N Engl J Med. 1983; 309: 809-815.

4. Editorial. Ciclosporin Hypertension. Lancet 1988; ii: 1234

5. Vathsala A, Weinberg RB, Schoenberg L, et al. Lipid abnormalities in cyclosporin-prednisone-treated renal transplant recipients. Transplantation 1989; 48: 37-43

6. Ballantyne CM, Podet EJ, Patsch WP, et al. Effects of cyclosporin therapy on plasma lipoprotein levels. JAMA 262: 53-56

7. Bending JJ, Ogg CS, Viberti C. Diabetogenic effect of cyclosporin. Br.Med.J. 1987; 294: 401-402

8. Vanrenthergem $Y$, Roels $L$, Lerut $T$, et al. Thromboembolic complications and haemostatic changes in cyclosporin-treated cadaveric kidney allograft recipients. Lancet 1985 ; i: 999-1002

9. Cohen H, Neild GH, Patel R, Mackie IJ, Machin SJ. Evidence for chronic platelet hyperaggregability and in vivo activation in cyclosporin-treated renal allograft recipients. Thrombosis Research 1988; 49: 91-101

10. Meyers BD, Ross J, Newton L, Luetscher J, Perlroth M. Cyclosporin associated chronic nephropathy. N Engl J Med 1986; $311: 699-705$.

11. Dieperink H, Leyssac PP, Kemp E, Starklint H, et al. Nephrotoxicity of cyclosporin A in humans: effects on glomerular filtration and tubular reabsorption rates. Eur J Clin Invest 1987; 17: 493-496.

12. The Canadian-European Randomized Control Trial Group Cyclosporin-induced remission of IDDM after early intervention: association of $1 \mathrm{yr}$ of cyclosporin treatment with enhanced insulin secretion.

Diabetes 1988; 27: 1574-1582 
13. Berg KJ, Forre $O$, Djoseland $O$, Mikkelsen $M$, et al. Reaal side effects of high and low cyclosporin $A$ doses in patients with rheumatoid arthritis. Clin Nephrol 1989; 31: 232-238

14. Mispelblom Meyer JO, Donker AM, Koetsier JC. Renal function three months after discontinuation of cyclosporin in patients with multiple sclerosis. Kidney Int 1988; $40: 560 \mathrm{~A}$

15. Palestine AG, Austin HA, Balow JE, et al. Renal histopathologic alterations in patients treated with cyclosporine for uveitis. New Engl J Med 1986; 314: 1293-1298

16. Hannadouche T, Natow S, Garev L, Marquez LP, et al. Renal haemodynamic effects of short term cyclosporin A administration in patients with insulin-dependent diabetes mellitus. Nephrol. Dial. Transplant. 1990; 5: 168-173.

17. Ellis CN, Gursulowsky DC, Hamilton DA. Cyclosporin improves psoriasis in a double-blind study. JAMA 1986; 256: 3110-3116

18. Stoof TJ, Korstanje MJ, Bilo HJG, Starink ThM, et al. Does fish oil protect renal function in cyclosporin treated psoriasis patients? J Int Med 1989; 226; 437-441

19. van Joost Th, Bos JD, Heule F, Meinardi MMHM. Low dose cyclosporin A in severe psoriasis. A double blind study. Br J Dermatol 1988: 118: 183-190

20. Ellis CN, Fradin MS, Messann JM, Brown MD, et al. Cyclosporine for pleque-type psoriasis. Results of a multi dose, double blind trial. N Eng J Med 1991; 324: 277-284.

21. Taylor RS, Cooper KD, Headington JT, Ho VC, et al. Cyclosporine therapy for severe atopic dermatilis. J Am Acad Dermatol 1989; 21: 580-583.

22. Korstanje MJ, Bilo HJG, Stoof TJ. Sustained renal function loss in psoriasis patients after withdrawal of low-dose cyclosporin therapy. Br J Dermatol: 1992; 127: 501-504.

23. Cockroft DW, Gnult MH. Prediction of creatinine clearance from serum creatinine. Nephron 1976; 16: $31-41$

24. Donker AJM, van der Hem GK, Sluiter WJ, Beekhuis W. A radio-isotope method for simultaneous determination of the glomerular filtration rate and the effective renal plasma flow. Neth J Med 1977; 20: $97-103$

25. Menter A, Barker JNWN. Psoriasis in practice. Lancet 1991; 338: 231

26. Mason J, Moore L. Indirect assessment of renal dysfunction in patients taking cyclosporin A for autoimmune diseases. Br J Dermatol 1990; 122 (Suppl.36): 79-84

27. Feutren G, Mason J. Serum creatinine or glomerular filtrattion rate for monitoring cyclosporin therapy. Lancet 1991; 338: 1017 (Letter)

28. Feutren G, Abeywickrama K, Friend D, von Graffenried B. Renal function and blood pressure in psoriatic patients treated with cyclosporin A. Br J Dermatol 1990; 122 (Suppl.36): 57-69 


\section{CHAPTER 3}

\section{SUSTAINED RENAL FUNCTION LOSS IN PSORIASIS PATIENTS AFTER WITHDRAWAL OF LOW-DOSE CYCLOSPORINE, THERAPY}

M.J.Korstanje, H.J.G.Bilo, T.J.Stoof Br J Dermatol 1992; 127: 501-504

\section{ABSTRACT}

Eight patients with psoriasis received low dose cyclosporine (CsA) treatment for an average period of 12 months (range 4-16 months). Among patients there was great variability in minimal effective CsA dose. In $50 \%$ of the patients long-term treatment was limited by dose reductions necessitated by side-effects.

A considerable impairment of renal function during csA therapy was found. Glomerular filtration rate (GFR) and effective renal plasma flow (ERPF) were measured with ${ }^{125} \mathrm{I}$ iothalamate and ${ }^{13 i} \mathrm{I}$-hippuran, respectively. Both at the end of the active treatment period (GFR-CsA and ERPF-CsA) and 4 months after withdrawal of CsA (GFR-4mo and ERPF$4 \mathrm{mo}$ ) there was sustained renal impairment (GFR-BL $=97$ (range 64-117), GFR-CsA reduction $17.8 \%(2.2-31.9 \%)$ [p<0.02], GFR-4mo reduction $=9.8 \%(5.5-21.5 \%)$ $\mathrm{ml} / \mathrm{min} / 1.73 \mathrm{~m}^{2}$ ( $\mathrm{p}<0.05$ vs BL); ERPF-BL $=401$ (232-607), ERPF-CsA reduction $=10.1 \%(7.4-27.3 \%)[p<0.05]$, and ERPF-4mo reduction $=13.5 \%(3.0-32.9 \%)$ $\mathrm{ml} / \mathrm{min} / 1.73 \mathrm{~m}^{2}[\mathrm{p}<0.02]$. Further studies of the effects on renal function during, and after, long-term therapy for psoriasis with low-dose CsA are warranted. 


\section{INTRODUCTION}

Several studies have shown a beneficial effect of cyclosporine A (CsA) in patients with psoriasis. ${ }^{1.2}$ Subsequent withdrawal of the drug, however, often leads to reappearance of the skin lesions to the same extend as before treatment. Therefore, treatment with CsA has to be continued according to the natural course of the disease. Withdrawal of CsA or dose reductions are often necessary because of the side-effects. ${ }^{3,4}$ It has been suggested that side-effects are completely reversible after withdrawal of CsA, but there are reports of chronic irreversible renal injury with a CsA dose as low as $4.6 \mathrm{mg} / \mathrm{kg} /$ day. ${ }^{5.6}$ Morphological renal changes were also found in a patient treated for psoriasis with a dose of 2.5 $\mathrm{mg} / \mathrm{kg} /$ day. ${ }^{?}$

We carried out a pilot-study with low-dose CsA for psoriasis, in order to determine whether renal impairment is completely reversible after withdrawal of CsA.

\section{METHODS}

Eight patients with chronic plaque psoriasis, (median age 39 [range 25-60] years; median duration of disease 17 [range 4-43] years)were studied. The median psoriasis area and severity index (PASI) ${ }^{8}$ score was 19.8 [range 18.0-23.1]. Patients with concomitant disease, proteinuria, or haematological or biochemical measurements outside the normal range, were excluded.

All patients received $5.0 \mathrm{mg} / \mathrm{kg} /$ day CsA given in two doses. After week 12 the CsA dose was reduced $0.35 \mathrm{mg} / \mathrm{kg} /$ day at monthly intervals. The CsA dose associated with the first rise in PASI was regarded as the minimal effective CsA dose. In the event of relapse (PASI above 50\% baseline value) CsA was withdrawn. In any case CsA was withdrawn after 16 months of therapy.

If there was a rise in serum creatinine of more than $30 \%$ over baseline, a rise in serum potassium above the upper limit of the normal range, or a diastolic blood pressure above $95 \mathrm{mmHg}$ at two consecutive visits, CsA was reduced by about $25 \%$. If the abnormality was not corrected within four weeks, a further reduction by $25 \%$ was made.

Whole blood CsA levels were initially checked weekly during the first month of treatment and every 4 weeks thereafter. Trough CsA concentrations $(\mathrm{ng} / \mathrm{ml})$ were measured 12-14 h after the last dose of CsA using a monoclonal antibody RIA-kit (Sandoz Ltd, Basle, Switzerland). Before initiating CSA treatment (baseline $=\mathrm{BL}$ ), after 12 weeks of therapy and 4 weeks after complete withdrawal of CSA, renal function tests were performed using simultaneous determinations of the ${ }^{125}$ I-iothalamate and ${ }^{131} \mathrm{I}$-hippuran clearances for glomerular filtration rate (GFR) and effective renal plasma flow (ERPF), respectively.' 
The GFRs and ERPFs were normalized for body surface area. Clearances were expressed as $\mathrm{ml} / \mathrm{min} / 1.73 \mathrm{~m}^{2}$. The GFR and ERPF were performed at $09.00 \mathrm{a} . \mathrm{m}$. after the patient had fasted for at least $9 \mathrm{~h}$.

Renal blood flow (RBF) was calculated by:

$$
\mathrm{RBF}=\frac{\mathrm{ERPF}}{1 \text {-haematocrit }}
$$

and expressed as $1 / \mathrm{min}$. Blood pressure was measured in a sitting position, after $5 \mathrm{~min}$ rest, using a standard mercury sphygmanometer. Total renal vascular resistance (TRVR) was calculated by:

$$
T R V R=\frac{\text { MAP }}{\text { RBF }} \times 80
$$

and expressed as dyn $\mathrm{s} / \mathrm{cm}^{5}$ (MAP $=$ Mean arterial pressure $=$ diastolic $\mathrm{BP}+$ [pulse pressure/3]). (MAP is expressed in $\mathrm{mmHg}$, RBF in $1 / \mathrm{min}$, in order to express TRVR in dynes.s.cm-5 it is neccesary to multiply MAP/RBF with 80.) Haematological and biochemical measurements were performed using standard laboratory techniques.

\section{STATISTICAL ANALYSIS}

All results are expressed as medians and ranges. For statistical analysis a two-tailed Wilcoxon signed-rank test for paired observations was used. A $P$-level of $<0.05$ was considered significant.

\section{RESULTS}

The results are listed in Table 1. The psoriasis improved considerably in all patients. The patients continued therapy 4-16 months, (median 11.8 months). Only four patients continued therapy for 16 months. The other four patients discontinued therapy earlier because of a relapse in psoriasis, as a result of the reduction in CsA dose. The minimal effective dose was $3.2(2.3-4.2) \mathrm{mg} / \mathrm{kg} /$ day. Four patients had a $25 \%$ dose reduction because of side-effects, mainly a rise in serum creatinine above $30 \%$ of baseline. The renal parameters and mean renal parameters are listed in Tables 2 and 3, respectively. After 12 weeks of therapy we observed, in relation to baseline, a reduction in GFR of $17.8 \%$ (2.2-31.9\%), ERPF $10.1 \%$ (7.4-27.3\%), RBF 6.0\% (4.1-17.5\%) and an increase in TRVR 15\% (NS). There was limited improvement 4 months after withdrawal of CsA, GFR $-9.8 \%$ (5.5-21.5), ERPF -13.5\% (3.0-32.9\%), RBF -7.7\% (1.6-18.1\%) and TRVR $+17 \%(\mathrm{NS})$. 


\begin{tabular}{|c|c|c|c|c|c|c|c|c|c|c|c|c|}
\hline $\begin{array}{l}\text { Pat } \\
\text { no }\end{array}$ & $\begin{array}{l}\text { Age } \\
\text { yrs }\end{array}$ & $\begin{array}{l}\text { PASI } \\
\text { BL }\end{array}$ & $\begin{array}{l}\text { BP } \\
\text { BL }\end{array}$ & $\begin{array}{l}\text { CsA } \\
\text { level }\end{array}$ & $\begin{array}{l}\text { Dose } \\
\text { red. }\end{array}$ & $\begin{array}{l}\text { PASI } \\
\text { red\% }\end{array}$ & $\begin{array}{l}\text { BP } \\
\text { wk12 }\end{array}$ & $\begin{array}{l}\text { CsA } \\
\text { med }\end{array}$ & $\begin{array}{l}\text { CsA } \\
\text { mo. }\end{array}$ & $\begin{array}{l}\text { CsA } \\
\text { dose }\end{array}$ & $\begin{array}{l}\text { CsA } \\
\text { end level }\end{array}$ & $\begin{array}{l}\text { BP } \\
\text { end }\end{array}$ \\
\hline 1 & 33 & 18.7 & $125 / 80$ & 115 & - & 100 & $120 / 80$ & 2.33 & 16 & 2.33 & $<25$ & $120 / 80$ \\
\hline 2 & 34 & 18.0 & $115 / 65$ & 145 & $\mathrm{~K}^{+}$ & 62.2 & $110 / 60$ & 4.05 & 4 & 4.05 & 60 & $115 / 65$ \\
\hline 3 & 25 & 21.0 & $135 / 85$ & 135 & Creat & 92.3 & $130 / 90$ & 3.71 & 8 & 2.66 & 50 & $130 / 90$ \\
\hline 4 & 60 & 18.1 & $135 / 90$ & 115 & - & 90.6 & $140 / 90$ & 2.50 & 16 & 2.50 & 60 & $135 / 90$ \\
\hline 5 & 41 & 20.0 & $130 / 80$ & 120 & - & 83.0 & $125 / 85$ & 2.60 & 16 & 2.60 & 50 & $140 / 90$ \\
\hline 6 & 45 & 20.5 & $120 / 80$ & 135 & Creat & 92.7 & $135 / 95$ & 2.44 & 13 & 2.44 & 40 & $125 / 85$ \\
\hline 7 & 30 & 23.1 & $120 / 70$ & 110 & Creat & 69.0 & $120 / 70$ & 4.25 & 5 & 4.22 & 85 & $120 / 70$ \\
\hline 8 & 44 & 19.0 & $135 / 85$ & 155 & - & 98.9 & $130 / 80$ & 4.30 & 16 & 2.50 & 35 & $135 / 80$ \\
\hline \multicolumn{13}{|c|}{$\begin{array}{l}\text { BL, baseline; BP, bloodpressure (mmHg systolic/diastolic); CsA level, the mean CsA trough blood level ( } \mathrm{gg} / \mathrm{ml} \text { ) during the first } 12 \text { weeks of } \\
\text { treatment; Dose red., dose reductions because of side-effects; PASI red., reduction of PASI at week } 12 \text { in comparison with baseline; CsA mo., } \\
\text { CsA therapy in months until CsA was withdrawn; CsA med, minimal effective dose of CsA (mg/kg/day); CsA dose, CsA dose (mg/kg/day) during } \\
\text { the last month(s) of CsA therapy; CsA end level, the mean CsA trough blood level (ng/ml) in the last month of treatment; BP end, the blood } \\
\text { pressure in the last month of treatment (minHg). }\end{array}$} \\
\hline
\end{tabular}

\begin{tabular}{|c|c|c|c|c|c|c|c|c|c|c|c|c|}
\hline \multirow[b]{2}{*}{$\begin{array}{l}\text { Pat } \\
\text { no }\end{array}$} & \multirow[b]{2}{*}{ Creat } & \multicolumn{4}{|c|}{ Baseline } & \multicolumn{4}{|c|}{ Week 12} & \multicolumn{3}{|c|}{4 months after CsA withdrawal } \\
\hline & & GFR & ERPF & TRVR & Creal & $\begin{array}{l}\text { GFR } \\
\text { red\% }\end{array}$ & $\begin{array}{l}\text { ERPF } \\
\text { red } \mathscr{E}\end{array}$ & $\begin{array}{c}\text { TRVR } \\
\text { o increase }\end{array}$ & Creat & $\begin{array}{l}\text { GFR } \\
\text { red } \%\end{array}$ & $\begin{array}{l}\text { ERPF } \\
\text { red } \%\end{array}$ & $\begin{array}{c}\text { TRVR } \\
\% \text { increase }\end{array}$ \\
\hline 1 & 98 & 91 & 374 & 41.6 & 100 & 2.2 & 5.1 & -1.5 & 100 & +5.5 & 12.8 & 8.1 \\
\hline 2 & 90 & 112 & 522 & 25.1 & 102 & 20.5 & 7.3 & -12.4 & 98 & 21.4 & 23.4 & 7.1 \\
\hline 3 & 77 & 117 & 604 & 24.1 & 100 & 23.9 & 27.3 & 18.0 & 86 & 5.1 & 24.2 & 16.2 \\
\hline 4 & 96 & 83 & 320 & 50.6 & 96 & 10.8 & 3.1 & 1.0 & 99 & 13.3 & 2.5 & -1.2 \\
\hline 5 & 92 & 88 & 368 & 41.3 & 104 & 19.3 & 12.2 & 19.8 & 108 & 19.3 & 32.9 & 52.0 \\
\hline 6 & 95 & 64 & 232 & 41.8 & 105 & 12.5 & +7.4 & 44.0 & 104 & 1.6 & +3.0 & 46.0 \\
\hline 7 & 87 & 116 & 607 & 18.2 & 100 & 31.9 & 18.1 & 48.1 & 96 & 11.2 & 10.7 & 15.3 \\
\hline 8 & 84 & 102 & 428 & 36.8 & 106 & 21.6 & 14.9 & 3.2 & 91 & 11.7 & 4.2 & -8.0 \\
\hline
\end{tabular}




\section{DISCUSSION}

CsA is effective in psoriasis but there appears to be great variability in the minimal effective dose (range 2.33 to $4.25 \mathrm{mg} / \mathrm{kg} / \mathrm{day}$ ). In this study the median minimal effective dose was 3.2 $\mathrm{mg} / \mathrm{kg} /$ day. This is comparable with values reported previously. ${ }^{11,11}$

\author{
Table 3. Mean renal parameters \\ Buseline (BL) Week 12 \\ 4 months after \\ CsA withdrawal \\ Creat $89.9 \quad 102 \quad(p<0.02$ vs BL $)$ \\ 97.8 (NS) \\ GFR 96.6 \\ 78.4 ( $p<0.02 v 8 \mathrm{BL})$ \\ $86.8(\rho<0.05 \mathrm{va} \mathrm{BL})$ \\ ERPF 432 \\ $378(\mathrm{p}<0.05 \mathrm{vs} \mathrm{BL})$ \\ TRVR 34.9 \\ 39.7 (NS) \\ 367 ( $<<0.02$ vs BL) \\ 41.1 (NS)
}

Creat., senum creatinine ( $\mu \mathrm{mol} / /)$; GFR, glomerulur filtration rate (ml/min); ERPF, effoctive remal plasm flow (ml/min); TRVR, total reoovascular resistance $\left(1000 \times \mathrm{dyn} / \mathrm{s} / \mathrm{cm}^{3}\right)$; NS, not significant.

In four patients long-term treatment efficacy was limited by dose reductions necessitated by side-effects. After dose reduction, the psoriasis relapsed. This indicates that the therapeutic window for CsA therapy is small.

It is assumed that after low-dose $\mathrm{CsA}$ therapy for psoriasis all side-effects are reversible. However, few studies have been published in which renal function was studied with adequate GFR and ERPF measurements. Often GFR was measured after 8 or 12 weeks of therapy and not thereafter. ${ }^{12}$ To our knowledge, only one study has been published in which the reversibility of the observed renal impairment in low-dose CsA therapy for psoriasis has been adequately studied. ${ }^{13}$ In this study by Powles et al ${ }^{13}$ it was shown that impairment of renal function is reversible to a large extent after long-term therapy with CsA. However, there were no baseline values for GFR and ERPF available. Therefore, an irreversible component of the renal impairment cannot be reliably excluded in their study design. Irreversible renal damage with long-term low-dose CsA therapy has been reported in patients with conditions other than skin diseases. ${ }^{5,6}$ and morphological renal changes have been observed in psoriasis patients treated with low-dose CsA therapy for 618 months. ${ }^{7}$ Morphological changes were detected in a patient treated with a dose as low as $2.5 \mathrm{mg} / \mathrm{kg} /$ day. $^{?}$

The patients in our study were treated with an initial dose of $5 \mathrm{mg} / \mathrm{kg} /$ day. After week 12 the CsA dose was subsequently reduced until the minimal effective dose was reached, and thereafter the patients were treated with the minimal effective dose of CsA (median 3.2; range $2.33-4.25 \mathrm{mg} / \mathrm{kg} / \mathrm{day}$ ). We found considerable renal impairment, as measured by GFR and ERPF, at week 12. It is possible that, with a lower initial dose of CsA, the renal impairment would have been less. 
Four months after withdrawal of CsA a sustained renal impairment could be demonstrated, in some patients as high as $20 \%$ reduction from baseline value. It is possible that renal function might improve further after this period, but until this has been investigated, CsA should be used with caution in dermatology, particularly as irreversible morphological renal changes have been observed in psoriasis patients.' Functional renal changes should be kept to a minimum. and an increase in serum creatinine to more than $30 \%$ over baseline should not be allowed to occur. ${ }^{14}$

Further studies are warranted, in which the renal side-effects during and after long-term CsA therapy are monitored.

\section{REFERENCES}

1. van Joost Th, Bos JD, Heule F, Meinardi MMHM. Low-dose cyclosporin A in severe psoriasis. A double-blind study. Br \$ Dermatol 1988: 118; 183-190.

2. Eltis CN, Fradin MS, Messana JM, Brown MD, et al. Cyclosporine for plaque-type psoriasis. Results of a multi dose, double blind trial. N Eng I Med 1991; 324: 277-284.

3. de Rie MA, Meinardi MMHM, Bos JD. Analysis of side-effects of medium- and low-dose cyclosporin maintenance therapy in psoriasis. Br J Dermatol 1990; 123: 347-353.

4. Meinardi MMHM, Bos JD. Cyclosporine maintenance therapy in psoriasis. Transpl Proc 1988; vol XX Suppl 4: 42-49.

5. Myers BD, Newton L, Boshkos C, Macoviak JA, et al. Chronic injury of human microvessels with low-dose cyclosporine therapy. Transpl 1988; 46: 694-703.

6. Bertani T, Ferrazzi P. Schieppati A, et al. Nature and extent of glomerular injury induced by cyclosporine in heart transplant patients. Kidney Int 1991; 40: 243-250.

7. Zachariae H, Hansen HE, Kragballe K. Olsen S. Morphological renal changes during cyclosporine treatment of psoriasis. J Am Acad Dermatol 1992; 26: 415-419.

8. Fredriksson T', Pottersson U. Severe psoriasis = oral therapy with a new retinoid. Dermatologica 1978; 157: $238-241$

9. Donker AJM, van der Hem GK, Sluiter WJ, Beekhuis W, A radio isotope method for smultaneous determination of the glomerular filtration rat and the effective renal plasma flow. Netb J Med 1977; 20: 97.103.

10. Griffiths CEM, Powles AV, McFadden J, Baker BS et al. Long-term cyclosporin for psoriasis. Br J Dermatol 1989; 120: 253-260

11. Korstanje MJ, Van de Stank WJBM. Long-term treatment of psoriasis with cyclosporin A, side-effects, minimal effective dose and cyclosporin blood levels. Clin Exp Dermatol 1991; 16: 8-10.

12. Ellis CN, Fradin MS, Massana JM, Brown MD, et al. Cyclosporine for plaque-type psoriasis. Results of a multi dose double-blind trial. N Eng J Med 1991; 324: 277-284.

13. Powles AV, Carmichael D, Hulme B, Thomas $E_{4}$ et al. Renal function after long-term low-dose cyclosporin for psoriasis. Br J Dermatol 1990; 122: 665-669.

14. Mihatsch $M$, Thiel $G$, Ryffel $B$. Hazards of cyclosporin A therapy and recommendation for its use. J Autoimmun 1988; 1: 533-543. 
CHAPTER 4.

\title{
DOES FISH OIL PROTECT RENAL FUNCTION IN
} CYCLOSPORINE-TREATED PSORIASIS PATIENTS?

\author{
T.J.Stoof, M.J.Korstanje, H.J.G.Bilo, Th.M.Starink, \\ R.F.H.J.Hulsmans, A.J.M.Donker, \\ J Intern Med 1989; 226: 437-441.
}

\begin{abstract}
In order to study the influence of fish oil on cyclosporine $A(\mathrm{CsA})$-induced renal dysfunction, 13 patients with psoriasis (CsA group) received CsA alone, and seven patients (CsA/EPA+DHA group) received a combination of cyclosporine $A$ and fish oil $(6 \mathrm{~g}$ eicosapentaenoic acid, C20:5 omega-3, and docosahexaenoic acid, C22:6 omega-3, daily) for 3 months. The glomerular filtration rate fell by $18.0 \pm 9.6 \%$ in the CsA group compared with $8.7 \pm 6.8 \%$ in the $\mathrm{CsA} / \mathrm{EPA}+\mathrm{DHA}$ group (mean $\pm \mathrm{SD}, P<0.05$ ). The effective renal plasma flow fell by $10.6 \pm 8.9 \%$ in the CsA group and did not change in the CsA/EPA+DHA group $(P<0.05)$. The calculated total renal vascular resistance increased by $19.8 \pm 14.5 \%$ in the CsA group and did not change in the CsA/EPA+DHA group $(P<0.01)$. The results of this pilot study suggest that fish oil can reduce CsAassociated renal dysfunction in psoriasis patients.
\end{abstract}




\section{INTRODUCTION}

Cyclosporine A (CsA), a fungal cyclic polypeptide, has been shown to suppress both humoral and cell-mediated immunity by affecting early steps of T-cell activation. ${ }^{1}$ It is one of the most extensively used immunosuppressive drugs in organ transplantation at the present time. ${ }^{2}$ Because of its immunosuppressive effects, CsA has also been used in the treatment of various apparently immune-mediated diseases such as diabetes mellitus, ${ }^{3}$ multiple sclerosis ${ }^{4}$ and others, with a varying degree of success. Recent studies have also shown a remarkable beneficial effect in patients with psoriasis. ${ }^{5,6}$ The mechanism of action of CsA in psoriasis has not been fully elucidated yet. Immunosuppression of primary cytotoxic T-cell responses can play a role.?

One of the major problems limiting a more extensive use of CsA, however, is CsAinduced nephrotoxicity. Recent studies suggest that altered haemodynamics play an important role in CsA-induced renal dysfunction. ${ }^{8}$ Glomerular filtration rate is reduced both in animal experiments 9 and in man ${ }^{10}$ following CsA-administration, probably due to an increased production of thromboxane A2 (TxA2). . Furthermore, histological examination of the kidney after prolonged CsA-treatment reveals tubular damage."

Recently, it has been shown that fish oil, containing high concentrations of the polyunsaturated fatty acids eicosapentaenoic acid (EPA, C20:5 omega-3) and docosahexaenoic acid (DHA, C22:6 omega-3), reduces CyA-nephrotoxicicty in the rat, probably by lowerig the TxA2-production. ${ }^{9,12}$ In addition, fish oil by itself my have a limited beneficial effect on psoriasis as well. ${ }^{13,14}$ These observations prompted us to evaluate the effects of CsA with and without fish oil in patients with severe psoriasis, in particular with respect to renal function.

\section{STUDY POPULATION AND METHODS}

Patients were selected as part of a large multicentre study (Sandoz Ltd, Basle, Switzerland, study OL 8013) to test the efficacy, safety and tolerability of CsA for induction of remission and remission maintenance in severe, recalcitrant plaque form psoriasis. Patients participating in this study were treated using CsA with either 2.5 or $5 \mathrm{mg} / \mathrm{kg} /$ day for 12 weeks.

In a pilot study in two centres (Free University Hospital, Amsterdam, and Academic Hospital, Maastricht), patients were randomized in three groups using CsA with either 2.5 or $5 \mathrm{mg} / \mathrm{kg} /$ day (together group A), or $5 \mathrm{mg} / \mathrm{kg} /$ day combined with $12 \mathrm{~g}$ fish oil 
concentrate daily (group B) for 12 weeks. A total of 18 patients were randomized in group $\mathbf{A}$ and eight patients in group $\mathbf{B}$.

The fish oil concentrate used was Super EPA (Pharmacaps Inc, Marlow, Buckinghamshire, UK). Each capsule of $1000 \mathrm{mg}$ Super EPA provided $300 \mathrm{mg}$ EPA and $200 \mathrm{mg}$ DHA as their ethylesthers, and 1 IU vitamin $\mathrm{E}$, resulting in a daily intake of $6 \mathrm{~g}$ EPA +DHA.

Whole blood CsA levels were initially checked weekly and every fornight after 1 month. Trough CsA concentrations $(\mathrm{ng} / \mathrm{ml}$ ) were measured 12 to $14 \mathrm{~h}$ after the last dose of CsA using a monoclonal antibody RIA-kit (Sandoz Ltd, Basle, Switzerland). When renal function deteriorated (increase in serum creatinine level above $30 \%$ of basline value) or when serum potassium levels rose over $5.5 \mathrm{mmol} /$, the CsA dose was adjusted. The study design was approved by the scientific and ethical committees of the participating hospitals.

Before initiating the CsA treatment (baseline $=\mathrm{BL}$ ) and after 12 weeks of therapy, renal function tests were performed using simultaneous determinations of the ${ }^{125}$ I-iothalamate and ${ }^{131}$ I-hippuran clearances for glomerular filtration rate (GFR) and effective renal plasma flow (ERPF), respectively. ${ }^{\text {is }}$ Clearances were expressed as $\mathrm{ml} / \mathrm{min} 1.73 \mathrm{~m}^{2}$. Renal blood flow (RBF) was calculated by: RBF = ERPF/(1-Ht) and expressed as $1 / \mathrm{min}$. Total renal vascular resistance (TRVR) was calculated by: $T R V R=(M A P / R B F) 80$ and expressed as dynes. $/ \mathrm{cm}^{-5}$. Blood pressure was measured using a standard mercury sphygmomanometer. Haematological and biochemical measurements were performed using standard laboratory techniques.

Since dietary omega-3 fatty acids are incorporated in a dose-dependent manner into plasma phospholipids, ${ }^{16}$ we assessed compliance to the fish oil supplementation by analysis of the fatty acid composition of plasma phospholipids, described previously. ${ }^{17}$

A wide variation in CsA trough concentrations was found in either group. Since a correlation appears to exist between the actual blood CsA concentration and the degree of loss of renal function in the individual patient, only those patients of both groups with nearly identical CsA levels were compared.

In total, seven patients of group B were completely evaluated (CsA/EPA+DHA group)(Table 1). One patient could not be evaluated because of non-compliance. In group A those patients selected had CsA trough levels at the time of the second renal function test comparable with the values found in the CsA/EPA +DHA group. A total of 13 patients of group A qualified for inclusion in the analysis (Table 1). Severity of psoriasis was expressed as PASI-score (=psoriasis area and severity index ${ }^{18}$ ). 


\begin{tabular}{|c|c|c|c|c|c|c|c|c|c|}
\hline \multicolumn{5}{|c|}{ CsA/ERA + DHA group } & \multicolumn{5}{|c|}{ CaA group } \\
\hline $\begin{array}{l}\text { Pat. } \\
\text { no. }\end{array}$ & CaA & PASI & GFR & ERPF & $\begin{array}{l}\text { Pat. } \\
\text { so. }\end{array}$ & $\mathrm{CaA}$ & PASI & GFR & ERPF \\
\hline XIX & 50 & $0 \%$ & $93.7 \%$ & $97.0 \%$ & I & 50 & $9 \%$ & $89.1 \%$ & $96.9 \%$ \\
\hline \multirow[t]{3}{*}{$\mathrm{XX}$} & 82 & $22 \%$ & $100.4 \%$ & $102.3 \%$ & XVIII & 68 & $74 \%$ & $93.2 \%$ & $95.8 \%$ \\
\hline & & & & & VII & 73 & $0 \%$ & $90.2 \%$ & $104.9 \%$ \\
\hline & & & & & XI & 89 & $31 \%$ & $68.3 \%$ & $81.9 \%$ \\
\hline \multirow[t]{3}{*}{ XXI } & 107 & $4 \%$ & $78.0 \%$ & $95.9 \%$ & III & 103 & $59 \%$ & $85.9 \%$ & $82.4 \%$ \\
\hline & & & & & IX & 103 & $8 \%$ & $76.2 \%$ & $81.2 \%$ \\
\hline & & & & & XIV & 110 & $14 \%$ & $82.7 \%$ & $78.7 \%$ \\
\hline XXII & 120 & $8 \%$ & $89.1 \%$ & $97.8 \%$ & VIII & 114 & $0 \%$ & $94.3 \%$ & $105.2 \%$ \\
\hline XXIV & 120 & $39 \%$ & $96.6 \%$ & $88.1 \%$ & IV & 118 & $47 \%$ & $79.0 \%$ & $92.4 \%$ \\
\hline KXVI & 123 & $16 \%$ & $87.0 \%$ & $107.1 \%$ & XII & 123 & $12 \%$ & $82.0 \%$ & $92.1 \%$ \\
\hline \multirow[t]{3}{*}{ xxv } & 145 & $81 \%$ & $93.4 \%$ & $103.2 \%$ & II & 135 & $31 \%$ & $60.1 \%$ & $79.8 \%$ \\
\hline & & & & & XIII & 138 & $8 \%$ & $88.5 \%$ & $88.3 \%$ \\
\hline & & & & & VI & 140 & $11 \%$ & $76.0 \%$ & $82.3 \%$ \\
\hline Meen & 107 & 24 & 91.2 & 98.8 & & 105 & 23 & 82.0 & 89.4 \\
\hline SD & 29 & 28 & 7.3 & 6.2 & & 27 & 23 & 10.0 & 9.3 \\
\hline
\end{tabular}

\section{Statisfical analysis}

All results are expressed as mean \pm standard deviation (SD). Results were analysed using a two-tailed Wilcoxon test for paired observations, and the Mann-Whitney U-test for unpaired observations, where appropriate. A $P$ value of less then 0.05 was considered statistically significant.

\section{RESULTS}

There were no statistically significant differences between the two selected groups with respect to age and sex distribution (group A: age $38 \pm 9$ years, eight men and five women; group B: age $42 \pm 14$ years, five men and two women). Patients in group B were leaner (group A: BMI $=24.0 \pm 3.1 \mathrm{~kg} \mathrm{~m}$; group B: BMI $=21.2 \pm 2.9 \mathrm{~kg} \mathrm{~m}^{2}$, $P<0.05)$. Mean concentrations of CsA in both groups were comparable (105 $\pm 27 \mathrm{ng} / \mathrm{ml}$ in the CsA group and $107 \pm 29 \mathrm{ng} / \mathrm{ml}$ in the CsA/EPA +DHA group). As shown in 
Table 1, the PASIscore in both groups, expressed as a percentage of the baseline value, showed a wide variation without any correlation between CsA levels and PASI-reduction, indicating a strong variability in susceptibility towards CsA in both groups.

No differences in overall PASI-score reduction could be observed between the two groups (Table 1). Mean blood pressure values did not change in both groups ${ }_{\text {n }}$ although it was necessary to start antihypertensive medication in two patients of the CsA group.

In the analysis of the fatty acid composition of the plasma phospholipids, no changes were found between baseline and after 3 months in the CsA group. In the CsA/EPA+DHA group was a significant increase of the concentrations of C20:5 omega-3, C22:5 omega-3 and the C22:6 omega-3, with a concomitant decrease in the concentrations of C18:2 omega-6 (non-significant, $P=0.06$ ) and $C 20: 4$ omega- 6 , indicating a good compliance to the fish oil ingestion (Table 2).

In Table 1, PASI-score is expressed as a percentage of the initial score (initial score valued as $100 \%$ ). GFR and ERPF values are presented, expressed as percentages of baseline values for all patients included. A great variability in susceptibility towards CsAinduced renal; dysfunction appears to exist. However, the mean CsA-induced impairment of the GFR was significantly less in the CsA/EPA+DHA group compared with the CsA group (CsA/EPA+DHA: $-8.7 \pm 6.8 \%$ vs. CsA: $-18.0 \pm 9.6 \%, P<0.05$; Table 3 ). A comparable tendency was found for the ERPF, with a significant fall in the ERPF of the CsA group and no change in the ERPF of the CsA/EPA+DHA group (CsA/EPA+DHA: $-1.2 \pm 5.7 \%$ vs. CsA: $-10.6 \pm 8.9 \%, P<0.05$; Table 3 ). As could be expected with a fall in GFR, serum creatinine levels rose in both groups (CsA/EPA+DHA: $11.8 \pm 10.3 \%$ vs. CsA: $21.5 \pm 26.3 \%$, NS; Table 3 ). In both groups a fall in FF could be observed, although only significantly in the CsA group. Calculated total renal vascular resistance (TRVR) increased by $19.8 \pm 14.5 \%$ in the CsA group, whereas it did not change at all in the CsA/EPA+DHA group: $-1.8 \pm 5.9 \%(P<0.01$, Table 3$)$. 


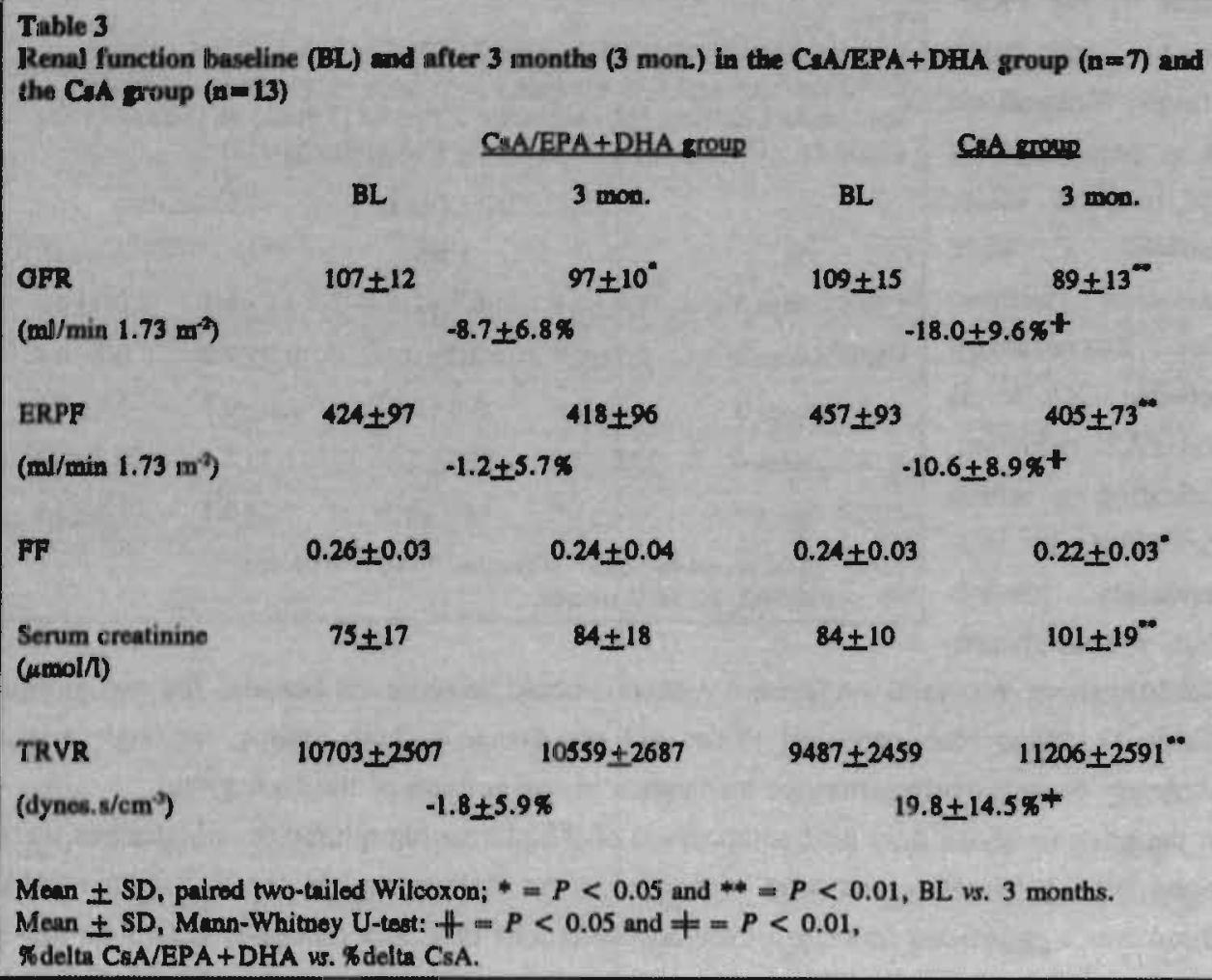

\section{DISCUSSION}

The presented results strongly suggest an attenuation of the CsA-induced acute renal dysfunction by addition of fish oil to the diet of the patient. Our observations are supported by the recent observations of Homan van der Heide et al., ${ }^{19}$ who in a randomized double-blind study in renal transplant recipients observed a $20 \%$ increase in GFR when CsA was combined with fish oil over a period of 12 weeks, at least 6 months after grafting. In that study CsA trough levels remained unchanged, as did the CsA doses during the observation period.

However, a proper interpretation of our results is hampered by the fact that we performed the matching after the study was finished. By including all patients from group $A$ with CsA levels comparable to the CsA levels in group B, we tried to prevent a bias towards a selective choice of patients. Recently, a comparable conclusion was obtained by Elzinga et al. in an experimental rat model. 0.12 In those studies, it was concluded that the beneficial effect of fish oil was mainly due to the intrarenal inhibition of TxA2-production, a potent vasoconstrictor. CsA increases the production of TXA2 in the animal model. 9 
In particular, eicosapentaenoic acid appears to be able to successfully compete with arachidonic acid in the cyclo-oxygenase pathway, thus limiting the production of TxA2. ${ }^{20}$ However, both in the animal model and in our patients complete protection of renal function could not be achieved. Even a complete inhibition of TxA2-production in rats with a thromboxane synthetase inhibitor ${ }^{21}$ did not return GFR to control levels, suggesting that other mechanisms are also involved in the loss renall function induced by CsA. The results of our pilot study strongly suggest that fish oil can favourably modify CsAassociated renal dysfunction in psoriasis patients. Further studies are warranted both to validate and to explain our findings.

\section{REFERENCES}

1. Burchkart J, Guggenheim B. Cyclosporin A: in vivo and in vitro suppression of rat T-lymphocyto function. Immunology 1979; 36: 753-757.

2. Cohen DJ, Loertscher R, Rubin MF et al. Cyclosporine: a new immunosuppressive agent for argan transplantation. Ann Intern Med 1984; 101: 667-682.

3. The Canadian-European Randomized Control Trial Group, Cyclosporin-induced remission of IDDM after early intervention: essociation of 1 year of cyclosporin treatment with enhanced insulin secretion. Diabetes 1988; 27: 1574-1582.

4. Mispelblom Beyer JO, Donker AM, Koetsier JC. Renal function three months after discontinuation of cyclosporine in patients with multiple sclerosis. Kidney Int 1988; 40: S60(A).

5. van Joost TH, Bos JD, Heule F, Meinardi MMHM. Low-dose cyclosporin A in severe psoriasis. A double-blind study. Br J Dermat 1988: 118; 183-190.

6. Ellis CN, Gorsulowsky DC, Hamilton TA. Cyclosporin improves psoriasis in a double-blind study. J Am Med Assoc 1986; 256: 3110-3116.

7. Bunjes D, Hart C, Rollinghoff M, Wagner H. Cyclosporin A mediates immunosuppression of primary cytotoxic T-cell responses by impairing the release of interleukin 1 and interleukin 2 . Eur $\mathrm{J}$ Immunol 1981; 11: 657-661.

8. Murray BM, Paller MS, Ferris TF. Effect of cyclosporin on renal haemodynamics in conscious rats. Kidney Int 1985; 28: 767-774.

9. Elzinga L, Kelley VE, Houghton DC, Bennett WM. Fish oil vehicle for cyclosporin lowers renal thromboxanes and reduces experimental nephrotoxicity. Transpl Proc 1987; XIX (1): 1403-1406.

10. Dieperink H, Lessac PP, Kemp E et al. Nephrotoxicity of cyclosporin A in humans: effects on glomerular filtration and tubular reabsorption rates.

Eur J Clin Invest 1987; 17: 493-496.

11. Mihatsch MJ, Theil G, Basler V et al. Morphological patterns in cyclosporin-treated renal transplant recipients. Transpl Proc 1985; XVII (suppl. 1): 101-116.

12. Elzinga L, Kelley VE, Houghton DC, Bennett WM. Modification of experimental nephrotoxicity with fish oil as the vehicle for cyclosporin. Transplantation 1987; 43: 271-274.

13. Bittiner SB, Tucker WFG, Cartwright I, Bleehen SS. A double-blind, randomized, placebo-controlled trial of fish oil in psoriasis. Lancet 1988; i: 378-380.

14. Kettler AH, Baughn RE, Orengo IF et al. The effect of dietary fish oil supplementation on psoriasis. J Am Acad Dermatol 1988; 18: 1267-1273.

15. Donker AJM, van der Hem GK, Sluiter WJ, Beekhuis W. A radio-isotope method for simultaneous determination of the glomerular filtration rate and the effective renal plasma flow. Neth J Med 1977; 20: $97-103$.

16. Bronsgeest-Schoute HC, van Gent CM, Luten JB, Ruiter A. The effect of various intakes of omega-3 fatty acids on the blood lipid composition in healthy buman subjects. Am J Clin Nutr 1981; 34: 17521757.

17. Popp-Snijders C, Schouten JA, de Jong AP, van der Veen EA. Effect of dietary cod-liver oil on the lipid composition of human erythrocyt membranes. Scand J Clin Lab Invest 1984; 44: 39-46. 
18. Frederiksson T, Petterson V. Severe psoriasis; onl therapy with a new retinoid. Dermatologica 1978; 157: 238-244.

19. Homan van der Heide JJ, Bilo HJG, Tegzess AM, Donker NM. Omega 3 polyunsaturated fatty acids improve renal function in renal tmnsplant recipients treated with cyclosporin-A. Kidney Int 1989; 35: $516(A)$.

20. Hamberg $M$. Transformations of 5,8,11,17-eicosapentaenoic scid in human platelets. Biochim Biophys Actu 1980; 618: 389-398.

21. Perico N, Benigna A, Zoja C, Delaini F, et al. Functional significance of exaggerated renal thromboxane A2 synthesis induced by cyclosporine A. Am J Physiol 1986; 251: F581-F587. 


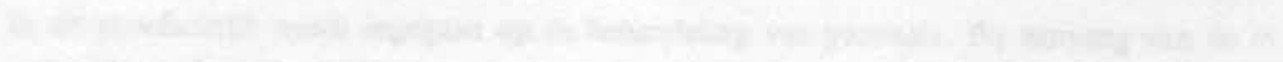

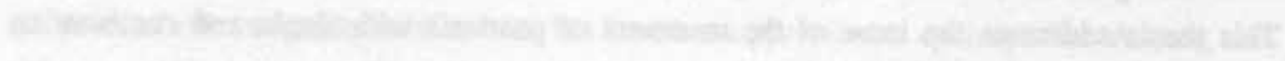

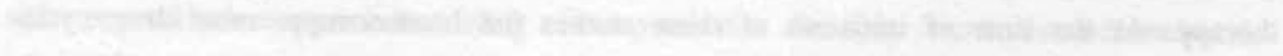

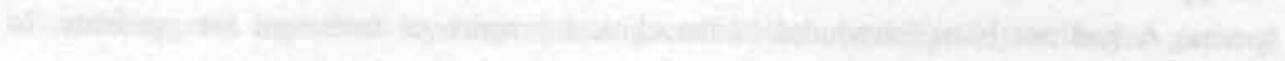

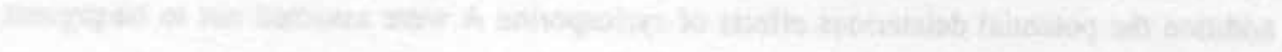

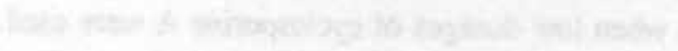

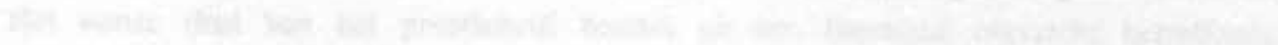

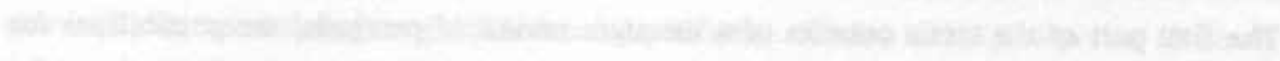

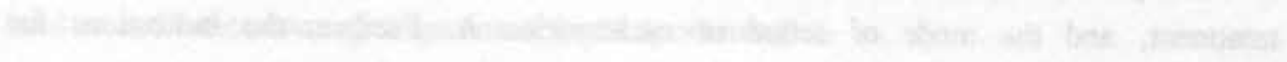

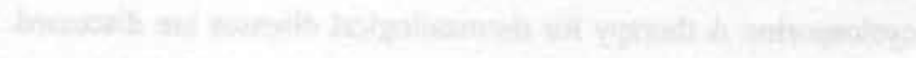

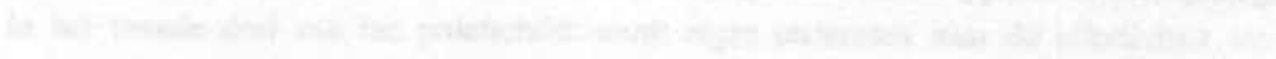

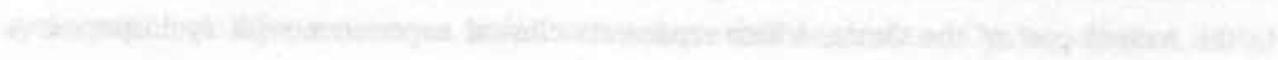

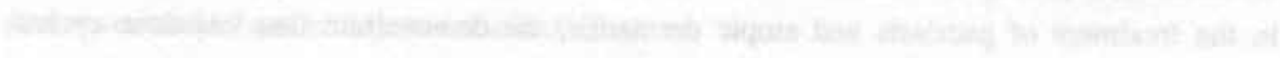

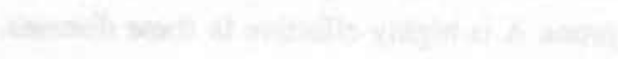

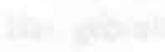

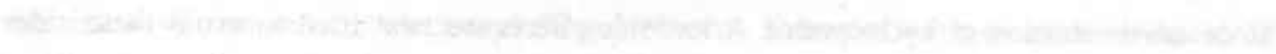

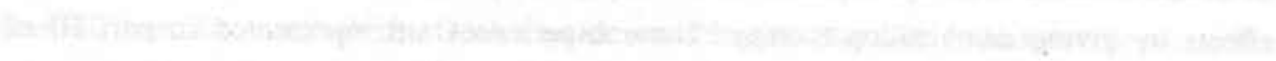

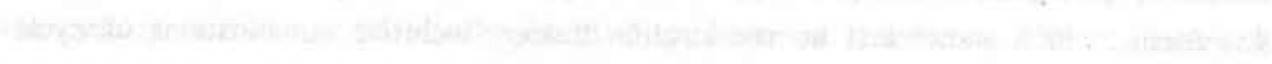

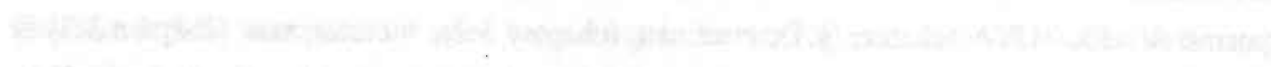
the

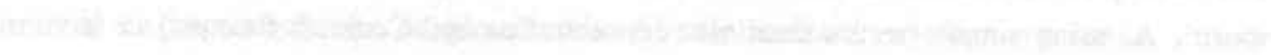

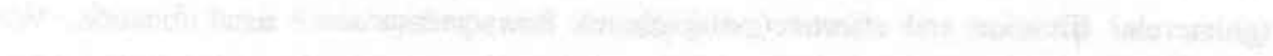

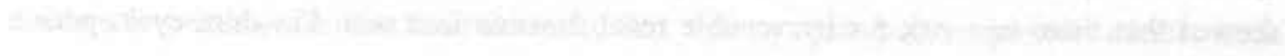

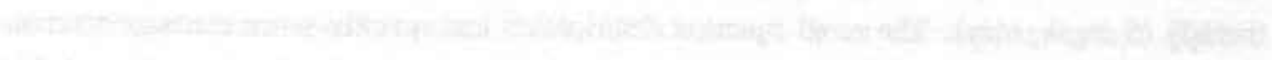

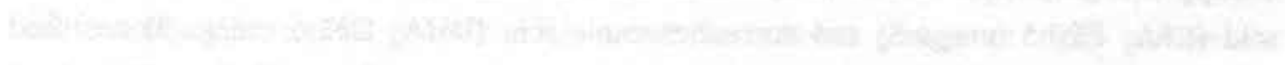

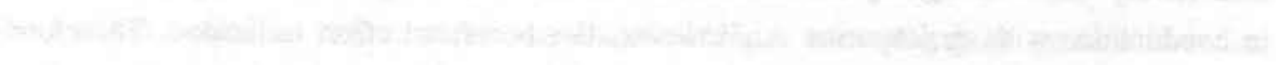

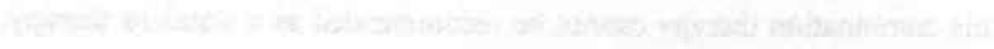




\section{SUMMARY}

This thesis addresses the issue of the treatment of psoriasis with single and combination therapy. At the time of initiation of these studies the immunosuppressive drug cyclosporine A had not been introduced in the clinical practice of treatment for psoriasis. In addition the potential deleterious effects of cyclosporine $\mathrm{A}$ were assumed not to be present when low dosages of cyclosporine $A$ were used.

The first part of the thesis consists of a literature review of psoriasis, the possibilities for treatment, and the mode of action of cyclosporine A. Further, the indications for cyclosporine A therapy for dermatological diseases are discussed.

In the second part of the thesis, which represents clinical experience with cyclosporine A in the treatment of psoriasis and atopic dermatitis, we demonstrate that low-dose cyclosprone $\mathrm{A}$ is highly effective in these diseases.

Since administration of cyclosporine A has side-effects we next tried to avoid these sideeffects by giving combination therapy. These experiences are represented in part III of this thesis, which shows that no combination therapy inclusive combinations of cyclosporine A with PUVA (chapter 3.1), etretinate (chapter 3.2), methotrexate (chapter 3.3) is suitable for long-term treatment of severe psoriasis because of side-effects or ineffectiveness.

The final part of this thesis (Part IV) deals with the nephrotoxic side-effects of cyclosporine $A$, using simple (serum creatinine concentration and Cockroft formula) or isoteric (glomerular filtration and effective renal plasma flow) measures of renal function. We showed that there is a risk for irreversible renal function loss with low-dose cyclosporine therapy $(5 \mathrm{mg} / \mathrm{kg} / \mathrm{day})$. The renal function deteriorates less quickly when eicosapentaenoic acid (EPA, C20:5 omega-3) and docosahexaenoic acid (DHA, C22:6 omega-3) are used in combination with cyclosporine A. However, this beneficial effect is limited. Therefore, this combination therapy cannot be recommended as a standard therapy. 


\section{SAMENVATTING}

In dit proefschrift wordt ingegaan op de behandeling van psoriasis. Bij aanvang van de in dit proefschrift vermelde studies was het immunosuppressivum cyclosporine $A$, nog niet niet beschikbaar voor behandeling van psoriasis. Destijds werd verondersteld dat behandeling met lage dosis cyclosporine A geen of slechts geringe bijwerkingen gepaard zou gaan.

Het eerste deel van het proefschrift bestaat uit een literatuur overzicht betreffende psoriasis, de behandelingsmogelijkheden bij psoriasis, effecten van cyclosporine $\mathrm{A}$ in de huid en indicaties voor cyclosporine $\mathrm{A}$ in de dermatologie.

In het tweede deel van het proefschrift wordt eigen onderzoek naar de effectiviteit van cyclosporine A bij psoriasis en constitutioneel eczeern besproken. Cyclosporine A is bij deze twee ziektebeelden bijzonder effectief.

Het gebruik van cyclosporine A wordt geremd door bijwerkingen. Om bijwerkingen te vermijden werden combinatietherapieên geprobeerd. Deze bevindingen staan vermeld in deel III van dit proefschrift. Geen van de combinatietherapieën waaronder combinaties van cyclosporine A met PUVA (hoofdstuk 3.1), etretinaat (hoofdstuk 3.2), methotrexaat (hoofdstuk 3.3) was geschikt voor toepassing in de praktijk, in verband met bijwerkingen of ineffectiviteit.

Het laatste deel van het proefschrift (Deel IV) behandeld het door cyclosporine A geinduceerde nierfunctieverlies, gebruik makend van serum kreatinine, de Cockroft formule en bepalingen van de glomerulaire filtratie snelheid en effectieve renale plasma flow. Ook bij lage dosis cyclosporine $(5 \mathrm{mg} / \mathrm{kg} / \mathrm{dag})$ bestaat een risico op irreversibel nierfunctie verlies. De nierfunctie verslechtert tijdens cyclosporine gebruik minder snel wanneer tevens eicosapentaeenzuur (EPA, C20:5 omega-3) en docosahexaeenzuur (DHA, C22:6 omega-3) worden gebruikt. Het effect is evenwel gering en deze combinatie therapie kan daarom nog niet als standaard therapie voor dagelijks gebruik worden geadviseerd. 


\section{NAWOORD}

Een proefschrift kan alleen tot stand komen wanneer men voldoende gelegenheid krijgt voor het uitvoeren van het noodzakelijke onderzoek. Bij uitvoeren van klinisch onderzoek is men bovendien afhankelijk van het aanbod aan patienten die bereid zijn aan het betreffende onderzoek deel te nemen. Een proefschrift is daarom zelden het werk van één persoon, velen helpen mee bij het recruteren van patienten en bij het creeren van voldoende tijd en gelegenheid voor uitvoering van het onderzoek.

Ik wil dan ook al diegenen bedanken die de verwezenlijking van dit proefschrift voor mij mogelijk hebben gemaakt. Met name wil ik mijn dankwoord richten tot;

Tom Stoof en Henk Bilo, die mij in het door hen geinitieerde onderzoek naar de combinatie cyclosporine-visolie betrokken. Dit was de aanzet voor mijn proefschrift. Bij het opzetten en uitvoeren van de voor mijn proefschrift noodzakelijke studies hebben zij mij met raad en daad bijgestaan. Bij het verwerken van data en voor begeleiding bij publicaties is de steun van Henk Bilo van onschatbare waarde geweest.

Theo Starink die geheel belangeloos, samen met Tom Stoof, het in het AZVU geinitieerde visolie onderzoek aan mij ter uitvoering en publicatie overliet, heeft hiermee de basis voor mijn proefschrift gelegd. Uitvoering van volgend onderzoek werd door hem ondersteund en als promotor heeft hij door het geven van nuttige aanwijzingen en adviezen geholpen om mijn proefschrift vorm te geven.

Wim van de Staak, mijn opleider in de dermatologie, heeft ervoor gezorgd dat ik mij kon specialiseren tot dermatoloog waarmee ik in de gelegenheid kwam om onderzoek op het gebied van de dermatologie te doen. Hij heeft mij op het eind van de opleidingstijd geholpen om het nog lopende onderzoek ten spoedigste op een voor mij zo voordelig mogelijke wijze te volbrengen.

Martino Neumann, en Peter van Breda-Vriesman wiens adviezen en ondersteuning van essentieel en doorslaggevend belang zijn geweest bij het voltooien van dit proefschrift

Martin Go, Michette de Rooy en Jan Wuite, die mij vanuit hun kliniek in Heerlen regelmatig patienten stuurden om aan mijn studies deel te nemen hebben hiermee voor een groot deel zorg gedragen voor het bijeenbrengen van mijn patienten materiaal. 
Dr.J.J.Homan van der Heide voor het belangeloos aan mij en Henk Bilo ter beschikking stellen van data betreffende niertransplantatie patienten. Hiermee kon het laatste nog te schrijven hoofdstuk van mijn proefschrift worden afgerond. Hij heeft hiermee de voltooiing van dit proefschrift mogelijk gemaakt.

Leontine van Weersch-Rietjens, Joep Veraant, Fierre van Neer, Joost van de Kley, Koos Sanders en Kees-Peter de Roos hebben mij regelmatig patienten toegestuurd en zij hebben mij op de polikliniek de benodigde ondersteuning en gelegenheid gegeven om mijn studies uit te voeren.

De heer Piet Willemz die altijd goed gehumeurd op de afdeling Nucleaire Geneeskunde de uitvoering van GFR/ERPF op zich nam en bovendien de gegevens fraai tabelleerde wil ik bedanken voor zijn nimmer aflatende inzet en energie. De wijze waarop hij telkens weer cen opslagplaatsje voor urine of serum monsters wist te vinden was zeker bewonderenswaardig.

Bep van Toledo en Ingrid Janssen die voor mij en mijn promotor de procedure van de promotie hebben uitgezocht en de noodzakelijke organistatie en correspondentie hebben verzorgd. 


\section{CURRICULUM VITAE}

De schrijver van dit proefschrift werd op 7 juli 1959 in Goes geboren. Na het doorlopen van het VWO-b aan het Goese Lyceum ging hij studeren aan de Rijksuniversiteit Utrecht. $\mathrm{Na}$ een propedeusejaar in de diergeneeskunde studeerde hij van 1978 tot 1985 geneeskunde, waarna hij, in afwachting van cen verdere specialisatie, als AGNIO voor de maatschap dermatologie in het Catharina ziekenhuis te Eindhoven ging werken. Na enkele maanden verhuisde hij naar Amsterdam om in het Academisch Ziekenhuis der Vrije Universiteit een opleiding tot internist te volgen, maar besloot in 1987 om deze opleiding te verruilen voor een opleiding in de dermatologie te Maastricht. Tijdens de opleiding tot dermatoloog heeft hij zitting gehad in het bestuur van de Vereniging Assistenten Dermatologie en Venereologie en werd uiteindelijk in 1990 voorzitter van deze vereniging. Tevens heeft hij namens de assistenten zitting gehad in het Concilium Dermato-venereologicum en heeft hij te Heelsum het eerste landelijke symposium voor assistenten in de dermatovenereologie georganiseerd.

In oktober 1990 vertrok hij naar de afdeling dermatologie van The University Hospital of Wales in Cardiff U.K. om daar, in de vorm van een wetenschappelijk stage, de laatste vier maanden van zijn opleiding in de dermatologic af te ronden en een functie als Clinical Research Officer te aanvaarden.

In september 1991 werd hij, in het Academisch Ziekenhuis Leiden, benoemd tot staflid in tijdelijke dienst verbonden aan de afdeling dermatologie.

De in dit proefschrift beschreven studies zijn tijdens de opleidingsperiode in Maastricht, in samenwerking met de afdeling dermatologie van het Academisch Ziekenhuis der Vrije Universiteit, uitgevoerd. 


\section{FURTHER PUBLICATIONS}

Korstanje MJ, Besserns PJMJ, van de Staak WJBM. Huidafwijkingen bij diabetes. Modern Medicine 1988; 10: 1189-1191

Korstanje MJ, van de Staak WJBM. De diabetische voet. Patient Care 1989; 16: 9-21.

Korstanje MJ, Hulsmans RFHJ, Vissers-Croughs KJM, Jagtman BA. Bilaterale lineaire frontopariêtale sclerodermie 'en coup de sabre'. Ned Tijdschr Geneeskd 1989; 133: 1622.

Korstanje MJ, Hulsmans RFHJ, van der Kley AMJ. Dowling-Degos disease associated with profuse lentigines. Br J Derrnatol 1989; 121: 529-530.

M.J.Korstanje, P.J.M.J.Bessems, W.J.B.M. van de Staak. Combination therapy ciclosporin-etretinate effective in erythrodermic psoriasis. Dermatologica 1989; 179: 94.

M.J.Korstanje. Permanent renal impairment after treatment with ciclosporin.

Dermatologica 1989; 179: 53-54.

Korstanje MJ, Bessems PJMJ, Hardy E, van de Staak WJBM. Delayed-type hypersensitivity reaction to heparin. Contact Dermatitis $1989 ; 20$ : 383-384

Korstanje MJ, van de Staak WJBM. A case of hand eczema due to mushrooms. Contact Dermatitis 1990; 22: 115-116.

Korstanje MJ, van de Staak WJBM. Huidlaesies bij diabetes mellitus. In J.C.van Es, E.Mandema, G.Olthuis, M.Verstraete. Het Medisch Jaar 1990. Bohn Scheltema \& Holkema, Utrecht 1990 pp 370-378.

Korstanje MJ, Neumann HAM. Compressietherapie door middel van elastische kousen. Ned Tijdschr Geneesk 1990; 134: 799-802.

Hulsmans RFHJ, Baeten CGMI, Dunselman GAJ, van der Drift H, Korstanje MJ, et al. HPV-induzierte (Prä-)Kanzerosen im Anogenitalbereich. In Th.Hager, J.Meier zu Eissen, H.Mlitz. Aktuelle Koloproktologie Band 7. Nymphenburg-München 1990 pp 111-128. 
Stoof TJ, Korstanje MJ, Bilo HJG. Does fish oil protect renal function in cyclosporintreated psoriasis patients? Br J Dermatol 1990; 123: 535.

Korstanje MJ, van de Staak WJBM. High cumulative dose of ultraviolet radiation is a contraindication for cyclosporin therapy. Dermatologica 1990; 5: 76.

Korstanje MJ, Bessems PJMJ. Incontinentia Pigmenti and persistent hyperkeratotic lesions in adulthood and possible squamous cell carcinoma. Dermatologica 1991; 183: 234-236.

Korstanje MJ, Bilo HJG, Peltenburg HG, Stoof TJ. Visolie; van voeding tot medicijn? Ned Tijdschr Geneeskd 1991; 135: 828-833.

Korstanje MJ, van de Staak WJBM. Therapeutische mogelijkheden bij psoriasis. Patient Care 1991;18:9-21.

Korstanje MJ, Bilo HJG, Stoof TJ. Kunnen de bijwerkingen van cyclosporine bij de behandeling van psoriasis voorkomen worden? Ned Tijdschr Dermatol Venereol 1991; 1: 104- 110 .

Korstanje MJ, Stoof TJ. Kan het nierfunctie verlies tijdens ciclosporine gebruik gunstig worden beinvloed? Ned Tijdsch Derm Venereol 1992; 2: 35-36.

Yamamoto K, Korstanje MJ. Eczema in childhood. In R.Marks, Eczema, Martin Dunitz 1992 pp 239-254.

Bouwes Bavinck JN, Wolterbeek R, Korstanje MJ, Vermeer BJ. Kans op huidkanker bij de behandeling van psoriasis met ciclosporine. Ned Tijdschr Derm venereol 1992; 2: $171-173$.

Korstanje MJ. How to improve the risk-benefit ratio of cyclosporine therapy for psoriasis. Clin Exp Dermatol 1992; 17: 16-19

Korstanje MJ, Pavel S. Contactovergevoeligheid voor corticosteroiden. Ned Tijdschr Geneeskd 1992; 136: 1440-1442. 


$$
\text { , }
$$


